Portland State University

PDXScholar

Spring 6-13-2019

\title{
Confronting Noh Demons: Zeami's Demon Pacifying Noh and Nobumitsu's Demon Killing Noh
}

Jitsuya Nishiyama

Portland State University

Follow this and additional works at: https://pdxscholar.library.pdx.edu/open_access_etds

Part of the Japanese Studies Commons

Let us know how access to this document benefits you.

\section{Recommended Citation}

Nishiyama, Jitsuya, "Confronting Noh Demons: Zeami's Demon Pacifying Noh and Nobumitsu's Demon Killing Noh" (2019). Dissertations and Theses. Paper 5132.

https://doi.org/10.15760/etd.7011

This Thesis is brought to you for free and open access. It has been accepted for inclusion in Dissertations and Theses by an authorized administrator of PDXScholar. Please contact us if we can make this document more accessible: pdxscholar@pdx.edu. 


\title{
Confronting Noh Demons:
}

Zeami's Demon Pacifying Noh and Nobumitsu's Demon Killing Noh

\author{
by
}

Jitsuya Nishiyama

A thesis submitted in partial fulfillment of the requirements for the degree of

\author{
Master of Arts \\ in \\ Japanese
}

Thesis Committee:

Laurence Kominz, Chair

Jon Holt

Suwako Watanabe

Portland State University

2019 
(C) 2019 Jitsuya Nishiyama 


\begin{abstract}
Noh is often described as a drama of the exploration of the soul. This focus on the human soul is largely attributed to Zeami Motokiyo 世阿弥元清 (c. 1363-c. 1443), the greatest playwright in the history of noh drama. This thesis, however, attempts a more comprehensive examination of the characteristics of noh plays by including works by Kanze Nobumitsu 観世信光 (1435-1516). Zeami and Nobumitsu wrote several demon noh plays, which are plays whose primary characters are demons. There are significant differences in characterization and dramaturgy between Zeami's demon noh in the early Muromachi period, the era of noh's founding, and Nobumitsu's onitaiji-mono noh (鬼退 治物, demon killing noh) in the late Muromachi period, two generations later. In this thesis, I analyze three works by each of those two eminent noh playwrights in order to identify similarities and differences among their works and to compare their styles, structure, theatrical conventions, and use of literary sources. Each of these playwrights represents his era in Japanese literary and political history. By examining socio-cultural aspects of these plays, this thesis will illuminate the changes in Japan's core values over a span of two generations.
\end{abstract}

Nobumitsu's demon noh plays represent these shifting core values among his patrons who were, like Zeami's, comprised of samurai elites. The social ethos of unification and inclusion in the cultural circle of shōgun Ashikaga Yoshimitsu (13581408) significantly impacted Zeami’s plays. For his patrons like Yoshimitsu, the integration of the aristocratic aesthetics into his plays was essential. Zeami emphasized aristocratic beauty, mysterious gracefulness (yūgen), spiritual salvation, and the Zen 
Buddhist tenets of non-duality, creating complex, humanized demon characters.

However, the warrior elite changed significantly in two generations. Nobumitsu's major patrons were powerful warlords during the period when private ambition and revenge prevailed among the samurai and political and military authority was much more fluid than in Zeami's era. For Nobumitsu's patrons, samurai's bravery and resourcefulness were crucial. His waki warrior heroes engage in spectacular combat on stage, fighting and killing powerful, evil demons and kill them. Regional warlords presented these plays to impress their allies, rivals, and their own retainers to expand their prestige in the age of chaos.

New developments in Nobumitsu's noh, make his plays more kabuki-like than Zeami's noh had been. Later forms of theater, kabuki and puppet theater (ningyō jōruri) assimilated noh's aesthetics by adapting some noh and kyōgen plays throughout its history. Noh drama provided compelling characters and fictional worlds for a variety of plays in kabuki and puppet theater. As early as the mid-Muromachi period, Zeami created humanized demon characters which later playwrights of later genres appropriated for their plays. Nobumitsu created spectacular stage which re-shaped theater and prepared the way for later developments of kabuki and puppet theater in Edo period (1600-1868). 


\section{Acknowledgements}

Many individuals provided invaluable support throughout my time as a graduate student in the Department of World Languages and Literatures at Portland State University. I would like to express my deepest gratitude to my advisor, Laurence Kominz, for his insightful advice, stimulating conversations about Japanese culture and literature, and unparalleled enthusiasm for Japanese drama. I would also like to thank the other members of my defense committee, Professors Jon Holt and Suwako Watanabe, for their valuable suggestions and corrections. Professor Holt's love for Japanese poetry inspired me and his courses prepared me to conduct textual analysis in this thesis. Professor Suwako Watanabe's depth of knowledge about Japanese language helped me understand nuances while reading noh texts, as well as in teaching language courses.

The Department of World Languages and Literatures generously supported me with a Graduate Assistantship, and by providing travel grants for presenting my papers at conferences. In my work as a teaching assistant, Professor Karen Curtin and other fellow instructors supported me enormously. Finally, I want to express a special thanks to my father and mother who provided me opportunities to appreciate the performing arts. Without the support from these individuals and the Department of World Languages and Literatures, I could not have completed this thesis. 


\section{Table of Contents}

Abstract $\quad$ i

Acknowledgements $\quad$ iii

List of Tables $\quad$ V

Chapter 1: Zeami, Nobumitsu, and Their Demon Noh 1

Chapter 2: Zeami and Nobumitsu: Changing Social Values and Aesthetics in the 29 Muromachi Samurai Elites

Chapter 3: Crafting Play Scripts for Demon Noh 52

Chapter 4: Directions, Music, Dances, and Staging Conventions 103

$\begin{array}{ll}\text { Conclusion } & 145\end{array}$

$\begin{array}{ll}\text { Works Cited } & 165\end{array}$

Appendix A: Images of Demons and Monsters 168

Appendix B: Masks, Costumes, and Musicians 170 


\section{List of Tables}

$\begin{array}{lll}\text { No. } & \text { Title } & 69 \\ 1 & \text { Dan Sections in Yamanba } & 73 \\ 2 & \text { Dan Sections in Nue } & 74 \\ 3 & \text { Dan Sections in Ukai } & 76 \\ 4 & \text { Dan Sections in Momijigari } & 78 \\ 5 & \text { Dan Sections in Rashömon } & 79 \\ 6 & \text { Dan Sections in Orochi } & 128 \\ 7 & \text { Excerpt of Dan Sections in Yamanba } & 131 \\ 8 & \text { Excerpt of Dan Sections in Ukai } & 133 \\ 9 & \text { Excerpt of Dan Sections in Momijigari } & \end{array}$


Chapter 1: Zeami, Nobumitsu, and Their Demon Noh

Noh 能, or nohgaku 能楽, is the oldest form of Japanese drama dating from the mid-1300s and it is still regularly performed today. ${ }^{1}$ Almost all the important conventions of the noh theater were established by Zeami Motokiyo 世阿弥元清 (c. 1363-c. 1443), ${ }^{2}$ the most influential playwright, performer, and theorist. Zeami wrote over fifty noh plays and twenty-one noh treatises. ${ }^{3}$ Another major noh playwright is Kanze Nobumitsu 観世 信光 (1435-1516), ${ }^{4}$ who refined and developed a new kind of noh play-spectacle $n o h$ play (furyū noh) — in the late Muromachi period. ${ }^{5}$ Both these playwrights wrote several popular, and important demon noh plays. Nobumitsu wrote approximately thirty plays. ${ }^{6}$ Demon noh is a noh play whose primary character is a demon. Among the five categories of noh plays, demon noh has a special position in performance and history because it has usually been performed last in the program and concludes the performance day.

Demons in this paper specifically refer to Japanese demons, called oni 鬼. For contemporary Japanese audiences, the representation of oni in noh plays is perplexing. This confusion is because the modern concept of oni is clearly divergent from that of Japan's archaic and medieval periods (700s to 1500s). The stereotypical demons in modern Japan are human-like creatures with one or more horns on their heads and red,

\footnotetext{
${ }^{1}$ Also known as $n \bar{o}$.

${ }^{2}$ Omote and Amano, Nōgaku no Rekishi, p. 42.

${ }^{3}$ Omote and Amano, Nōgaku no Rekishi, pp. 50-52.

${ }^{4}$ According to noh scholar Omote Akira, his birth year is fifteen years later than the year written in his biography. Even though this adjustment creates a significant difference to examine his artistic development according to his career, this study does not necessarily trace his life career development. No clear evidence has been recorded either, and it is still under the scholarly discussion. Thus, in my thesis, I follow the conventional record for his life. For a summary of Omote's discourse, see Lim, pp. 31-32.

${ }^{5}$ Matsuoka, Nō: Chüsei kara no Hibiki, pp. 66-67, and Lim, p. 53.

${ }^{6}$ Omote and Amano, Nōgaku no Rekishi, pp. 69-70.
} 
blue, or black skin wearing short pants made of tiger skin, and equipped with spiked iron clubs. ${ }^{7}$ They typically harm humans and their property. According to cultural anthropologist Komatsu Kazuhiko, this stereotypical image of demons in the modern age was formed in the Edo period. ${ }^{8}$ He states that present-day Japanese distinguish demons from other creatures by the horns on their heads.

Demon noh plays do not include these stereotypical modern demons. Instead, there are different varieties of demons. One of the unmistakable examples is Yamata no Orochi, a famous mythical serpent monster from Japan's oldest mythology Kojiki (古事 記) and Nihon Shoki (日本書紀, The Chronicles of Japan). Yamata no Orochi is a gargantuan snake, whose length is longer than eight mountains and eight valleys. It has one trunk, but eight heads and eight tails. On its back, cedar and cypress grow. ${ }^{9}$ This "demon" does not have any of a modern demon's features. Because the modern stereotypical demon and this serpent monster are very different, people in present-day Japan never refer to this giant serpent monster as a demon. ${ }^{10}$ Demon $n o h$ plays by Zeami and Nobumitsu portray a variety of monsters including Yamata no Orochi. This rich world of diverse demons is what Zeami and Nobumitsu presented in their plays.

In their demon plays, each of these playwrights represents his era in Japanese literary and political history. By examining these plays in their socio-cultural contexts, this thesis will illuminate the changes in Japan's core values over a span of two

\footnotetext{
${ }^{7}$ For an illustration of this modern stereotypical demon, see Figure 1 in Appendix A.

${ }^{8}$ Komatsu, Oni to Nihonjin, p. 6.

9 “Shindai Jo," Nihonshoki, I: pp. 92-93.

${ }^{10}$ For images of a stereotypical demon and Yamata no Orochi, see Figure 1 and 2 in Appendix A.
} 
generations. The most important patrons of both Zeami and Nobumitsu were samurai

elites. However, the socio-cultural core values of these elites changed significantly in two generations. I also show that new developments in Nobumitsu's noh, make his plays more kabuki-like than Zeami's noh was. As early as the Sengoku period, Nobumitsu was re-shaping theater and preparing Japanese theater to plant the seeds of Edo period (16001868) kabuki theater.

Noh Play Categorization and Demon Noh in Zeami's Treatises

To classify noh plays, noh practitioners and scholars now use five categoriesgod noh, warrior noh, woman noh, miscellaneous noh, demon noh. These categories are classified depending on the leading character of a play. These categories are important because each play is performed to fit into the overall structure of a day-long program. All the plays in the same category function in a similar way to contribute to the progress of one-day performance ${ }^{11}$ even though each play has a different storyline. Although the five categories are standardized and recognized today, it is not clear in the history of noh precisely when this official categorization was established.

Noh's official categorization was carried out sometime in the early Edo period ${ }^{12}$, and demon noh plays were listed as the fifth and last category of the five categories. Two major unifiers of Japan in the late 1500s, Toyotomi Hideyoshi and Tokugawa Ieyasu were great patrons of the noh. After the establishment of the Tokugawa Bakufu by

\footnotetext{
11 Today very few programs are so long as to present five noh plays. Usually, one-three plays are presented. ${ }^{12}$ Yokomichi, Koyama and Omote, Nō no Kōzō to Gihō, p. 22. Omote and Amano, Nōgaku no Rekishi, pp. 90-109.
} 
Ieyasu, the government created the program format (bangumidate 番組立) for performance presentations. The government officials designated noh plays as their official entertainment and social ritual (shikigaku 式楽).

This government designation is the origin of the official six-performance categorization of the noh that the scholars, as well as noh practitioners, use today. ${ }^{13}$ An official program starts the performance with ritual singing and dance piece Okina (翁, Elderly Male God), followed by one play from each of the five categories. The first category is god plays (kami mono 神物), also called supporting plays (waki mono 脇 物). ${ }^{14}$ The second is warrior plays (shura mono 修羅物). The third is wig plays (kazura mono 鬘物), also called woman play (onna mono 女物). The fourth is miscellaneous plays (zatsu mono 雑物). This category includes all the plays which do not belong to other categories. The fifth is demon play (oni mono 鬼物), also called last play (kirinō mono 切能物) - concluding noh plays because they conclude the program of a performance day. According to this format, all the noh plays have their assigned categories without any exceptions. The category for the same play is generally consistent among schools although some have different assignments of categories and some plays belong to two categories.

\footnotetext{
${ }^{13}$ Okina (翁) is an auspicious ritual performance, highly exalted by noh actors. This performance is not considered to be a noh play and not included in any of noh's five categories. Okina is an independent category of performance and consists of only one work. It is not common today to follow the six-play official program created by the Tokugawa Shogunate since it gets too long for modern audiences. See Yokomichi et al, Nō no Kōzō to Gihō, pp. 22-24. However, there still are some surviving traditions such as Itsukushima Shrine's festival noh performances, where they perform five plays each day for three days.

${ }^{14}$ Supporting plays (waki mono) are plays, in which a god is the leading character and follows after the first ritual dance and singing, Okina, in the official program format.
} 
In the Muromachi period, even though official categories did not exist, the two playwrights Zeami and Nobumitsu thought about different categories of plays as we can see in Zeami's treatises. ${ }^{15}$ Zeami, in his treatise "Kashū no Uchi Nukigaki," wrote about how to compose and perform according to the different categories of play. ${ }^{16}$ We can see which plays Zeami considered to be demon noh plays in this treatise. Zeami wrote how the actor should perform in the demon noh play Ukai. He categorized demonic dances into two categories: rikido fū 力動風, in which actors dance with powerful and boisterous movements, and saido fju 砕動風, in which actors make rapid but subtle movements while retaining human interiority. ${ }^{17}$ Zeami's three plays examined in this thesis belong to the demon roles danced in the style of saido fü. Not only was he aware of the category of Ukai according to this play's leading character, but he also was careful in prescribing in which style among the two demonic performance styles should be used. As we can see in this example, even though the program format had not been officially established, Zeami, and Nobumitsu two generations later, recognized and referred to categories in noh treatises. Having these noh categories in mind, Zeami and Nobumitsu wrote plays with demons in them that have survived until present day. These demon noh plays include the human-like main characters, such as the mountain hag in Yamanba. However, their plays

\footnotetext{
${ }^{15}$ For example, in his treatise "Kashū no Uchi Nukigaki," Zeami mentioned five plays in a day program in the order exactly matching the official format mandated by the Edo Bakufu. However, the time in which Zeami lived was the early Muromachi period approximately 160 years before the foundation of the Tokugawa Shogunate (1603), and the official program format was established in the Edo period. Whether the government officials and noh troupe leaders of this later time referred to Zeami's treatises is not clear. However, the important thing here is that the demon noh plays in the present day have the same kind of leading character demons as in plays in Zeami's and Nobumitsu's time.

16 “Kashū no Uchi Nukigaki,” Zeami Zenchiku, pp. 68-69; Hare, pp. 77-78.

17 “Nikyokusantai Ningyōzu,” Zeami Zenchiku, pp. 127-129; Hare, pp. 144-146.
} 
also include entirely non-human monsters such as nue and Yamata no Orochi.

\section{Demons in Noh Plays by Zeami and Nobumitsu}

The three Zeami plays I investigate are Yamanba, Nue, and Ukai. ${ }^{18}$ The demon characters in these three plays are very different. The play Yamanba presents a mountain hag (yamanba 山姥), a female half-human demon (kijo 鬼女) living in the mountains without connection to human society. This mountain hag, yamanba, is a unique example because she is half-way between demon and human. Yamanba literally means the old woman in the mountains. Because a mountain hag sometimes kills travelers and devours them, ${ }^{19}$ this creature was considered to be a demon by contemporary Japanese people. The titular creature in Zeami’s play Nue (鵺, Monster Nue) has features of monkey, tiger, serpent, and Japanese raccoon dog (tanuki). The nue monster's voice sounds like scaly thrush's singing (toratsugumi), which was also called nue. A nue monster has flying capability through its supernatural powers even though it does not have wings. The nue in the play appears first in The Tale of Heike (Heike Monogatari 平家物語), and it repeatedly attacked the imperial palace terrifying people living there. ${ }^{20}$ The play Ukai (鵜 飼, The Cormorant Fisherman) has a unique demon. He is Enma Daiō, the great King of Hell. In the play, he witnesses the salvation of a dead fisherman's soul. As we can see in

\footnotetext{
${ }^{18}$ Sanari, pp. 297, 2377, and 3165. Ukai was originally written by Enami no Saemon Gorō (dates unknown), but significantly rewritten by Zeami.

${ }^{19}$ Japanese studies scholar Noriko Reider states yamanba in the early classical literature was often an old lady who turned into a harmful female demon, sometimes devouring human beings who happen to cross her path, as seen in Konjaku Monogatari Shü. For more details, see Reider, p. 239.

${ }^{20}$ For an image of the nue monster, see Figure 3 in Appendix A.
} 
these descriptions, Zeami applied a much broader concept of the demon than modern demons when writing his demon noh.

The later playwright, Nobumitsu, also wrote many demon noh plays including the three plays I will analyze: Momijigari, Rashomon, Orochi. As I mentioned earlier, the play Orochi (大蛇, The Great Snake) features a gigantic serpent with eight heads and eight tails, a monster from Japan's oldest mythology. Nobumitsu chose different kinds of demons from Orochi for the plays Momijigari and Rashomon. The demon in the play Momijigari (紅葉狩, Maple Viewing) is a violent ogre. Although she appears as a noble lady in disguise in the first act, her true identity is an ogre from the beginning of this play.

The demon in Rashōmon (羅生門, Rashōmon Gate) was an aristocratic woman in the source story. According to a source story in The Tale of Heike, she turned into a demon because of her lover's betrayal. ${ }^{21}$ The play script of Rashömon does not include any information about how or why she turned into a demon. The only information presented about her in the play is that warrior characters call her a demonic god (kijin 鬼 神) who lives in the great gate of Rashōmon. These two demons in both plays Momijigari and Rashōmon are so full of hatred that they seek to harm all humans. As we can see in these descriptions of a giant serpent and these demons, Nobumitsu also had a broader idea about demons than the modern concept when writing his demon noh.

Among these demonic creatures in the plays written by Zeami and Nobumitsu, the creatures in Nue and Orochi are not typically considered to be demons by modern Japanese people - they would refer to these creatures as mythical monsters (bakemono 化

21 “Tsurugi no Maki,” Heike Monogatari, pp. 2-5. 
け物 or kaibutsu 怪物). This variety shows, for Zeami and Nobumitsu, demons included a much broader array of supernatural beings, ranging from mythical monsters to humanlike creatures. In order to understand the major characteristics of demons in premodern Japan, I would like to examine what kind of monsters were considered to be demons prior to the Edo period.

\section{Major Characteristics of Demons in Japan}

Komatsu claims that there were a wide variety of demons in the Muromachi period. According to him, the origin of the word oni 鬼 came from on 隠, which means hiding, unknown, or invisible. ${ }^{22}$ Oni (demons) are hiding and invisible, and they provoke fear because they are unknown, and people do not know what to do in order to cope with them. This broad definition of demons could include a variety of mythical monsters. Komatsu states that in the Muromachi period, demons included many creatures with very different features. In the 15th-century Buddhist painting scroll Nakifudōengi Emaki, a variety of demons are painted on the scroll. Some demons have horse heads with humanlike bodies. Others have ox heads with human-like bodies. Another is a huge face washing bowl monster with face and on legs, a grotesque transformation of an implement used by courtly women in the Heian period. ${ }^{23}$ These demons diverge from the modern version of demons. Komatsu explains bakemono (化け物, transformed monsters) and yōkai (妖怪, monstrous beings) replaced the word oni to refer to many non-human

\footnotetext{
${ }^{22}$ Komatsu, Oni to Nihonjin, p. 47.

${ }^{23}$ For an illustration of this face washing bowl monster, see Figure 4 in Appendix A. Also, see Komatsu, Oni to Nihonjin, pp. 25-28.
} 
creatures like these. ${ }^{24}$

These very different looking demons share many standard features. ${ }^{25}$ Some of them are fallen humans. In Japanese literary tradition, we see many examples of humans becoming demons when they have intense resentment against something or someone. In noh plays, these demons include Lady Rokujō's spirit in Aoi no Ue, a lady in the capital in Kanawa, and a shirabyōshi dancer in Dōjōji. All of them are women betrayed by their lovers, and these women turned into demons because of their intense resentment. ${ }^{26}$ Among the plays addressed in this thesis, the demon in Rashomon is of this type. In "Tsurugi no Maki" of The Tale of Heike, an aristocratic woman becomes demonic after praying at the Kifune shrine to become a demon because she is so jealous of a romantic rival. ${ }^{27}$ She kills the romantic rival and all the family members of that rival and her lover's family members. People in Kyoto were so afraid that they did not go out during the night. This happened before this female demon started appearing at the bridge of Ichijō Horikawa in Kyoto. Nobumitsu turned this legend into his noh play, and he changes the location from the bridge to the Rashōmon gate. But, he left out the demon's origin story.

\footnotetext{
${ }^{24}$ Komatsu, Oni to Nihonjin, pp. 34-35.

${ }^{25}$ Komatsu, Hyōrei Shinkō Ron, pp. 216-218.

${ }^{26}$ These plays are often categorized as the fourth category, miscellaneous plays, which include deranged or distraught human characters in the leading roles. Their identities as human differentiate them from demons in the fifth category. However, some scholars place humans who transform into demons in the fourth category. These scholars allow a fourth category, sub-category, of female demon plays (kijomono 鬼女物). Categorization of noh plays is sometimes inconsistent over time and among different noh schools and scholars.

27 "Tsurugi no Maki," Heike Monogatari, pp. 2-5. Heike Monogatari has different streams of transcripted manuscripts. “Tsurugi no Maki" is in “hyaku nijikku bon 百二十句本” of Heike Monogatari. Also, noh scholar Ikai Takamitsu states that Taiheiki volume 32 was another pre-existing source which has a similar plot. Ikai, pp. 270-273.
} 
Another recurring feature among demons is that some Japanese demons' behavior and attitude toward humans seem to reflect the Chinese cosmology of hell. ${ }^{28}$ In Chinese cosmology, some demons are the protectors of hell, who judge and punish the sinners in their afterlife. The most famous example is Enma Daiō, the great king of the underworld. He judges the behavior of each person upon their death and sends them to different levels of hell accordingly. He has retainers who help him to carry out this task and who punish sinners by inflicting pain on them. These retainers usually look similar to the modern concept of oni. We see Enma Daiō in Zeami's play Ukai. He does not harm people in this play, but rather appears to the monk and tells him that the soul of the cormorant fisherman is now saved thanks to the power of the Lotus Sutra. In fact, there are many stories and plays in which Enma Daiō allows dead souls to either return to earth or go to heaven. ${ }^{29}$

In Japanese literary tradition, the authors of stories and plays about demons fictionalized political enemies into demons because they did not follow the order of central government. Folklore studies scholar Wakao Itsuo compares the regional record with the noh play Shūyōshō Tamura (no longer performed) to show how people associated demons with opposing political parties. ${ }^{30}$ The regional record lists four powerful and demonic retainers of Fujiwara no Chikata. Their names Kinki 金鬼, Fūki 風鬼, Suiki 水鬼, and Ongyōki 隠形鬼, clearly indicate they are demons by character $k i$

\footnotetext{
${ }^{28}$ Komatsu, Hyōrei Shinkō Ron, p. 216.

${ }^{29}$ Other examples include the story of Fujiwara no Yoshimi, the minister of Nishisanjō, brought back to life in Konjaku Monogatari Shī, and the kyoggen play about Asahina Yoshihide, a powerful samurai, tricking Enma Daiō to take him to heaven in Asahina.

${ }^{30}$ Wakao, p. 216.
} 
鬼. In comparison, the noh play lists the four retainers as powerful mountain wizards with human names: Yama no Chūki, Mikawa-bō, Hyōgo no Rissha, and Tsukushi-bō. Although they are humans, the legend in the play states that they were so powerful they could knock down trees and crush large rocks into pieces. Mountain wizards (yamabushi 山伏) were considered frightening and almost superhuman thanks to their magical power and wild appearance. ${ }^{31}$ This is similar to quasi-humans such as yamanba. Thus, these four are composites of human and the demonic in Japanese literary traditions. Wakao argues that Fujiwara no Chikata was the head of a powerful family with many iron furnaces ${ }^{32}$ and he was killed because he rebelled against the central government. Later, his story was fictionalized and he was depicted as the head of demonic retainers. ${ }^{33}$ Regional history scholar Takioto Yoshiyuki writes that this sort of fictionalization occurred in the mythology of Yamata no Orochi, the source story of Nobumitsu's play Orochi. Takioto claims that Yamata no Orochi symbolizes a hostile shore-dwelling tribe in the coastal area of Izumo, who were conquered by Yamato Japanese symbolized by Susanoo no Mikoto. $^{34}$

The ubiquitousness of demons in Japanese literature and the multiplicity of origin stories, appearances, and motives for actions make it clear how important they are in

\footnotetext{
${ }^{31}$ Wakao, p. 158.

${ }^{32}$ This legend occurred in the Iga region, where anti-government forces existed for many centuries, and they were the center for Shugendo sect, the religion of mountain wizards. Later, some of the wizards founded secular ninja families. After doing the fieldwork in the region, Wakao found out that this region's soil is rich in iron and theorized that there were many iron mines and furnaces in the 6th century. For details, see Wakao, pp. 216, 218.

${ }^{33}$ Wakao, p. 218.

${ }^{34}$ Takioto, p. 4.
} 
early Japanese culture. Now, let us investigate demons in noh plays.

\section{The Importance of Demon Noh}

Just as demons played an important role in Japanese culture as a whole, so they were important in noh plays. One early purpose of noh performance was to pacify the souls of evil spirits or ghosts in religious rituals such as Shushōe 修正会 and Shunie 修 二会 in the Buddhist temples in Nara. ${ }^{35}$ In "Sarugaku Dangi," among all the dances and songs, Zeami considered Okina to be the most exalted form of auspicious performance because noh actors performed it to chase away evil spirits, and to bring happiness and peace among people and in the land of the emperor. ${ }^{36}$ These religious rituals were also intended to pacify evil spirits (chinma 鎮魔) ${ }^{37}$ and cleanse impurity (kegare 穢れ) in the nation, according to noh scholars Omote Akira and Amano Fumio. ${ }^{38}$

In early Japan, these religious rituals had significance not only for religious institutions but also assisted an essential function of the central government to protect peace in the land. ${ }^{39}$ The political requirement to protect the land led to the beginning of these rituals at government-related temples. In order to protect the capital from malicious spirits, the emperor ordered temples such as Tōdai-ji temple and Kōfuku-ji temple to

\footnotetext{
35 Omote and Amano, Nōgaku no Rekishi, p. 21.

36 "Fūshikaden" and "Sarugaku Dangi," Zeami Zenchiku, pp. 38-41, 260; Hare, pp. 47-52.

${ }^{37}$ Raiden (雷電 or 来殿) is one of the representative noh plays about pacifying the angry soul of a vengeful spirit. In the play, the wrath of Sugawara no Michizane's ghost is pacified when the Emperor gives Michizane the accolade of a heavenly deity (Tenjin).

${ }^{38}$ Omote and Amano, Nōgaku no Rekishi, p. 21.

${ }^{39}$ Suzuki, Masataka, p. 74.
} 
conduct Shushōe every year. Jushi (呪師, Shugendō exorcist) of Shugendō sects (修験 道, mountain ascetic shamanism) conducted a ritual performance jushi-hashiri (呪師走 り, exorcist run) to invite benevolent deities to the capital and to create a spiritual shield for chasing away evil spirits from the capital. ${ }^{40}$ Shugendō was a Japanese syncretic religion combining Shintō elements with Tantric Buddhism (mikkyō 密教). Later, jushihashiri was used as a part of the celebratory performance Okina ${ }^{41}$ As noh performance was presented with Okina in these government-related religious rituals, the origin of noh shows the nation and ruling elites had highly political purposes for presenting noh plays as Zeami explains in "Fūshikaden."

Another reason for demon noh's significance is that it has a special position in noh's performance program. Noh has five categories of plays. Demon noh constitute the fifth and last category, and demon plays are presented as the climax to conclude a day's program. These plays are faster in tempo and with more percussion, making them very energetic. Demon noh plays conclude the day's performance with a strong impression. In his treatise "Nikyokusantai Ningyōzu," Zeami wrote that it is important to use these striking pieces carefully and strategically when organizing day-long or multiple-day performances. ${ }^{42}$ His purpose was to keep the long program interesting for spectators and patrons.

In order to keep the programs intriguing for audiences, a wide variety of

\footnotetext{
${ }^{40}$ Suzuki, Masataka, pp. 75-76.

${ }^{41}$ Suzuki, Masataka, p. 78.

42 “Nikyokusantai Ningyōzu," Zeami Zenchiku, p. 129; Hare, p. 146.
} 
characters and acting styles are important in noh as Zeami explains in his treatise "Fūshikaden." ${ }^{43}$ Demons in noh are very different from one type to another. Generally speaking, there are four types of demons in noh. The first kind of demon are non-human monsters who are enemies of humans. They inflict harm or death on humans. The second kind is halfway between demon and human, such as the mountain hag in the play Yamanba and the demon in the play Rashomon. These two are demons who transformed from female humans. They differ in the degree to which they hate and want to harm humans. The third kind of demon in noh play is a human ghost that seeks to harm those who wronged them. This type includes Taira no Tomomori in Funa Benkei and Lady Rokujō's spirit in Aoi no Ue. The fourth kind is Enma Daiō and his servant demons, who deal with dead human souls usually by punishing and torturing them, and occasionally by sparing them.

Noh's Founder Zeami, and Demon Noh as the Conclusion of the Noh Program

Scholars consider Zeami to be the founder of noh, integrating all the conventions theorized and practiced by his father Kan'ami (1333-1384) in his noh plays. Even though Zeami created this art form by abiding by many conventions of noh's precedent performative genres, he transformed noh into the sophisticated art which survives until today. His innovation relied on two important elements, dance and singing along with poetry. ${ }^{44}$ He was the first theorist to write about playwriting, training, and performing in

\footnotetext{
43 “Fūshikaden," Zeami Zenchiku, p. 56; Hare, p. 65.

${ }^{44}$ For the introduction of Zeami's artistic interests, see Yokomichi, Hata and Nishino, No no Sakusha to Sakuhin, pp. 177-184.
} 
addition to mastering their practice.

Zeami paid great respect to the performance of demon noh. Some portions of his treatises refer specifically to demon noh. As Zeami wrote in "Fūshikaden," Yamato sarugaku schools were known for skillfully performed demon noh plays. Equipped with this tradition of fine performance of demon noh, Kan'ami founded the Yūzaki troupe (Yūzaki-za 結崎座), which later became the Kanze school. In "Sarugaku Dangi,” Zeami wrote that this category is the kind of play, which only well-experienced actors should perform..$^{45}$

In order to assist performers in making a strong impression while playing demons, Zeami theorized a way to increase impressiveness as the performance moves toward its climax. He applied the musical structure of introduction, development, climax (jo ha ky $\bar{u}$ 序破急) to the structure of every aspect of his dramaturgy, as one can see in “Kashū no Uchi Nukigaki. ${ }^{46}$ In the organization of a day-long program of plays, jo means the beginning and foundation, when noh plays should be classical, straightforward, celebratory, and orthodox. The tempo should be slow, and the characters should be clearly introduced. $\mathrm{Jo}$ of the program is a god play. $\mathrm{Ha}$ is the longest and most sophisticated portion of a program. The main themes and characters are elucidated, and their feelings and experiences should be easy to understand. The $h a$ of day's program consists of a warrior play, a woman play, and a miscellaneous play. $K y \bar{u}$ is the finale and concludes the performance, so plays should be fast in tempo and have powerful

\footnotetext{
45 “Sarugaku Dangi,” Zeami Zenchiku, p. 261.

46 “Kashū no Uchi Nukigaki,” Zeami Zenchiku, pp. 68-69; Hare, pp. 77-78.
} 
movements. $K y \bar{u}$ should conclude the whole program, surprising and intriguing spectators. Demon plays were presented as the kyu portion of a full day's program. Zeami wrote that a demon play should be performed only once in the whole program as the finale.

However, each individual play itself had a jo ha kyū structure. Zeami believed that the $h a$ portion of his demon plays was important and he wanted the audience to understand the demon character. Therefore, he made sure not to distract the audience by placing secondary demons along with the main character. When Zeami wrote plays with powerful movements, only one character at a time danced.

In order to understand the different characterization and dramaturgy between Zeami and Nobumitsu, I will analyze three demon noh plays by each of the two authors. Zeami's plays are Yamanba, Nue, and Ukai. Nobumitsu's plays are Momijigari, Rashömon, and Orochi. I selected these plays because of the certainty of authorship and the play scripts' accessibility. I will introduce an overview of distinctive characteristics of plays by each playwright, Then, I will briefly provide the plot summary, casting, and major dance sections of each play. This information is essential because I will focus on analyzing these aspects of plays in later chapters.

Overview of Zeami's Demon Noh and its Major Characteristics

One of the most insightful characterizations of noh is by Japanese literature scholar Kenneth Yasuda. Yasuda defines noh as a drama of the exploration of the soul. ${ }^{47}$

${ }^{47}$ Yasuda, Masterworks of the Nō Theater, p. 1. 
This focus on the human soul is largely attributed to Zeami. Noh scholar Yokomichi Mario refers to Zeami's plays as drama noh (geki noh 劇能) by defining geki as the art which utilizes the character's own voice and behavior to portray his thoughts and feelings. ${ }^{48}$ According to this description, even demons are humans for Zeami. Zeami himself characterized demons as having human qualities (saidō-f $\bar{u})$ as we see in his treatises.

Zeami wrote only a few demon noh plays. Zeami wrote many more noh plays in other categories than demon noh. However, his demon noh include some of the most frequently performed plays throughout the history of noh. Historical records compiled by noh scholar Nose Asaji show the number of performances for each play in the Muromachi period. ${ }^{49}$ This data indicates that Zeami's demon noh plays were performed often in the Muromachi period. These frequently-performed plays include three works I will analyze.

\section{Yamanba: Plot Summary}

Yamanba is about a female courtesan and her attendants on a pilgrimage who encounter a mountain hag, who is considered to be a demon by the Japanese people. The courtesan has become well-known in the capital for her dance in which she enacts a mountain hag. The real mountain hag, appearing as a village woman, wants the courtesan

\footnotetext{
${ }^{48}$ Yokomichi, Nōgeki no Kenkyū, p. 43.

${ }^{49}$ Nose, Nōgaku Genryūkō, pp. 1260-1320. As Nose explains in p. 1260, the performance record in the Muromachi period is limited in number. The sample number is small, but Nose asserts that it shows the general tendency of popularity and importance. The three plays Yamanba, Nue, and Ukai were performed 59 times, 33 times, and 23 times, respectively. Among the 292 plays on the list, the average number of performance is 9.6 times. Therefore, these three plays were presented frequently.
} 
and others to recognize how a real mountain hag differs from the story in the popular dance. She wants them to understand how she suffers living in wild mountains. In the second act, the mountain hag reveals her true identity and tells her story of life in the mountains. This mountain hag is the embodiment of nature, both nourishing and dangerous. When the mountain hag tells her story to sympathetic listeners, her anger and resentment diminish, and she disappears into the wilderness.

\section{Yamanba: Casting and Major Dance Section}

In noh, the leading actor who plays the protagonist is called shite actor, which means "doer" actor. The primary supporting role is called waki actor, which means supporting actor. In Yamanba, the shite actor plays the role of a village woman in the first act, and the mountain hag in her true form in the second act. When she appears in her true form, the actor wears a demonic mountain hag mask with golden eyes (yamanba 山姥). The waki plays a male traveler. Another supporting actor, the tsure actor, plays the famous courtesan wearing a mask of young woman (koomote 小面) whom the male traveler is accompanying.

Zeami concludes the play with the climactic dance by the mountain hag in the last act. After the mountain hag urges the courtesan to perform her dance, the mountain hag starts to dance while the chorus sings her lines describing her life in the mountains, a life filled with anguish and beautiful nature. She also tells of her intention to reach to nirvana by overcoming the perception of duality. Even though the mountain hag is a supernatural monster, Zeami gives her scenes of singing and dance to explore her interiority-her feelings and her soul. 


\section{Nue: Plot Summary}

Nue is a mythical monster with the face of a monkey, the legs of a tiger, the body of a Japanese raccoon dog (tanuki) and the front half of a snake for a tail. In Nue, the spirit of a nue monster tells a traveling monk how Minamoto no Yorimasa 源頼政 (11041180) shot him down and killed him. This nue monster was a dangerous creature who attacked Emperor Konoe's palace in the capital of Kyoto during the night. When the sky darkened with gloomy clouds, the nue appeared flying in the air. Summoned as a bodyguard by the emperor, Yorimasa prayed to the Hachiman deity and shot an arrow with a mighty bow, felling the nue. Because of the blessing of Hachiman deity, the arrow flew straight and true, hitting the nue. Losing its supernatural power because of god's punishment, the nue fell to the ground. Then, Yorimasa's powerful retainer, I no Hayata 猪早太, stabbed the nue nine times with a sword, killing him. In the first act of Nue, the spirit of the nue monster appears disguised as a boatman, walking on the seashore in Settsu Province (near the town of Ashiya). This is because after the nue was killed, its corpse was thrown in an empty boat in the Yodo River, which flowes into Osaka Bay. ${ }^{50}$ After telling the story of his death and his suffering in hell because of his sin, the nue spirit asks the monk to pray for its soul to rest in peace. In this way, the power of Buddhism pacifies the suffering soul of the monster.

\section{Nue: Casting and Major Dance Section}

\footnotetext{
${ }^{50}$ In The Tale of Heike, the dead nue gets thrown into a boat in the Kamo River. In the play, Zeami writes it is Yodo River. Sanari, pp. 2391-2392.
} 
In Nue, the shite actor plays the role of a boatman in the first half with a male

ghost mask (mikazuki 三日月) and nue monster ghost with a monster mask (kotobide 小

飛出) in the latter half. This mask represents agile deity or demon with supernatural

power. The waki plays a traveling monk.

Zeami concludes the play with the climactic dance by the nue monster in the last act. The nue tells how he attacked the Emperor's palace and got killed by Yorimasa and his retainer. The shite actor recreates the battle scene by dance movements. After confessing everything, the nue monster disappears into darkness along with the reflection of the moon on the ocean. In Nue, Zeami treats his subject very differently from its original story in The Tale of Heike and explores the soul of the nue monster.

\section{Ukai: Plot Summary}

In Ukai, a traveling monk from Awa Province meets an old cormorant fisherman. The fisherman starts telling the story of a cormorant fisherman from old times. Because he was fishing in a prohibited area, he was killed by furious villagers. The storyteller confesses his true identity—he is the dead cormorant fisherman's ghost suffering in hell, and the ghost asks the monk to pray for his salvation, and then disappears. In the second act, we learn that local monks sank stones wrapped with copies of the Lotus Sutra (Hokekyō 法華経) into the river to succor the wandering spirit of the cormorant fisherman. Enma Daiō, the great demon king from hell, appears, declares that the cormorant fisherman's soul is in peace, and praises the power of the Lotus Sutra. In Ukai, the demon Enma Daiō is a righteous observer, and he tells how the soul of the cormorant fisherman was pacified. This King of Hell does not possess violent intent against humans. 
This portrayal of Enma Daiō follows Chinese cosmology, adapted from the Tiantai (Tendai) Buddhism.

\section{Ukai: Casting and Major Dance Section}

In this play, the shite actor plays two roles with different identities, unlike the other two plays by Zeami. In the first act, the shite actor plays an old cormorant fisherman wearing an old man mask (asakurajō 朝倉尉). The actor switches his role into Enma Daiō in the second act wearing a mask of a demon from hell (kobeshimi 小癋見).

The waki actor plays the role of a traveling monk and wears no mask throughout the play. He is accompanied by a secondary monk.

In the first half, the cormorant fisherman dances to demonstrate his fishing using a torch in the pitch-dark night. As the moon comes out of the clouds and starts shining brighter, he disappears into the darkness. In the second half, after engaging in a dialogue about Buddhist teachings with two monks, the King of Hell Enma Daiō concludes the play with a climactic dance with the chorus singing Enma Daiō's words praising the power of the Lotus Sutra. Zeami wrote this play differently from other two plays in that the play does not explore the soul of a demon, but instead the soul of a sinner who is saved by the power of the Lotus Sutra. The demon witnesses to and recounts this salvation. Although the climax diverges from the typical structure of Zeami's demon noh plays, the focus remains on the drama of the interior suffering and struggle of human souls. 
Another playwright I investigate in this study is Kanze Nobumitsu, one of the most prominent noh playwrights in the late Muromachi period, two generations after Zeami. He was the troupe manager of the Kanze School, founded by Zeami. ${ }^{51}$ Nobumitsu was called Kanze Gon no Kami, meaning the Kanze troupe's manager even though the historical record shows he was not a shite actor. According to his biography written by Rinzai Buddhist monk Keijo Shūrin, he was an accomplished drum player and noh playwright.

In contrast to Zeami's demon pacifying noh, Nobumitsu wrote many noh plays with stage acting depicting violent conflicts. The conflicts conclude with heroes killing demons. Nobumitsu wrote many furyū noh 風流能 (spectacle noh). The first appearance of this term is by noh scholar Yokomichi Mario. In his book Nōgeki no Kenkyū, Yokomichi suggests using the term furyū noh to classify noh plays such as Kagetsu, Hagoromo, and Tsuchigumo because these noh plays present the stage spectacle or stage entertainment with energetic dances by actors in elegant costumes. ${ }^{52}$ He adapted the concept of fury $\bar{u}$ from other popular, participatory activities in the medieval period such as prayer chanting (nenbutsu 念仏) fury $\bar{u}$ and festival dancing. Participants from all classes dressed up in colorful costumes, sung and danced. Spectacular fury $\bar{u}$ noh plays are very different from Zeami’s plays.

One of furyū noh's differences from Zeami's geki noh is that furyū noh characters

\footnotetext{
${ }^{51}$ Nobumitsu was the seventh child of On'ami, also known as Kanze Motoshige (1398-1467). On'ami was Zeami's nephew. Nobumitsu was born one year after Zeami was sent into exile to Sado Island. See Yokomichi et al, Nō no Sakusha to Sakuhin, p. 256.

52 Yokomichi, Nōgeki no Kenkyū, p. 46.
} 
are often corporeal beings living in the present of the noh play. They are not ghosts in the present, who were corporeal beings in the past. In addition to presenting lively dances in beautiful costumes, a major characteristic of Nobumitsu stage spectacle is large cast plays with many characters engaging in energetic danced combat. Nobumitsu's plays end with the victory of good over evil.

In the two generations after Zeami's death, the political situation had changed considerably in Japan, meaning significant change in the patronage of noh plays. Kyoto was destroyed by the Ōnin War (1467-1477), and the Ashikaga Shogunate had grown weak and had almost no remaining sources of revenue. In Nobumitsu's day, regional rulers and religious institutions were his patrons. These patrons enjoyed spectacle on stage, and this is what Nobumitsu gave them. Nobumitsu wrote demon noh plays in fury $\bar{u}$ noh style and also plays with exotic themes such as Chinese plays (kara mono 唐物), samurai war plays, and plays based on Japanese mythology. For analysis, I have chosen three demon plays certain to have been written by Nobumitsu.

\section{Momijigari: Plot Summary}

In Momijigari, Taira no Koremochi 平維茂 goes deer hunting in the mountains and finds a noble aristocratic lady alone only with her servant ladies having a banquet and viewing autumn leaves. Koremochi drinks sake with the noblewoman while appreciating the beautiful autumn leaves, and falls asleep. Ai-kyogen is the interlude between two acts of one noh play. During the ai-kyoggen section, a servant deity of the god Hachiman appears in Koremochi's dream and tells him the beautiful ladies are demons in disguise and gives him the blessing of Hachiman god and a divine sword from 
the deity. Koremochi wakes up, and the Hachiman god's sword is still there beside him. Soon the ladies reveal themselves as demons and attempt to kill Koremochi. Koremochi fights back and kills the demons with Hachiman's sword. In this play, these demons are portrayed as evil and powerful, but they are destroyed by Koremochi, a warrior hero with the righteous blessing of a god.

\section{Momijigari: Casting and Major Dance Section}

In Momijigari, the shite actor plays the role of a noblewoman with a mysterious young woman mask (zōonna 増女) in the first act and a demon with a ferocious demon mask (shikami 韽) in the second act. ${ }^{53}$ Depending on directions, there are three to five tsure actors who play her accompanying demons wearing similar masks. Although Koremochi is an important character in the play and achieves a heroic victory, he is played by the waki actor and wears no mask. The presence of heroic supporting characters on stage is one of the distinctive features of Nobumitsu's plays. The kyōgen actor is significant in the development of the plot in this play, playing the role of a servant deity who aids Koremochi in the ai-kyōgen section. He wears a kyōgen god mask. After the ai-kyōgen by the servant deity, Koremochi wakes up, and the female demons appear on the stage, accompanied by intense music. The play concludes with a fast-paced danced battle between Koremochi and the demons. After the demons start attacking

\footnotetext{
${ }^{53}$ The Kanze school has two different stagings ( $k a e$ 替工, alternative direction) for Momijigari. Alternative staging specifies a hannya mask (般若, female demon mask) and Koremochi fight only with a single demon, not a head demon and its subordinates. Most of the time, noh actors choose the demon group (oni zoroe 鬼揃) staging, in which the primary demon is female and accompanied by other female demons. In this alternative staging, Koremochi fights with all the female demons.
} 
Koremochi, none of the actors sing or speak. Instead, the chorus provides the sung narration describing each attack as it happens on the stage.

Nobumitsu wrote lines for the female demon to speak while she disguises herself as a noble lady and seduces Koremochi by getting him drunk. This part of the play features elegant conversation describing beautiful nature and their predestined meeting. However, there are no lines expressing any concern for the demon's soul nor is there any confession by the demon. Although the sung script is impressive in the first act, Nobumitsu's primary purpose in this play seems to be the battle scene danced in fast tempo and the decorative presentation of many actors, ladies and demons, all wearing beautiful costumes.

\section{Rashōmon: Plot Summary}

Rashōmon is about an heroic exploit by Watanabe no Tsuna 渡辺綱 (953-1024), one of the four valiant retainer warriors of Minamoto no Raikō 源頼光 (944-1021). The four retainers, including Tsuna, were known as shitennō 四天王 (four heavenly kings). When Raikō and his retainers, including Tsuna, are enjoying a banquet, another courtier, Fujiwara no Yasumasa, mentions a mysterious rumor. The rumor is that people are now avoiding the Rashōmon (the great gate at the southern entrance to Kyoto) after dark because a dangerous demon dwells there. Tsuna rebukes Yasumasa for telling this kind of inappropriate story because the gate is meant to protect the capital of Kyoto, where the emperor lives. After arguing with Yasumasa, Tsuna goes to Rashōmon gate on his own deep in the night. Because he does not notice anything strange there, he sets out for home after placing evidence of his inspection on a signboard given him by Lord Raikō. 
However, suddenly the hand of the demon appears in the darkness and grabs the edge of Tsuna's war helmet. Cutting the cord of his helmet so that it is pulled off, Tsuna turns around and fights back against the demon. She is a female demon as tall as the roof of Rashōmon gate. After a fierce battle between them, Tsuna finally defeats the demon by cutting off one of its arms. The demon cries out that she will return to take her arm back and disappears into a black cloud.

\section{Rashōmon: Casting and Major Dance Section}

Unlike conventional noh plays, the shite actor, who plays the demon, appears only in the second act. This is very unusual even for Nobumitsu's plays. All the warriors including Raikō and Tsuna are played by other actors without masks. Tsuna, played by the waki actor through the entire play, is more important than the demon in the plot. Another distinctive feature of this play is the shite actor's mask, which is a grimacing male demon mask (shikami 頍). This mask is typically used for male demons, and Nobumitsu chose to use the word “fierce demon god" (kijin 鬼神) to refer to the demon living in Rashōmon gate. The source story is a famous story about an aristocratic lady turning into a female demon (kijo 鬼女) in “Tsurugi no Maki” of The Tale of Heike. Having a powerful and enormous male demon represent or replace a female demon makes the battle more ferocious. This kind of strong demon is a better match for the legendary warrior Tsuna.

\section{Orochi: Plot Summary}


Orochi is a noh adaptation of a Japanese myth in Kojiki and Nihon Shoki about Susanoo no Mikoto 素戔嗚尊, a powerful deity who slays Yamata no Orochi (an eightheaded and eight-tailed giant serpent). When Susanoo no Mikoto descends from the divine realm to Izumo Province, he sees an elderly father god Tenazuchi and elderly mother god Ashinazuchi crying because they have to give their daughter Kushinada to Yamata no Orochi, who eats the maidens given him as sacrifices. Susanoo asks the parents to let him marry their daughter if he rescues her, and they agree. Then, Susanoo sets out to destroy Yamata no Orochi. He orders to construct eight 15-meter scaffolds and places on them eight large tubs full of sake. After floating these sake-tubs on the water of Hinokawa river, he magically causes the image of Kushinada to appear on the surface of the sake. In this way, Susanoo tricks the giant snake into swallowing the reflection of Kushinada and drinking the alcohol, making the serpent drunk. Because of the alcohol, the serpent loses its supernatural ability to fly, and Susanoo attacks the monster with his divine sword. Although the serpent fights fiercely, Susanoo no Mikoto manages to kill the monster and obtains the legendary sword named Murakumo from the serpent's tail.

\section{Orochi: Casting and Major Dance Section}

In Orochi, the shite actor plays the role of an old deity Tenazuchi with an elegant old man mask (kojo 小尉) in the first act. In the second act, a shite plays Yamata no Orochi with a black beard mask (kurohige 黒髭) which represents a dragon god (ryüjin 竜神). These two characters are not related to each other in any way. One of the distinctive features of this play is that the waki actor plays the role of a god without 
wearing a mask. This kind of role assignment and direction does not happen in Zeami's plays or any other plays in the noh repertory. Characters without masks are humans in Zeami’s plays.

After Susanoo no Mikoto vows to bring peace to the land by destroying Yamata no Orochi at the beginning of the second act, none of the characters speak lines. All vocals are by the chorus from this point onward. This depiction without speaking lines shows that Yamata no Orochi is an evil monster which the virtuous need to destroy. The monster has no vocal part. The chorus sings the entire second act, describing what happens in the battle, and the great serpent played by the shite actor and Susanoo no Mikoto fight fiercely. Nobumitsu's intention for this play was to focus on the stage spectacle of the battle.

As I examined in this chapter, the role assignment of characters to waki actors and the number of performers on the stage is very different between Zeami's demon noh plays and Nobumitsu's. I will discuss these features in detail in subsequent chapters.

Research Methodology and Procedure

As for research methodology and procedure, the primary sources will be play scripts. I will analyze the original texts, written in Japanese, mainly in Yōkyoku Taikan noh anthology because this anthology includes scripts of ai-kyōgen. Although the scripts of ai-kyōgen have changed frequently over the centuries, ai-kyōgen texts need to be considered because of their importance in the plots of Nobumitsu's plays. For supporting my analysis, I will refer to treatises by Zeami and a variety of recent and contemporary scholarly research conducted on Zeami and Nobumitsu and their works. 
Chapter 2: Zeami and Nobumitsu: Changing Social Values and Aesthetics in the Muromachi Samurai Elites

When stories are frequently retold, slight changes that are made over the centuries reflect changes in the social and cultural core values of new listeners and audiences. In noh plays, these core values reflected in selection of stories, as well as characterization and dramaturgy. How differently Zeami and Nobumitsu depicted demons in their plays shows the different values, beliefs, and preferences among their audiences. In this thesis, I refer to this social and cultural core value as an ethos. According to Oxford English Dictionary, ethos is "the characteristic spirit of a people, community, culture, or era as manifested in its attitudes and aspirations; the prevailing character of an institution or system." "54 The different approaches to characterizing demons in their plays demonstrate that a different ethos existed among their patrons when Zeami and Nobumitsu wrote the plays. In order to understand these differences in their attitudes and aspirations, in this chapter, I will examine the social and cultural situation when these two playwrights were active.

As Zeami explains in "Sandō," also called "Nōsakusho," noh plays' source stories have to have two characteristics: they must be easily adaptable to portray characters using song and dance, and they must be well-known to the audience. He gives the example of Ariwara no Narihira and Genji for male roles, as well as Ono no Komachi and Shizuka Gozen for women roles. ${ }^{55}$ These men and women were famous for their poetry and dance performances. Also, the source stories have to be familiar to the audience. Zeami's

\footnotetext{
54 "ethos, n." OED Online.

55 "Sandō," Zeami Zenchiku, p. 134.
} 
patrons were familiar with the popular dance of the mountain hag ("Yamauba no Kusemai 山姥の曲舞”) and they knew the nue monster's story in The Tale of Heike. The source story of Ukai is unknown. However, the custom of cormorant fishing (ukai) itself and the Buddhist teachings of forbidding killing animals were already well known among Zeami's patrons. Although Nobumitsu never wrote his treatises about how to write noh plays, we can safely assume that he followed Zeami's principle of choosing source stories. Nobumitsu was the manager in the Kanze school. Nobumitsu was most likely to have easy access to Zeami's treatises. Thus, we can assume that both Zeami and Nobumitsu chose these plays' source stories because these stories and themes were familiar to patrons.

Zeami's Historical Background and Contexts

Zeami consistently depicted demons as having human qualities. He also included the demons' salvation and the pacification of their soul at the end of his plays. This dramatization emphasizes the unity between humanity and the demonic. In "Nikyokusantai Ningyōzu," Zeami states that although these roles have the appearances and forms of demons, their intent, or inner feelings to express, are human. ${ }^{56}$ As Yokomichi Mario put it, even the demons were human for Zeami.

In order to make this gentle demon relatable to the audience, Zeami utilized his new playwriting structure. Zeami invented the style of mugen noh 夢幻能, in which the ghost of the protagonist appears in the dream or vision that the waki actor's character

${ }^{56}$ Hare, p. 145. 
experiences. ${ }^{57}$ Like human ghosts in his other plays, these demons come to speak about their suffering to the passerby and ask for their sympathetic or redemptive assistance. The monsters want the waki characters to listen to them or pray for their salvation. Except for god plays, Zeami consistently depicted the inner suffering of these protagonists whether they were warriors, women, or demons. For Zeami, the structure of mugen noh is essential even when he wrote demon plays.

\section{Zeami's Childhood Training in Tōdaiji Sonshōin}

Zeami lived between 1363 and 1443. He enjoyed the patronage of Ashikaga Yoshimitsu (1358-1408) until his death in 1408. In 1375, when his father Kan'ami performed in the presence of Ashikaga Yoshimitsu at Imakumano shrine, Yoshimitsu noticed the talent and beauty of twelve-year-old Zeami (his name was Oniwaka at this time). ${ }^{58}$ Yoshimitsu frequently allowed Zeami to be present when Yoshimitsu attended public events. Yoshimitsu shared his seat with Zeami at the Gion festival and let Zeami drink from Yoshimitsu's cup. ${ }^{59}$ In the beginning of his career, Zeami was surely among Yoshimitsu's favorite actors.

As a young boy, Zeami had many talents in addition to performing noh. Thirteenyear-old Zeami had already been training in various arts and exhibited considerable talent in poetry and kemari when Yoshimitsu met Zeami. ${ }^{60}$ Kemari was a kick ball game that had been popular among Heian aristocrats. Zeami's proficiency in these aristocratic arts

\footnotetext{
${ }^{57}$ Pinnington, p. 106.

${ }^{58}$ Omote, Kanze-Ryū Shi Sankyū, p. 531.

${ }^{59}$ Pinnington, p. 106.

${ }^{60}$ Ogawa, p. 359.
} 
shows that his father Kan'ami had Zeami trained to impress Japan’s leadership elites. Although the details about his training as a youth are unknown, he was a chigo at Tōdaiji Sonshōin before he met Yoshimitsu at the age of thirteen. ${ }^{61}$ Chigo were acolytes who provided companionship in the medieval Buddhist monasteries. Older acolytes in their teens sometimes provided sexual service for older monks. These acolytes' service was often an apprenticeship for elite careers, either religious or secular. Yoshimoto and people in Yoshimoto's cultural circle praised Zeami's talent three years after they met. In this temple, Zeami seemed to have access to the training in high culture pastimes shared among the elite class. Nijō Yoshimoto was the leading scholar at Yoshimitsu's time and he was also Yoshimitsu's cultural mentor and mediator to the imperial court. Nijō Yoshimoto (1320-1388, 二条良基) wrote a letter addressed to Sonshōin praising Zeami’s natural beauty and talent in poetry and kemari games, calling Zeami "the return of Hikaru Genji" - the protagonist of The Tale of Genji. ${ }^{62}$ And, Yoshimoto gave the boy a new name, Fujiwaka, which proves the importance of their relationship. Yoshimoto chose the character fuji (藤, wisteria) from his own surname, Fujiwara. ${ }^{63}$ Probably, Yoshimoto himself advised Zeami on composing poetry. However, it is likely he was ready to absorb higher training from Yoshimoto because of this exposure to high culture earlier in his childhood. Growing up in this advantaged environment, Zeami would have become familiar with the aesthetics of the elite class.

\footnotetext{
${ }^{61}$ Matsuoka, Utage no Shintai, pp. 148.

${ }^{62}$ Matsuoka, Utage no Shintai, pp. 146-147.

${ }^{63}$ Pinnington, p. 107.
} 


\section{Zeami's Great Patron: Ashikaga Yoshimitsu}

Yoshimitsu, Zeami's major patron, was the unifier of the nation and the samurai leadership class. He was the third shōgun of the Muromachi bakufu. After ending the war state between the northern court and southern court, he strove to unify the nation by bringing the court and the samurai class bakufu together, as well as establishing the supreme sovereignty of Muromachi bakufu over the powerful regional samurai lords. Yoshimitsu was an active participant in court rituals, which his grandfather and father avoided as much as possible. These two shogūn avoided participation because of the complicated nature of court rituals. ${ }^{64}$ Yoshimitsu enjoyed these rituals more, and attended frequently. ${ }^{65}$ These rituals had the symbolic significance of publicly displaying the court ranking in a formal hierarchy. ${ }^{66}$ Yoshimitsu successfully gained the support of monarchy and courtiers who surrounded the emperor. Thus, Yoshimitsu was indeed the political unifier of the nation bringing together the two distinct parties in power.

Yoshimitsu is also known for being the founding patron of Kitayama culture. Kitayama literally means "northern mountain," which refers to the mountains north of Kyoto. Yoshimitsu established his residence and supporting cultural centers, such as important temples in this area. The culture which flourished there is commonly known as Kitayama culture (Kitayama bunka). Kitayama culture is characterized by the unification of the samurai elites' culture and the imperial court's culture. In terms of religious patronage, Yoshimitsu, like his shogunal predecessors, continued to support Zen institutions, but he also participated in the Shingon sect, favored by the old nobility and

\footnotetext{
${ }^{64}$ Ogawa, pp. 54-55.

${ }^{65}$ Ogawa, p. 90.

${ }^{66}$ Ogawa, p. 261.
} 
court elites. Yoshimitsu attempted to establish himself as a king, who combined the military power of the samurai class and the cultural power of the aristocracy. ${ }^{67}$ Kitayama culture was an important facet of his strategic project to unify the two distinct classes and their social customs and cultures.

Kitayama culture was significantly impacted by newly imported Chinese culture from the Ming dynasty (1368-1644). One of the most influential aspects was Zen Buddhism. The Kamakura bakufu had already imported some Zen teachings and practices to Japan and patronized several temples. However, Yoshimitsu formally patronized and privileged Zen Buddhism by establishing religious centers called the Gozan temples. Buddhist monasteries in the Muromachi period had enjoyed military, political, and economic autonomy for several centuries. They were exempt from paying taxes to secular authorities and had their own armies. Historically, the court and Kamakura Shogunate had problems with the militarization of Buddhist monasteries, such as Kōfukuji temple and Enryakuji temple. Yoshimitsu carefully utilized the newlyestablished Gozan system to monitor the status of militarization within Zen Buddhist monasteries. As the Gozan monasteries were newly established, Yoshimitsu regulated their assignment of abbots. Having these abbots on his side, he also could watch over his regional retainer lords (shugo daimyō 守護大名) and allied regional warrior lords (jitō 地 頭). For Yoshimitsu, these gozan monks and monasteries were also strategic allies because they often dealt with the administration of trade with the Ming dynasty. This trade brought Yoshimitsu the wealth and cultural assets that he could utilize for attracting

${ }^{67}$ Varley, “Cultural Life in Medieval Japan,” p. 461. 
more allies to the Ashikaga Shogunate. These monks were specialists in Chinese culture, including Zen Buddhism, literature, tea ceremony, pottery, and paintings. Yoshimitsu was very active in including these new aspects of Chinese culture into his cultural world.

Along with being the patron of these ongoing cultural endeavors, Yoshimitsu became the patron of the aspiring art form around this time: noh drama. Unlike other important arts, noh actors never had a great patron before Yoshimitsu. One of noh's formative events was the famous Imakumano Shrine noh performance in 1375. Yoshimitsu continued to support Kan'ami and Zeami while Kan'ami was alive. Scholars attribute the revolutionary style of Kan'ami's noh in terms of rhythmic singing of poetry and rhythmic dance, integrated into plays with enjoyable plot. These plot driven plays were part of Kan'ami's family performance heritage as well as Yamato sarugaku tradition. Kan'ami studied the rhythmic poetry singing and rhythmic dance under female kusemai performer Otozuru (dates unknown, 乙鶴) and later added them into his brand of noh drama ${ }^{68}$ Kusemai is a form of dance which has the same opening and ending verses. In kusemai, the performer sings poetry and dances. Kusemai performance was closely tied to shirabyōshi performance. Shirabyōshi was often danced on the same program which noh plays were performed. Both kusemai and shirabyōshi had clear rhythm. Kuse sections in noh plays used this kind of clear rhythm to provide the coherence in the singing by the chorus and other performers.

Yoshimitsu was a major patron of noh at this time. His values strongly influenced Kan'ami and Zeami's approach to their art. Unification and harmony are the hallmarks of

\footnotetext{
${ }^{68}$ Matsuoka, Nō: Chūsei kara no Hibiki, p. 60.
} 
Yoshimitsu's ethos. We see Yoshimitsu's ethos at work in Kan'ami's study with masters of different arts and his incorporation of those arts into his own drama. In Yoshimitsu's time, there was a peaceful performance of noh drama alongside disparate art forms.

\section{Emergence of Linked Verse and its Influence on Zeami}

In 1408, Zeami's main patron Ashikaga Yoshimitsu held a series of entertainment rituals, among which noh drama was a major component. According to diaries Norikoto Kyōki and Kitayamadono Gyōkōki, when the emperor Go-Komatsu (1377-1433) visited Yoshimitsu on this occasion, Yoshimitsu presented noh in a series of entertainments and rituals over twenty-one days, including bugaku (court dance and music, 舞楽) performance, kemari performance, shirabyōshi performance, renga poetry composition, and a waka poetry competition (和歌御会). ${ }^{69}$ When we look into the treatises on various forms of art around this time, we can see similar aesthetics in play. We can assume that these art forms influenced each other especially when the patron was the same individual. Various historical records show that Yoshimitsu indulged himself in linked verse composition gatherings with many illustrious participants. ${ }^{70}$ Renga 連歌 was the linked verse where the first seventeen syllable verse were composed by the facilitator, followed by poets who composed subsequent verses one after another until a set number of verses, such as one hundred, were composed. The fundamental rule is that a following verse should link with the previous one but cannot directly mimic the theme and vocabulary of the preceding verse. Renga was born out of the tradition of Japanese poetry. We can see

\footnotetext{
${ }^{69}$ Shimazu, "Tōza no Bungei," Chūsei no Bungaku, pp. 246-248.

${ }^{70}$ Ogawa, pp. 108-111.
} 
renga's significant influence on noh play scripts, which borrow, create and make reference to a large variety of Japanese poetry.

Yoshimitsu frequently sponsored renga gatherings. Yoshimitsu had a mentor for renga: Nijō Yoshimoto. Yoshimoto is well known as the compiler of Tsukubashū, the first anthology of renga poetry. He also wrote several treatises about poetry, which influenced Zeami's noh treatises. The letter from Yoshimoto to the abbot of Tōdaiji Sonshōin 尊勝院 shows that Yoshimoto knew that Yoshimitsu had begun to praise Zeami's beauty and artistic talent. Two linked verses that Yoshimoto and Zeami composed together are recorded in the emperor Sukō's diary Fuchiki 不知記. ${ }^{71}$ And, Yoshimitsu often composed the linked verse in Japanese and Chinese with Yoshimoto and other Zen monks as well. These frequent interactions show that Yoshimoto played a significant role in developing the cultural tastes of both Yoshimitsu and Zeami.

Yoshimoto was not only a leader who strove to revitalize the court and aristocracy after their loss of political power, but in his time he was also the leading scholar of aristocratic culture and especially poetry. By the 1360s, the bakufu held political power even though the samurai class respected the emperor and court. However, the old monarchy did not have much real-world authority because they had lost their financial base long before. ${ }^{72}$ Yoshimoto knew it was inevitable for the court to establish alliances with bakufu and samurai leaders to ensure its survival. He attempted to encourage Ashikaga Takauji, Yoshimitsu's grandfather, and Yoshiakira, Yoshimitsu's father, to get involved with the court rituals to facilitate a closer bond between the court and samurai

\footnotetext{
71 Tokue, "Zeami," Chūsei no Bungaku, p. 258.

72 Ogawa, p. 55.
} 
class. However, both Takauji and Yoshiakira avoided interacting with the court because of its complicated conventions of rituals. ${ }^{73}$ It was not until Yoshimitsu that the shōgun started to have a closer relationship with the court. Yoshimoto facilitated Yoshimitsu's rapid promotion in the aristocratic ranks. After becoming a gon dainagon (deputy counselor of the first rank, 権大納言) in 1378 and a konoe no daishō (chief cabinet secretary of internal affair, 右近衛大将) in the same year, Yoshimitsu was promoted to be Udaijin (Minister of The Right = Internal Affairs, 右大臣), equal in responsibility to Yoshimoto himself in $1379 .{ }^{74}$ This kind of quick promotion was exceptional, and could not have been done without help from a powerful aristocrat like Yoshimoto.

Yoshimoto became the mentor of the young shōgun Yoshimitsu, teaching him about court rituals and aristocratic culture. Yoshimoto was very careful to prepare the social occasions to please and encourage Yoshimitsu to be more active in participating in these rituals and interacting with the emperor and courtiers. ${ }^{75}$ Yoshimitsu enjoyed these gatherings far more than his predecessors had. The close relationship between the shōgun and his teacher had a great impact on his aesthetics. Yoshimitsu enjoyed composing poetry himself, and some of his poetry is included in the anthology, Tsukubashu. Yoshimitsu's aspiration was to absorb and integrate the cultural heritage of the aristocracy into the culture of his new military regime. The aristocrats had high esteem for the classic poetry from the Heian Period. Especially because the Heian poetry was

\footnotetext{
${ }^{73}$ Ogawa, p. 54.

${ }^{74}$ Ogawa, pp. 81-87.

${ }^{75}$ Ogawa, pp. 83-86.
} 
fundamental for composing poems in renga competition gatherings, cultural circles around this time had enthusiasm for these classic poetry. ${ }^{76}$

To appeal to these aesthetics impacted by the court cultures, Zeami wrote many plays emphasizing yūgen. Yügen 幽玄 is the mysterious and subtle beauty which comes out of the hazy surroundings filled with such colorless things as fog, rain, or cloud. ${ }^{77}$ It is the beauty of imagination, which is not expressed directly, but readers or audiences have to work hard to find. Audiences are moved by their active discovery of the beauty while the actors are singing and dancing using minimal movements. Medieval literature scholar Matsuoka states that there was a well-known example of yugen among the educated in the medieval period. It is a legend of romance between a king and a goddess in Wen Xuan 文選, an anthology of classical Chinese poetry and literature compiled in the Liang dynasty (502-557). In this legend, King Huai of Chu is on a pleasure visit in a resort area along Yangtze River in Sichuan Province. When he takes a nap, he sees a dream-like vision in which a lady appears and the king and this lady become engaged. When she reveals her identity as the goddess of Wushan region, she leaves the king, saying that she will appear in front of the king over the rocky cliff in the south of Wushan region, taking the shape of clouds in the morning and rain in the evening. In the next generation, King Qingxiang of Chu comes to this region and he is moved by the beauty of clouds moving over the rocky cliff. He asks his vassal about this landscape, and the vassal shares the legend of the dream romance between King Huai of Chu and the goddess of Wushan region. Yügen is this kind of beauty. Spectators must work hard to imagine the

\footnotetext{
${ }^{76}$ Pinnington, pp. 15-17.

${ }^{77}$ Matsuoka, Nō: Chūsei kara no Hibiki, pp. 76-77.
} 
mysterious, beautiful goddess beyond the hazy surroundings, just like clouds over the rock cliff in Wushan region. Zeami wrote some of his noh plays in this aesthetic tradition. This kind of noh was for those who had a refined taste, as Zeami explains in his treatises "Fūshikaden."78

In Zeami's demon plays, we never see the brutal combat between demons and humans on stage. The demons are depicted as having a human quality. In Nue, the nue monster, played by the shite actor, and the chorus sing about how he was killed in a combat with the warrior Minamoto no Yorimasa and his retainer in a story-telling manner. However, the nue monster dances solo to illustrate the battle, not with any other actors. The brutality of the scene is implicit, not explicit, and this characterization appeals to refined audiences who prefer yūgen qualities. In his noh treatise "Sandō," Zeami emphasizes this $y \bar{u} g e n$ quality as the supreme value of noh drama. ${ }^{79}$ He claims that $y \bar{u} g e n$ in the performance is the most important foundation that will enable noh performers and playwrights to thrive. Zeami's patron Yoshimitsu and his cultural mentor Yoshimoto appreciated yügen in noh plays, and in other arts forms as well. Zeami characterized his demons, as well as warrior ghosts and female ghosts, according to the aesthetics of his major patrons.

\section{Zen Buddhism in Zeami's Treatises and Demon Plays}

From his treatises, scholars speculate that after Kan'ami passed away, Zeami had a difficult time transforming himself into a successful actor and playwright because he

\footnotetext{
78 "Fūshikaden," Zeami Zenchiku, pp. 33-34.

79 “'Sandō," Zeami Zenchiku, pp. 137-138, 143.
} 
had lost his beauty of youth. ${ }^{80}$ He had fallen to Yoshimitsu's "number two" after Inuō (?1413), who was an Ōmi sarugaku actor known for his beautiful dance. ${ }^{81}$ So, Zeami adopted Inuō's tennyomai (dance of heavenly maiden 天女舞) ${ }^{82}$ to use in the climax of his plays. Tennyomai was an abstract dance which could be incorporated into plays ${ }^{83}$ about widely diverging subjects without the dance being changed. This integration of tennyomai contributed significantly to Zeami's creation of yügen noh. Tennyomai have evolved into noh dances that are performed to instrumental accompaniment only with no singing of lyrics. In Zeami’s plays, these dances are called maigoto (dancing section, 舞 事), and include dances such as jonomai (introductory dance, 序ノ舞) and chūnomai (moderate dance, 中ノ舞) and others. Prior to Zeami, Kan'ami brought in kusemai into noh drama. Combining kusemai with tennyomai helped Zeami create a new, sophisticated structure for noh plays.

Zeami emphasized $y \bar{u} g e n$ for writing noh plays. He states it is difficult to find $n o h$ actors with qualities of $y \bar{u} g e n$ in performance. Zeami states his father Kan'ami had these yūgen qualities and Zeami attributes Kan'ami's success in large part to these qualities. For Zeami, every aspect related to the noh should express yügen. This included acting, dance, physical movements, singing, use of poetic verses, costuming, and the performer's state of mind. Those who embody yügen qualities were court nobles, especially young noblewomen. Their graceful and beautiful body movements and use of poetic languages

\footnotetext{
${ }^{80}$ Matsuoka, Nō: Chūsei kara no Hibiki, p. 69.

${ }^{81}$ Matsuoka, Nō: Chūsei kara no Hibiki, p. 70.

${ }^{82}$ Matsuoka, Nō: Chüsei kara no Hibiki, p. 70.

${ }^{83}$ Yokoyama, pp. 170-198. Yokoyama explains the dances which have similar characteristics are now called maigoto 舞事. Maigoto includes jonomai 序ノ舞 and chūnomai 中ノ舞.
} 
are the examples he uses in his treatise "Fūshikaden." Zeami integrated kusemai in his noh plays as kuse sub-sections, where the central shite actor dances and sings to express the protagonist's thoughts and feelings. Zeami frequently used this dance section in all his plays, including demon plays which express the aesthetics of $y \bar{u} g e n$.

Zeami's understanding of yügen was strongly influenced by those who were in the cultural circle of Yoshimitsu. One of the major contributors was Nijō Yoshimoto. ${ }^{84}$ For writing both noh plays and treatises, Zeami used the aesthetics and vocabulary which were very similar to Yoshimoto's. They share use of source materials, famous geographical settings, and the music structure of jo ha kyu. Both emphasize the critical value of $y \bar{u} g e n$ qualities in compositions. In his linked verse treatises such as Renrihishō. Yoshimoto explains that one of the most important aspects of composing poetry is $y \bar{u} g e n$. For him, yūgen was largely characterized by gracefulness and relaxed nobleness. ${ }^{85}$ This derives from the poetry tradition since the Heian Period. Yoshimitsu and the warrior elites around him sought to acquire the cultural heritage of these aesthetics from the aristocracy. Zeami expressed this graceful and relaxed nobleness of yūgen even in his demon plays. In these plays, he manifested the ethos of unification between the court and warrior class.

After Yoshimitsu passed away, Ashikaga Yoshimochi became a next shōgun. Turning away from much of what his father Yoshimitsu had done, he was a great admirer of Zen Buddhism. His retainers followed his admiration of Zen tradition. Zeami was not an exception and prioritized Zen over other cultural traditions. Zeami incorporated

\footnotetext{
${ }^{84}$ Goff, pp. 35-41.

${ }^{85}$ Okuda, "Nijō Yoshimoto no Yūgen Ron," pp. 61-63.
} 
elements of Zen teachings into his plays from this time. In addition to this political shift, Zeami also had a personal reason to turn to Zen. When he attempted to write treatises about noh, none of the previous literary tradition had vocabulary he needed to describe what he wanted to transmit to his disciples. He borrowed much of his terminology from Zen writing.

This was Zeami's cultural environment when he wrote his demon plays. He was greatly influenced by Zen Buddhism, and by his rivalry with Inuō during middle and late stages of his career. Nonetheless, in his early career, Zeami had established his fundamental approach to choosing source stories and using pre-existing texts. These qualities of his plays appealed to Yoshimitsu early during the shōgun's patronage. For Zeami, demons with the human qualities reflect the ethos of Yoshimitsu's timeharmony and the integration of former adversaries into a new mutually supporting relationship.

Nobumitsu's Historical Background and New Importance for Waki Actors

In comparison to Zeami's characterization of demons, Nobumitsu depicted demons as having no human qualities and the resolution of conflict in his plays is to have warrior heroes kill the demons. This fondness for conquering the powerful supernatural reflects the different ideals of the samurai class in his era. The spectacular victories of powerful warriors was an artistic representation of action that samurai elites in the new violent period often had to achieve in their real lives.

\section{Sengoku: Incessant Samurai Strife and Nobumitsu's New Approach to Noh}


Nobumitsu's career was in its prime after the decentralization of power following the Ōnin war (1467-1477), which eventually lead to Japan's Sengoku Era in the late Muromachi period - the Age of The Country at War. Because of the relative decline of the Muromachi bakufu's power, there was no grand patron like Yoshimitsu for Nobumitsu and his Kanze school troupe. His patrons were shugo daimyō and jitō (regional warlords), and Buddhist monasteries. ${ }^{86}$ These two were closely tied together as regional warlords often sent their offsprings into the important posts within large monasteries. Later, these shugo daimyō turned into or were overthrown by sengoku daimyō when Japan entered the era of violent anarchy. Around this time in history, the overall social trend was gekokujo (下克上, rebellion against authority). During this period (1478-1568), ${ }^{87}$ there were many instances in which retainers took over their lords' positions by treachery, rebellion, insurrection, ambush, and assassination.

The ethos of this age was intense concern with and violent protection of personal and family honor.

Japan's medieval age was a time when private revenge ruled. The entire social lives of medieval people were darkly shrouded by primitivism. If we try to understand from today's perspective the actions of people of that time-for example, their hypersensitivity to personal insult, their potential for explosive anger, their instinct for violent conflict, their sense of impending death carried to the point of despair [...] Fights among people born into this kind of world, even if the result of trifling causes, quickly escalated into private clashes and private battles in which blood could only be cleansed by blood. Fights were propelled by personal anger and personal resentments. Far from joining battle for reasons of loyalty $(c h \bar{u})$ or rightness (duty) ( $g i)$, medieval warriors gambled their lives in combat as though responding to some great manliness that rose from deep within them. Moreover, exacting revenge for harm suffered in fights was their overriding ethical concern. ${ }^{88}$

\footnotetext{
${ }^{86}$ Pinnintgton, pp. 157-158, 162-164, 168-170.

${ }^{87}$ Varley, "Law and Precepts for the Warrior Houses," p. 421.

${ }^{88}$ Katsumata, Shizuo, "Sengoku-hō," Iwanami Kōza Nihon Rekishi, cited in Varley, "Law and Precepts for the Warrior Houses," p. 422-423.
} 
During this age, even Ashikaga shōgun had to monitor a different branch of his own family in the eastern provinces in the Kantō. ${ }^{89}$ In the Sengoku period, warlords had to build their castle on the highest place on the mountain so that they could monitor their own retainers, and defend against internal rebellion. ${ }^{90}$ Those who lived in the lord's own castle were often only his father, brothers, and closest relatives. These were the only people the lord thought he could trust. However, during this period, sons were killing their fathers and brothers were killing their brothers. A lord was not safe even in his own castle in the Sengoku period. Although there were hierarchies among lords and retainers, warlords could not trust their retainers without being extremely cautious all the time.

These warlords were sometimes assassinated even during rituals and renga gatherings by their retainers. ${ }^{91}$ This brutal age created very different ethos among samurai leadership. Anyone related to the ruling class needed to protect themselves even from very close vassals and own family members. This era was when private revenge was in the ascendant. $^{92}$

The Muromachi bakufu attempted to maintain its authority by setting up a legal system named Kenmu Shikimoku, which prohibited basara, or deviation from the norm and extravagant ways of living. ${ }^{93}$ The fact this article prohibits basara shows how prevalent it was in the Muromachi period. Basara activities were prohibited because of their association with gekokujō values and violence. ${ }^{94}$ One of exemplary basara daimyō

\footnotetext{
${ }^{89}$ Varley, "Law and Precepts for the Warrior Houses," p. 420.

90 Senda, Nobunaga no Shiro, Sengoku no Shiro wo Aruku. Senda and Yata, Noto Nanaojō Kaga Kanazawajō.

${ }^{91}$ Owada, pp. 196-199.

${ }^{92}$ Varley, "Law and Precepts for the Warrior Houses," p. 422.

${ }^{93}$ Varley, "Law and Precepts for the Warrior Houses," pp. 417-418.

${ }^{94}$ Matsuoka, Utage no Shintai, pp. 25-27.
} 
is Sasaki Dōyo (1296?-1373, 佐々木道誉). ${ }^{95}$ He overthrew the southern court along with Ashikaga Takauji and the northern court. Dōyo organized extravagant parties to entertain his guests. Dōyo organized a party in the outskirts of Kyoto on the same day of the renga competition gatherings organized by his political rival. He organized this party's spaces were filled with luxurious ornaments like rikka flowers, tiger skin mattress, and Chinese imported goods. ${ }^{96}$ People in the capital flocked to the party. He often provided music, singing, and dance, and organized renga gathering along with tea ceremony quiz contest (tōcha) to entertain guests. In order to win the favor from samurai lords who produced these kinds of events, noh playwrights needed to write plays that suited these extravagant styles of entertainment. Basara was a significant trend among the samurai class throughout the Muromachi period. Matsuoka states that basara behaviors were not only extravagance in attire but also excessive behavior directed against the established authorities. This trend was closely related to the gekokujō values. These warlords enhanced their power in their region by expanding the size of their armies, their agricultural yields, and commercial activities. ${ }^{97}$ By this period, there was an important shift in the economy through the use of coins primarily imported from China. This cashbased economy created a rising class of wealthy warlords who accumulated excess cash through monopolies, usury, and gambling. ${ }^{98}$ Nobumitsu wrote noh plays for warriors to present, making sure these plays reflect the heroism and martial prowess in the Sengoku Era. These warlords enjoyed other pastimes as well, including linked verse gathering and

\footnotetext{
95 Pinnington, p. 62.

${ }^{96}$ Matsuoka, Chusei wo Tsukutta Hitobito, pp. 33-34.

${ }^{97}$ Varley, "Law and Precepts for the Warrior Houses," pp. 421-422.

${ }^{98}$ Pinnington, pp. 11-13.
} 
tea ceremonies at which participants contested on their ability to appraise tea varieties. This kind of competitive tea ceremony was called tōcha 闘茶, and expensive prizes were provided. These warlords held events to demonstrate their power and impress their allies, rivals, and their own vassals. The stage spectacle of Nobumitsu's plays shares aesthetic qualities of extravagance with basara, and this is very different from Zeami's plays.

\section{Medieval Spiritual Belief: Resentful Spirits}

In addition to this ethos and practices of violent ambition and redress of grievances, other kinds of belief systems are represented in Nobumitsu's plays. In the Muromachi period, the samurai elites found it useful to receive validation for their violent ambitions from higher authorities such as emperors and deities of Shintō and Buddhism. If samurai lords had an order from the emperor, it was easier to persuade allies and their own vassals to fight for a just cause. Samurai at all levels conducted rituals to secure blessings from deities before battles. Leading samurai, who endeavored to secure both divine and imperial support included Oda Nobunaga, Tokugawa Ieyasu, Takeda Shingen, and others. ${ }^{99}$ In Momijigari, Koremochi receives the blessing and a divine sword from Hachiman deity, the Shintō god of war. The worship of these deities prior to battle was very important to these samurai elites in order to gain supernatural assistance and prevail against their enemies.

There is another aspect of Nobumitsu's demon plays, which has its roots in the folk tradition of belief in angry, resentful spirits (onryō shinkō 怨霊信仰 / goryō shinkō

\footnotetext{
${ }^{99}$ Owada, pp. 201-206.
} 
御霊信仰). This is the belief that the curse of resentful spirits causes natural disasters and epidemics. In order to overcome the curse of evil spirits, Japanese usually took two different approaches. One was to deify and worship them in order to pacify them. The best-known example is the deification of Sugawara no Michizane and his enshrinement as a deity at Kitano Tenjin shrine. ${ }^{100}$ The other approach was to conquer the spirit with the assistance of other powerful authorities: i.e. the emperor, Shintō deities, or Tantric Buddhist exorcism. Japanese literature scholar Haruo Shirane introduces one example from Konjaku Monogatarish $\bar{u}{ }^{101}$ The villagers in Ōmi Province were troubled by the curse of tree spirit when they attempted to cut down the large tree. Thus, they asked the emperor for permission to do so. With the imperial order, they could safely accomplish the felling of the tree.

The second approach had a great impact on Nobumitsu's playwriting. Because they themselves frequently fought in battles, the samurai elites were likely to praise the brave acts of powerful figures such as Taira no Koremochi in Momijigari, Watanabe no Tsuna in Rashomon, and Susanoo no Mikoto in Orochi as they kill evil demons. With the exception of Susanoo, the other two warriors were humans. However, they were able to win battles with powerful demons because they were fighting for the imperial cause, and with divine assistance. In this sense, these demon-killing noh plays present examples of righteous brave deeds by warrior heroes to protect the imperial realm from demons.

\section{New Importance of Waki Characters}

\footnotetext{
100 This legend is the source story of the noh play Raiden.

${ }^{101}$ Shirane, pp. 127-129.
} 
Nobumitsu lived two generations after Zeami. He was not a shite actor but a renowned drum player. Because the Kanze school already had younger main shite actors Kanze Yukishige and Motohiro, Nobumitsu supported them by being a Kanze troupe manager (権守 gon no kami). In addition to writing his treatises about drumming and singing, he wrote many noh plays. His plays are generally characterized by stage spectacle realized by energetic danced battles on stage, a larger number of actors, stronger presence of waki actors, and the inclusion of ai-kyoggen into the plot of the play.

These plays are said to have been performed by the young shite actors, Yukishige (d. 1500) and Motohiro (1472-1523). ${ }^{102}$ Scholars claim that in order to overcome this lack of an established, powerful shite actor in Kanze school, Nobumitsu wrote many plotdriven plays with more significant performances for waki actors. Comparing Nobumitsu's play scripts with Zeami's shows that the waki actors play a much more significant role in Nobumitsu's plays than in Zeami's plays.

\section{Zeami's Demons and Nobumitsu's Demons}

The ethos of the time of these playwrights had a significant impact on their plays because in order to win acclaim they had to affirm the core values of their most important patrons. Zeami's message in his demon plays is that apparent enemies can be reconciled. This is congruent with the unification of the court and samurai cultures that was central to Yoshimitsu's reign. Zeami used his new structure of mugen noh to depict human-like demons. Nobumitsu wrote plays using the conflict-centered source stories and they were

${ }^{102}$ Omote, Kanze-Ryū Shi Sankyū, pp. 562-563. 
enjoyable to the Sengoku-era samurai lords. Zeami wrote that pleasing the primary patron is crucial to the success of plays and productions. ${ }^{103}$ In this sense, both Zeami and Nobumitsu followed the same principles to make the plays enjoyable to their audience. For both playwrights, the primary audience was samurai elites. In Zeami’s case, Yoshimitsu was an exceptionally powerful samurai who stood on the top of hierarchy during his time, and profoundly influenced the ethos of the samurai under him.

The significant difference is the purpose of social entertainment rituals for these patrons. For Zeami's patron Yoshimitsu, noh plays were one cultural tool he used to unify the aesthetics of samurai elites and aristocrats, courtiers and royalty. These rituals and noh plays were the vehicles Yoshimitsu utilized in order to bring all the military, political and cultural power over to his side. For Nobumitsu's patrons, although there are not sufficient historical records, noh history scholars generally agree these plays were presented by samurai warlords and Buddhist monasteries. Sengoku lords presented spectacular large cast extravaganzas and conflict centered plays-fury $\bar{u}$ noh plays - to impress their own vassals, allies and potential allies with their wealth and prestige. The different audiences at these events, with their different values, defined the overall playwriting practice of our two authors.

In his seminal treatise "Fūshikaden," Zeami insisted that audience is the foundation of noh drama. ${ }^{104}$ Playwrights need to create characterization according to the audience's aesthetics and preferences. He also emphasized that playwrights should depict what is powerful as having graceful yügen qualities when audiences prefer $y \bar{u} g e n$.

\footnotetext{
103 "Fūshikaden” and "Kashū no Uchi Nukigaki," Zeami Zenchiku, pp. 27-29, 69-70.
}

104 "Fūshikaden," Zeami Zenchiku, p. 51. 
Playwrights need to create plays according to the audiences' aesthetics, which shift as time and trends change. Both Zeami and Nobumitsu took these principles very much to heart. Zeami and Nobumitsu characterized their demons very differently. Zeami created humanized demons with graceful yūgen qualities. And, Zeami treated them like humans because the inclusion of the Other including these non-human creatures was important social value among his patrons such as Yoshimitsu. Nobumitsu characterized demons as powerful antagonists who fight with strong warrior heroes. This exciting combat on stage suited social occasions produced by Nobumitsu's patrons. These two playwrights created very different demon plays according to different ethos and cultural tastes of their audiences. In the following chapter, I will explore how Zeami and Nobumitsu crafted the texts that form the core of their dramaturgy. 


\section{Chapter 3: Crafting Play Scripts for Demon Noh}

As presented in the previous two chapters, Zeami and Nobumitsu expressed very different ethos in their demon plays. They used various literary sources and techniques to craft their plays. Most significant are their source stories, role assignments, play structure, characterization of demons, and reference to and incorporation of pre-existing poetry and prose writings. I will examine all of these in this chapter. I will analyze the characterization along with reference to and incorporation of pre-existing texts because they are closely tied together in noh plays.

\section{Source Stories}

Zeami's demon noh plays are based on a war tale (Heike Monogatari), and regional legends. Yamanba also derives from a popular dance among courtesans on the theme of mountain hag. ${ }^{105}$ Nue's source story is from Heike Monogatari about a nue monster. In the tale a nue attacks the imperial palace, is shot down, and then thrown into the river. The story ends there, but the noh play is about the nue's reappearance as a ghost to tell of his suffering in hell. According to Sanari, Ukai is based on a regional legend about a cormorant fisherman's ghost appearing in a village where he was killed. Zeami's fourth demon play Nomori is based on the poetry treatise, Shüchūshō. Zeami seems to have chosen various stories about demons from a wide variety of sources for his noh plays.

I will examine the difference between the source story and Nue to illustrate how Zeami wrote his plays using these pre-existing stories. In the beginning of the play, a

\footnotetext{
105 Sanari, p. 3166.
} 
boatman appears. After the boatman reveals himself as a nue monster, he tells how he

was killed by Minamoto no Yorimasa and his retainer. The original text is following.

The following story tells of Yorimasa's highest attainment. During the Nimpyō era [1151-53] Emperor Konoe was haunted every night by a terrible spirit; and each time the spirit appeared, he became faint. He ordered high and noble priests of great experience to conduct great and secret ceremonies, but this proved useless. He was invariably possessed by the spirit at the hour of the ox [2:00 A.M.]. At that hour a mass of black clouds came from the direction of the wood of East Sanjō and hovered over the palace. The emperor became panicstricken. [...]

Yorimasa took with him only one of his hereditary retainers. This was Inohayata from the province of Tōtōmi, a man upon whom Yorimasa relied above all others. [...] Thus armed, he took up his post on the wide veranda of the Shishin-den and awaited the monster's coming. [...]

Looking up, Yorimasa saw in the cloud what appeared to be a monstrous form. He said to himself that if he failed to hit the creature, he would live no longer in this world, The firm resolution made, he took an arrow and spoke in his heart the invocation to the god of war: "Hail great bodhisattva Hachiman." Then he bent his bow with all his might and let fly. His hand sense that the arrow had struck home; he cried out; "Done!" Inohayata rushed out and seized the monster as it fell. He pressed it down and pierced its body nine times with his sword. Then many officials, both high and low, approached the spot with torches and gazed at the creature. What they saw was a terrible form with the head of a monkey, the body of a badger, the tail of a snake, and the feet of a tiger. Its voice was like that of a nue. $[\ldots]$

The emperor was so grateful to Yorimasa that he presented him with a famous sword called the King of Lions. [...] It is said that the monstrous creature was put into a canoe and sent adrift upon the sea. ${ }^{106}$

Just as the narrator in Heike Monogatari, the nue monster in the play takes the perspective of a third person when he describes his death and a detailed account of the imperial palace was prior to his attack. In the second act, the nue monster ghost returns in its true form. He confesses his guilt and repentance for attacking the emperor, and dramatically describes how he was killed during his attack. He describes how Yorimasa's arrow knocked him to the ground and how Yorimasa's retainer stabbed him to death with

\footnotetext{
${ }^{106}$ Kitagawa et al, The Tale of the Heike, pp. 280-281.
} 
his sword. Because Yorimasa prayed to Hachiman deity, the nue monster admits it was divine punishment that he had to be killed by Yorimasa and his retainer. ${ }^{107}$ When the nue monster talks about the emperor, he uses the honorific form of speech.

$\begin{array}{ll}\begin{array}{l}\text { Sunawachi go-nō } \\ \text { shikiri nite } \\ \text { gyokutai o }\end{array} & \begin{array}{l}\text { whereupon a pain become } \\ \text { acutely frequent, } \\ \text { his noble person } \\ \text { nayamashite } \\ \text { obie- }\end{array} \\ \text { tama irase- } & \begin{array}{l}\text { and terror } \\ \text { that made him tremble; }\end{array} \\ \underline{\text { tamō koto mo }} & \text { and all these things, he said, } \\ \text { waga nasu waza yo to } & \text { were of my evil doing too. } \\ \text { ikari o nashishi ni } & \text { As I boasted all in fury, }{ }^{108}\end{array}$

Here, words, gonō 御悩, gyokutai 玉体, tamairase 魂いらせ, and tamau (tamō) 給ふ, are spoken in the honorific form of Japanese language and used in reference to the emperor Konoe. This respect for the emperor, whom the monster attacked when it was alive, shows the nue monster's repentance. Now he honors the emperor even though he tried to kill him many years ago. Throughout the play, the nue monster is a regretful and calm creature whether he is disguised as a boatman in the empty boat or appearing in his true form. Using an original source story, Zeami transformed the narrative of a war hero's victory into the narrative of a repentant monster. Inspired by the Buddhist tenet “Attainment of Buddhahood of Vegetation and Earth” (sōmoku kokudo shikkai jōbutsu 草 木国土悉皆成仏), Zeami created a nue monster with having human qualities and the ability to communicate in a human language. In Mahayana Buddhism, if we all can attain

\footnotetext{
${ }^{107}$ Here, I translated Hachiman Bodhisattva 八幡大菩薩 as Hachiman deity. In the belief of honchisuijaku 本地垂迹, many Japanese Shitō deities are considered to be the embodiment of Buddism bodhisattva. Hachiman Boddisattova is basically Hachiman deity here.

${ }^{108}$ Yasuda, pp. 433-434.
} 
a buddahood, then monsters can. For Zeami, through the power of Buddhism, even these monsters in his plays can realize Buddhist wisdom and became a buddha.

Nobumitsu's three demon noh plays were based on a regional legend, a war tale ("Tsurugi no Maki" in The Tale of Heike), and Japanese mythology. Momijigari is based on a regional legend of a demon who lived in the mountains. Rashōmon is based on a story in The Tale of Heike although Nobumitsu changed the location of the demon's appearance from a bridge in central Kyoto to the Rashōmon gate. Orochi is a famous tale about a serpent monster in Nihon Shoki and Kojiki, Japan's oldest mythology. There are other demon plays by Nobumitsu, which are based on Chinese paintings (Ryōko 龍虎) and setsuwa narrative of a temple (Kanemaki 鐘巻). Thus, Nobumitsu also took his stories from diverse sources.

Nobumitsu's Rashōmon is a modified version of a demon's story in Heike Monogatari, and Konjaku Monogatarish $\bar{u}$. The demon shows up at the bridge in the original text. The Ichijō Modoribashi bridge is right by the imperial palace.

At that time, the Governor of Settsu Minamoto Raikō, had powerful retainers, The Four Heavenly Kings: Watanabe no Tsuna, Sakata no Kintoki, Usui no Sadamitsu, Urabe no Suetake. Among them, the strongest was Watanabe no Tsuna. [...]

The lord Raiko dispatched Watanabe no Tsuna to Ichijō Ōmiya for an errand. Because it was late at night, Raikō gave Tsuna a great sword Higekiri (Beard Slayer) and made him ride a horse to go. After completing his task, Tsuna was about to pass by the Modoribashi bridge over the Horikawa stream on 1st Avenue. There was a beautiful woman around twenty-years-old with fine skin white like snow, wearing a red plum dress. Without any company, she was going south. When Tsuna was about to pass the east end of the bridge, she clapped her hands and abruptly said, "Where are you going? I am from near Gojō, but would you please escort me because it is scary at midnight?" Tsuna immediately dismounted from his horse, and offered her to put her on his horse. The woman was delighted, so Tsuna approached and held her to help her mount his horse. They went southward together. When they got near Ōgimachi, the woman looked back and said, "Actually, I do not have any business to do near Gojō. My house is 
outside of the capital, so would you escort me there?" Tsuna said, "Certainly. I can take you anywhere you wish." When the woman heard Tsuna said so, she changed her form and became a horrifying demon and says, "Let's go. My destination is Atago Mountain." The demon seized the topknot on Tsuna's head and flew into the air of North-West. Without making a fuss, Tsuna quickly drew the fine sword Higekiri and facing upward, he slashed off one of the demon's arms. Tsuna fell down to the roof of the corridor of Kitano Tenmangū Shrine, while the demon kept flying to Atago Mountain, without one of her arms. Then, Tsuna jumped down from the corridor and took off the arm of the demon grasping his topknot. The arm was unlike the snow-like white fine skin of the woman-it was dark black with white hair all over it sticking out like silver needles. When Tsuna brought back the arm of the demon to Raikō, Raikō was surprised and found it very mysterious. ${ }^{109}$

Here, Tsuna helps a young lady who is scared as she tries to pass by the bridge. The young lady is a demon who disguises herself as a lady. She reveals herself as a demon after she gets on Tsuna's horse and goes together with Tsuna. This detail of a demon disguised as a young lady is delited from Nobumitsu's play. In Nobumitsu's play Rashomon, the demon appears out of the darkness in the form of a demon. Also, the location has changed. The demon appears at the Rashōmon gate. For some reason, Nobumitsu preferred to use the gate as the demon's den. The gate is at the southern entrance to the capital of Kyoto. The significance attached to the Rashōmon gate is protection from evil spirits that might enter from the south on the widest street in the city, Suzaku Ōji Avenue (朱雀大路). This avenue leads directly to the imperial palace. If a demon dwells in this gate, loyal retainers of the emperor had to do something about it. Nobumitsu created a compelling reason for the waki character Tsuna fight with the demon. Prior to Nobumitsu's play, there was no literary work that describes Watanabe no Tsuna encountering a demon at the Rashōmon gate. This version of the story of the

\footnotetext{
109 Translated by the author. "Tsurugi no Maki," Heike Monogatari, pp. 4-5.
} 
demon became famous because of Nobumitsu's play. Zeami, in his treatises, wrote that the audiences should have some knowledge about the material they see on stage. The success of Nobumitsu's play suggests that there was enough knowledge about Watanabe no Tsuna and the Rashōmon gate for Nobumitsu's new revised version to resonate with audiences.

This version of the story became famous thanks to Nobumitsu's plays. By the mid-Edo period, all Japanese knew that Watanabe no Tsuna fought a demon at the Rashōmon gate, and the demon acquired the name, Ibaraki-dōji. As we see in the case of the Rashōmon demon above, some stories depicted in demon noh plays became highly popular and widely known. Nobumitsu's Momijigari is another example. It is impossible to determine what audiences knew prior to the first presentation of these plays. We can assume some familiarity with earlier legends about these characters.

Zeami and Nobumitsu took different approaches to crafting their plays using these source stories. Except for Orochi by Nobumitsu, Zeami and Nobumitsu changed original source story plots considerably in their noh plays. In Zeami's plays, the thrust of his narrative was progressive revelation of demons' human qualities. Nobumitsu changed stories and characters to facilitate spectacular staging of his plays. In some cases, these two authors' plays became the most popular version of these stories.

\section{Zeami's Role Assignment}

There are several kinds of actors in noh plays. The shite actor is the actor who plays the most important role in the play. He specializes in poetic singing and dancefocused acting. Shite-tsure シテツレ, or tsure ツレ, are other actors who are from the 
same school as the shite actor. The waki actor is the actor who plays the most important supporting role. He specializes in straightforward acting and expressive speech in prose form. Waki-tsure ワキツレ are other actors who are from the same school as the waki actors. Omoai オモアイ, or ai アイ, is the main kyōgen actor, who speaks in expressive and plain language in noh plays. Kyōgen actors perform in kyōgen plays, or comical theater, as well. However, in noh plays, their lines are not necessarily comical, but they are rather narrative and descriptive, couched in what was close to the daily speech of the time. Adoai アドアイ, or ai アイ, are other secondary kyōgen actors of the same school. $^{110}$

Zeami's role assignment in his demon noh plays is strictly in accordance with his principle of putting the shite character at the center of a play. Zeami wrote his other plays, including god plays and warrior plays in the same way, focusing on his shite characters. Typically, the waki actor plays a traveling priest, an exorcist, or an imperial envoy. Therefore, waki actors play supporting stock characters. Their primary role is to encounter the demon and to listen to its story of suffering. Waki characters are the mediators who enable audiences to enter the world of demons and explore the demons' soul. In the jo and early ha sections of Zeami's plays, the waki leads the audience step by step from the normal temporal world in which they live today into the world in which time and space are malleable and in which normal humans can witness the supernatural. Although priests played by waki actors are humans, their religious training enables them to encounter the supernatural either intentionally or by chance. The profession of these

${ }^{110}$ Yokomichi et al, Nō no Kōzō to Gihō, pp. 229-231. 
monks is to deal with the divine and occult. Many setsuwa narratives include traveling monks who hear strange regional legends, including demon legends. Setsuwa writers indeed collected these stories while traveling and preaching the way of Buddha wherever they went. Travelers including monks went beyond the borders of human realms. Thus, they were more likely to experience these supernatural phenomena. Zeami's waki characters in demon plays are the representation of these anonymous traveling priests.

In comparison to waki characters, Zeami emphasized the dominant role that shite actors must play in his noh plays. For Zeami, the success of performance all depends on how well the shite performs. ${ }^{111}$ This is central to Zeami's approach to both playwriting and performance. And, it was his shite-centered noh that defined the genre and enabled him to acquire the patronage from the Muromachi bakufu, including the Shōgun Yoshimitsu.

In Nue, the shite plays a boatman in the first half, and the nue monster's ghost in the second half. The waki plays a traveling priest in the entire play. After the waki priest comes on stage, the priest encounters a villager, played by a kyōgen actor, who also plays the same role in the ai-kyoggen later in the play. The priest asks for a place to stay but the villager refuses to offer one because of a local regulation prohibiting accommodation for strangers. The villager reluctantly offers to let the priest stay in a temple building. After the waki has arrived in the scene and the shite arrives and we begin to learn who the shite character is, the waki character does not talk much more. The waki and the kyoggen actor set the scene in which the main character will soon appear. When the priest is spending the night at the temple, a boatman played by the shite actor appears on the water in front

111 Takemoto, p. 145. 
of the temple. The shite reveals his identity as the ghost of nue monster and starts to tell how the nue was killed by Minamoto no Yorimasa and I no Hayata. From here onward, the waki speaks fewer lines, and he listens to the story told by the ghost of the nue monster. In the second act, the shite plays the ghost of the nue monster in its true form, having a monkey's face, a Japanese raccoon dog's body, tiger's feet, and a snake as its tail. The nue moster is described in this way, but the noh actor wears a decorative costume. The shite actor dominates the stage, both singing and dancing.

In Yamanba, the shite plays the role of a village woman in the first half, and a mountain hag in the second act. The waki actor plays a traveling samurai throughout the play. He is accompanied by several companion samurai (waki-tsure) and a courtesan. The courtesan is played by the tsure actor. Normally, the tsure is a companion to the shite character, not to the waki character. The waki-tsure never wear masks, but this story requires a traveling courtesan, who is a woman, and women characters must be masked. Therefore, contrary to typical practice, the tsure accompanies the waki and his party. In Yamanba, she comes on stage along with the waki's character. Zeami needed this courtesan to create a scene in which she, a human woman, dances with the mountain hag. Kyōgen actors play anonymous characters who establish the basic setting of scenes in Zeami's three demon plays. All the three plays have one scene in addition to aikyōgen. In all the scenes kyōgen actors appear, the kyōgen actor and the waki actor speak together in dialogue.

In the first half of Yamanba, the kyoggen actor plays a local man who guides a traveling courtesan and the men to Zenkōji temple. When the waki character asks for the way to get to Zenkōji temple, the kyōgen character and waki character engage in a 
conversation. The kyoggen character explains there are three different routes to get to Zenkōji temple. One route is a tough mountainous way that those who attained

Buddhahood (nyorai 如来) walked before. This route is too difficult for women including the courtesan to use. There is no way for her to travel by carriage through the mountain. Without this guiding local man, the plot cannot move forward.

In both Nue and Ukai, this additional kyōgen scene in the first act provides the same situation for waki traveling monks. As we can see in the dialogue in Nue and Ukai, these two dialogues in the first act are identical to each other. Although there are minor changes in the name of landscape and temple buildings, what the characters discuss is basically the same. For example, in Nue, the villager explains there is the village's regulation prohibiting providing lodging for travelers.

About that question, there is an immutable law here that prohibits giving any lodgings to travelers. We cannot accommodate you. ${ }^{112}$ その事にて候。この所の大法にて。往来の者に宿貸すことは禁制にて候 間。なり申すまじく候。 ${ }^{113}$

In Ukai, the villager explains the same regulation to the waki traveling monk. The village rule and the text are identical.

We would like to offer you accommodation. However, there is an immutable law here that prohibits giving any lodgings to travelers. We cannot accommodate you. $^{114}$

尤も泊め申したく候へども。この所の大法にて。往来の者に宿貸すことは 禁制にて候間。なるまじく候。 ${ }^{115}$

\footnotetext{
${ }^{112}$ Yasuda, p. 418. Underline added by the author.

113 Sanari, p. 2380.

114 Translation added by the author, borrowing the large section of the translation in Yasuda.

115 Sanari, p. 300.
} 
The underlined clauses in the two quotes are identical. These identical texts provide three essential pieces of information. One is that villagers are prohibited by local regulation from offering lodging to travelers including monks. Second, there is a haunted temple building, where a strange shining object appears at night. Third, the monk can stay at this temple building because he has the protection of the Buddhist law.

Scholars speculate that Zeami wrote Nue after Ukai. ${ }^{116}$ Considering waki-kyōgen dialogues play the same role in both plays' plots, Zeami probably reused the entire wakikyōgen section in Ukai when he wrote Nue. These dialogues allow the waki priests to spend a night in a haunted temple building. Just as waki characters had a specific function, Zeami created a special function for his kyōgen characters as well. Although waki actors have more lines, kyōgen actors share supporting function with waki actors.

As shown above, Zeami clearly distinguished the different functions played by three different kinds of actors: the shite actor, the waki actor, and the kyogen actor. For Zeami, the shite actor was the center of all his plays and everyone else including waki actors and kyōgen actors supported the shite actor's performance. Because Zeami was noh's leading dramatist and theoretician and his approach became orthodoxy, we take this situation for granted as a modern spectator. However, in his early career, Zeami was an exceptional playwright, who established these new role assignments, creating a novel approach to writing noh plays.

Nobumitsu's Role Assignment

${ }^{116}$ Matsuoka, Nō: Chūsei kara no Hibiki, p. 119. 
Nobumitsu, on the other hand, did not follow Zeami's approach to role assignment. Zeami's plays continued to be frequently performed plays after his death, and many were considered masterpieces. The orthodoxy of shite dominated plays mentioned above was his invention. However, Nobumitsu had very different approaches to assigning specialized functions to different kind of actors, including the shite actor, the waki actor and the kyōgen actor. Nobumitsu was unrestrained by Zeami's treatises and conventions. While Nobumitsu's shite actors play major roles as demons, his waki actors play much more important roles in his plots than they do in Zeami's plays. They are not anonymous stock characters like Zeami's waki characters. ${ }^{117}$ They have their own identities. Indeed, they are famous personages: legendary warrior heroes (Taira no Koremochi and Watanabe no Tsuna) and a deity (Susanoo no Mikoto). These characters have their own legends in Japanese literary tradition. Nobumitsu consciously chose to use them as supporting characters who are of nearly equal status to the characters played by the shite actor, and provided them very important functions in the plot. Nobumitsu recognized that if drama of conflict was going to be central to his demon plays, he needed the antagonist of equal stature.

The shite actor plays two roles in Orochi. They are Tenazuchi, the elderly father of Kushinada in the first half, and Yamata no Orochi in the second half. These characters are not related to each other, unlike Zeami's plays or Nobumitsu's Momijigari, in which the demons reveal their true identities as demons in the second half. In comparison to the shite's two distinct roles in Orochi, the waki actor plays the single role of Susanoo no Mikoto in both acts. This waki character engages in the plot in a more active fashion than

\footnotetext{
${ }^{117}$ Some Zeami’s waki characters have clear identities such as Renshō in Atsumori.
} 
Zeami's waki characters, who simply observe and listen to what demons have to tell. The waki character Susanoo comes down to the Izumo Province and finds the old couple crying over the forced sacrifice of their daughter to a powerful serpent, Yamata no Orochi. Susanoo suggests helping the old couple by killing this serpent in exchange for marrying their daughter, Kushinada. Susanoo actively creates a trap for the great serpent and successfully conquers it. Without his active involvement, the plot of this play does not proceed. Unlike Zeami's passive waki character, this active involvement is one of the clear differences in Nobumitsu's demon plays.

Another distinct feature of Susanoo no Mikoto as a waki character is the fact that he is a deity in Japanese mythology. This is very different from Zeami's role assignment of waki actors. Zeami usually does not give individual identities to his waki characters. They are traveling monks or traveling warriors. Susanoo was worshiped as a deity in such shrines as Yasaka shrine in Kyoto, and several shrines in Shimane Prefecture. Susanoo was also considered to be the ancient example of a warrior hero in Japanese literary tradition. In mythology, he continuously conquered the evil monsters who troubled the land of the Japanese archipelago. However, unlike other human warrior heroes who were powerful during their lifetimes and get deified after their death, Susanoo is clearly depicted as a divine descendant of deities from his first appearance in mythology. He is often called the brother of the sun goddess, Amaterasu Ōmikami, chief deity of the Yamato gods. Thus, Nobumitsu consciously chose this important deity in Japanese tradition as a waki character instead of making this deity the shite character and using him as a single central focus as Zeami would have. 
The play Rashōmon has even more exceptional role assignments. The shite does not even appear in the first act. The shite actor only appears in the second act, playing the role of a demon who dwells at the Rashōmon gate. The shite does not speak or sing even one line on the stage. After the waki's character Tsuna defeats the demon by cutting off its arm, the demon flies away saying, "I will wait for the opportunity to get back my arm." The demon speaks only this one line but even this line is sung by the chorus. The actor just engages in the fierce battle with the waki actor's character in the second act. This is contrary to Zeami's treatises because for Zeami, the singing of beautiful verses was a critical part of the shite's performance. This silence hinders the shite's ability to create his presence on stage.

In contrast, the waki actor plays the role of Watanabe no Tsuna throughout the play in both acts. Tsuna plays an active role in advancing the plot as Susanoo does in Orochi. Tsuna engages in a dialogue with his master Minamoto no Raikō, other retainers and Fujiwara no Yasumasa at the banquet, and he starts an argument with Yasumasa. Yasumasa told the group about the rumor of a demon in the Rashōmon gate who is scaring people away from the gate at night. The demon is an affront to the peace of the imperial capital. This angers Tsuna and he sets off to the Rashōmon gate to investigate the gate. He is going to defeat the demon at the Rashōmon gate if the demon actually dwells there. In the second act, after he examines the gate, he encounters the demon and defeats her. Without Tsuna, the plot does not proceed. In this play, Nobumitsu created a plot in which the waki actor is one of the central characters. Tsuna's function in this waki role is almost identical to that of Susanoo in the play Orochi. The only difference between Tsuna and Susanoo is that Tsuna is a human while Susanoo is a deity. Among 
the three plays I examine in this thesis, Tsuna is the exception that he can defeat the demon without divinity or divine assistance. The only external element to empower him is the fact that he fights for the righteous cause of protecting the emperor's capital city of Kyoto. These plays show that given divine assistance or a righteous cause, warriors could defeat even powerful supernatural beings in addition to their human enemies.

In Momijigari, the shite character plays a beautiful noble lady in the first act and the demon in the second act. Momijigari's shite actor plays conventional function which is comparable to Zeami's shite actor's role. The demon appears as a human in the first act and reappears in her true form as a demon in the second act. The difference between Zeami's human-like demons and the demon in Momijigari is their characterization. The demon in Momijigari impersonates a cultured noble lady who appreciates natural beauty, can cite classical poetry, and perform a splendid dance. After she comes back as a demon at the beginning of the second act, she never speaks human language again and attempts to attack Koremochi. This is contrary to Zeami's demons who express their suffering in the second act. Nobumitsu's demons do not express their suffering in the second act. Instead, the demon is treated as a creature who does not communicate with people and intends to harm humans without any explanation. In the ai-kyōgen section of Momijigari, a servant deity of Hachiman god explains that Koremochi is on a journey to conquer a demon in Togakushi mountain. However, this demon does not seem to know Koremochi is there to kill her, nor did Koremochi mention his mission in his self-introduction. Apparently, the demon just tricks and kills passersby for no discernible reason.

The waki plays the role of Taira no Koremochi in both the first act and second act. In the first act, Koremochi appears with his retainer. Koremochi mentions that he is out in 
the mountains to go deer hunting. When Koremochi notices the drapery and $b y \bar{o} b u$ folding screen of somebody's banquet, he sends his retainer to ask who they are. After Koremochi finds out it is a noblewoman viewing autumn leaves, he dismounts from his horse and attempts to walk at a discrete distance from the drapery and $b y \bar{o} b u$ folding screen. The chorus praises how polite and sophisticated Koremochi is. This detail emphasizes Koremochi's noble character, which never happens for waki characters in Zeami's demon plays.

Compared to Zeami's plays, kyōgen actors have a specialized function in Nobumitsu's plays. Nobumitsu never placed any scenes in main texts where kyōgen actors appear on the stage. Kyōgen actors only appear on stage during ai-kyōgen section. In Momijigari, the kyoggen actor plays a servant deity of Hachiman god. All three of Nobumitsu's kyōgen characters have monologues but only the sub-deity in Momijigari plays an important role in forwarding the plot of the play. They do not necessarily speak directly to the audience, but they are mediators for the audience. I will examine this aspect of role assignment later in this chapter when I examine the use of ai-kyogen section.

When we examine the role assignments, we can see that Nobumitsu's plays deviated significantly from Zeami's conventions. All three waki characters have strong identities as legendary warrior heroes or a deity. Rashōmon is an exceptional play in that the shite only appears in the second act and never sings or speaks. Demons in Nobumitsu's plays do not speak human language, which means that there are much fewer opportunities to sing beautiful verses for the shite actors. The waki characters in these plays hold equal significance as the shite's demon characters. Some scholars speculate 
that this was a means for Nobumitsu to compensate for the young, unestablished shite actors who performed in his plays. Being a manager of the Kanze school, Nobumitsu should have been familiar with the conventions Zeami had established. However, Nobumitsu wrote plays breaking these rules. He did this for two primary reasons. One was that the core value of his samurai patrons changed significantly since Zeami's time. The second was his shite actors were younger and not as capable of successfully portraying emotionally complex characters. It is clear that they must have been very good at energetic dance.

\section{Structure}

Zeami and Nobumitsu had their own approaches to constructing plays. Zeami continued to use noh's tradition, his father Kan'ami's rhythmic singing and dance, and later adapted Inuō's abstract dances. Zeami placed these components strategically in each section of his plays. Nobumitsu sometimes followed what Zeami had created and had put into practice. However, Nobumitsu added energetic fight dance sections at the climax of all his demon plays.

Noh plays are composed of various dan 段 and shōdan 小段: sections and subsections. Dan, or sections, are scenes in each act. Several dan combined together to comprise an act, $b a$ 場. Typically, the shite character changes appearance between the first and second $b a$, during which there is an ai-kyōgen interlude. Noh plays are composed of either one act or two acts. ${ }^{118}$ Within the dan, the shôdan have important,

\footnotetext{
118 Yokomichi, Nō no Gihō to Kōzō, p. 329.
} 
specific functions. I will examine each shödan of demon plays in order to find out how Zeami and Nobumitsu created structures for their demon plays.

\section{Structure in Zeami's Plays}

In order to compete with an eminent noh actor named Inuō, Zeami adapted tennyomai, the dance of heavenly maidens, into his dramaturgy. This dance was Inuō's forte and he performed it often. This kind of dance is now known as maigoto. Zeami's father Kan'ami integrated kusemai (an independent dance) into noh drama. Zeami utilized kuse dances as the central dance in his plays. These dances are carefully integrated into the structure of Zeami's demon noh plays.

Yamanba is an example in which we can clearly see how Zeami integrated his playwriting technique and different dances into his plays. Here are the sections (dan 段) along with major sub-sections (shōdan 小段) in the play Yamanba.

Table 1. Dan Sections in Yamanba

\begin{tabular}{|c|c|c|}
\hline Dan & Events & Major shōdan \\
\hline 1 & $\begin{array}{l}\text { The courtesan and her traveling companions enter the } \\
\text { stage }\end{array}$ & \\
\hline 2 & $\begin{array}{l}\text { The traveling companion, a local man, and the courtesan } \\
\text { engage in dialogue }\end{array}$ & Mondō dialogue \\
\hline 3 & $\begin{array}{l}\text { The village woman, the traveling companion, and a } \\
\text { local man engage in dialogue }\end{array}$ & Mondō dialogue \\
\hline 4 & The village woman leaves the stage & Kakeai shared monologue \\
\hline- & $\begin{array}{l}\text { Ai-kyōgen: A local man tells a humorous and inaccurate } \\
\text { story about the origins of the mountain hag }\end{array}$ & \\
\hline 5 & The courtesan and the travel companion wait & \\
\hline 6 & The mountain hag enters the stage & \\
\hline 7 & The mountain hag and the courtesan engage in dialogue & Kakeai shared monologue \\
\hline
\end{tabular}




\begin{tabular}{|l|l|l|}
\hline 8 & The mountain hag and the courtesan engage in dialogue & Kakeai shared monologue \\
\hline 9 & $\begin{array}{l}\text { The mountain hag performs "The Mountain Hag's } \\
\text { Kusemai" }\end{array}$ & Kuri, sashi, kuse \\
\hline 10 & $\begin{array}{l}\text { The mountain hag performs dance movement to depict } \\
\text { her life in the mountains }\end{array}$ & $\begin{array}{l}\text { Utai songs, tachimawari music and } \\
\text { dance }\end{array}$ \\
\hline 11 & Finale & Shite actor's singing, chorus singing \\
\hline
\end{tabular}

Source: Yokomichi and Omote, Yōkyokushū Jō, pp. 275-287.

Most shōdan exist in three forms: movement, music, and text. Some shōdan such as mondō dialogues do not have music and active dance movements. Kuri, sashi, and kuse are three shödan most of time written in this sequence, which comprise one dan, in this case, the tenth dan. They are used for important dance sections. Kuse is rhythmic music and kusemai dance integrated into noh plays. It is sung following a clear rhythm. Most of the kuse texts are sung by the chorus, with the shite singing two to three lines. Kuse has two forms. The typical kuse is accompanied by the shite's dancing. In the iguse (seated kuse, 居グセ), the chorus and actor sing and there is no dancing. Kuri クリ is an introductory singing section, which is usually composed of several verses and sung in a smooth manner. Sashi サシ is a singing section which depicts landscapes, character's thoughts and emotions. This section is not sung following a set rhythm but sung in a smooth manner. These dances and songs advance the plot forward, thanks to the semantic contents of the lyrics and the mimetic and symbolic contents of the dance. In Yamanba, there is a kuse dance by the mountain hag in the second act. In this kuse dance, the mountain hag describes how she suffers living in the mountains. After the first line sung by the shite actor, the chorus takes over her verses while the shite actor performs the kuse dance. After the mountain hag's kuse dance, there is a concluding dance (tachimawari 立 
回り) by the mountain hag. Tachimawari is a form of hatarakigoto 働事, a dance which depicts characters' emotion or actions. ${ }^{119}$ This dance does not have any singing accompanying the dance, just instrumental music. Zeami utilized this tachimawari section as the climax in several of his plays. In Yamanba, Zeami not only utilizes kusemai, which was introduced by his father Kan'ami, but also included hatarakigoto, concluding this demon play. Both kuse and tachimawari are danced solo by the shite actor. Zeami used these dances to create his portrayal of human-like demons.

Zeami also utilized lively dialogues in various sections both in the first and second acts of Yamanba. These are called mondo (問答, questions and answers dialogue) or kakeai (掛合い, sung shared monologue). Mondō is a spoken dialogue section between two actors in prose form, which does not include any singing and does not follow a rhythmic score. Kakeai is a sung poetic shared monologue either between two actors or between one actor and the chorus. This section also does not follow a rhythmic score but is sung, not spoken. In Yamanba, Zeami utilized two mondō sections and one kakeai section in the first act, and two kakeai sections in the second act. Both mondō sections have kyoggen actors in the dialogue. These dialogues provide the reason for the waki character and the courtesan to take a difficult mountainous route to get to Zenkōji temple. These sections are important to create a landscape for the encounter with the village woman on the mountain.

The kakeai section in the first act is between the village woman and the courtesan. The village woman requests the courtesan to perform "The Mountain Hag's Kusemai"

${ }^{119}$ Yokomichi et al, Nō no Kōzō to Gihō, pp. 336-348. 
(山姥の曲舞). However, the village woman disappears after promising to come back in her true form as a mountain hag. Kakeai sections in the second act establish the scene where the mountain hag encourages the courtesan to perform "The Mountain Hag's Kusemai." After the courtesan starts singing for the kusemai, the mountain hag takes over the performance in the kuse dance section. In the audience's imagination, the mountain hag and the courtesan are supposed to be performing together. However, it is only the shite actor who dances on stage. Zeami utilized these kakeai sections to set the scene for the major kuse dance section and tachimawari section.

Another important aspect of these kakeai sections is that these kakeai are between the shite actor and the tsure actor. The tsure actor plays the courtesan. In Nue and Ukai, kakeai sections are between the shite and waki characters. In Yamanba, Zeami is experimenting with a new playwriting approach. The reason for this irregular assignment is because the tsure actor plays an important role to support the shite character's dance. On stage, they do not perform the kuse dance together. However, the tsure is important in the plot because she is famous for her performance of "The Mountain Hag's Kusemai." For the plot, it is crucial to have the interaction between a real mountain hag and a human actor known for her performance of the mountain hag's dance. Waki characters in Zeami's plays have a very specific function of listening to the shite characters. However, Zeami seems to be very flexible about which kind of actors (kyōgen, tsure) to assign to other characters in his plays.

In Nue, Zeami used similar techniques he used in Yamanba. In the mondō section, the monk talks with a villager, played by the kyoggen actor. Then, because villagers refuse to offer the accommodation at their homes for travelers due to local regulations, the monk 
decides to stay in a haunted temple building. In a kakeai section, the monk and the boatman engage in a dialogue. In this section, the boatman tells the monk his identity as the nue monster, who was killed by Minamoto no Yorimasa. This dialogue is followed by a sequence of kuri, sashi, and kuse shödan sub-sections. In this kuse sub-section, the boatman dances while the chorus takes over the boatman's singing to depict how the nue monster was slain. This kuse dance concludes the first act.

Table 2. Dan Sections in Nue

\begin{tabular}{|l|l|l|}
\hline Dan & Events & Major shōdan \\
\hline 1 & The traveling monk enters the stage and travels & \\
\hline 2 & The traveling monk and a villager engage in dialogue & Mondō dialogue \\
\hline 3 & The boatman enters the stage & \\
\hline 4 & The boatman and the traveling monk & Kakeai shared monologue \\
\hline 5 & The boatman tells a story about the nue monster's death & Mondō dialogue, kuri, sashi, kuse \\
\hline 6 & The boatman leaves the stage & Rongi sung dialogue \\
\hline- & Ai-kyōgen: a villager tells a story about the nue monster & \\
\hline 7 & The traveling monk waits & \\
\hline 8 & The ghost of the nue monster enters the stage & \\
\hline 9 & Finale & $\begin{array}{l}\text { Kakeai shared monologue, } \text { kuri, sashi, } \\
\text { songs and dance in chünori rhythm }\end{array}$ \\
\hline
\end{tabular}

Source: Yokomichi and Omote, Yōkyokushū Jō, pp. 303-310.

A new small section used in Nue is the rongi section after the kuse dance. Here, the boatman and the traveling monk take turns singing as if they are talking in a dialogue. However, the traveling monk's lines are sung by the chorus. Rongi sections are a sung version of mondo, where either the shite actor and the chorus, or two actors sing in a dialogue of questions and answers. Rongi sections often come in a set sequence of kuri, 
sashi, kuse, rongi, and nakairi (中入, going off stage). This is what takes place in Nuethe boatman exits after his dialogue, rongi.

In the second act, the main dance section comes at the end of the whole play. This section comes after kakeai, kuri, and sashi sub-sections. Although this section is not a kuse sub-section, the shite actor dances in accordance with rhythmically scored music and the chorus' singing. This section's rhythm is called chünori. In this rhythm, most of the time, sixteen syllables are sung in eight beat measures. Noh playwrights used this rhythm for the ending scenes when a warrior ghost dances and sings while describing suffering in hell, or when a demon dances and sings. The nue monster dances while the chorus sings. The lyrics tell of his suffering in hell after getting killed and thrown away in an empty boat.

Ukai is an example of a Zeami demon play from his early career. Here, we can still see older sarugaku traditions in the play's structure. The most apparent feature is that the play does not have maigoto as its climax. Considering that Zeami integrated maigoto, or originally tennyomai, into most of his surviving plays, this play is a great example of his early work. There are three mondō sections, one kakeai section, and one rongi section. This shows that Zeami emphasized Yamato sarugaku's tradition of enjoyable plots and dramatic dialogues and actings when he wrote this play. Here are the sections (dan) along with major sub-sections (shōdan) in the play Ukai.

Table 3. Dan Sections in Ukai

\begin{tabular}{|l|l|l|}
\hline Dan & Events & Major shódan \\
\hline 1 & $\begin{array}{l}\text { The traveling monk and the accompanying monk enter } \\
\text { the stage }\end{array}$ & \\
\hline 2 & The traveling monk and a villager engage in dialogue & Mondo dialogue \\
\hline
\end{tabular}




\begin{tabular}{|c|c|c|}
\hline 3 & The cormorant fisherman enters the stage & \\
\hline 4 & $\begin{array}{l}\text { The cormorant fisherman and the traveling monk } \\
\text { engage in dialogue }\end{array}$ & Mondō dialogue \\
\hline 5 & $\begin{array}{l}\text { The cormorant fisherman tells a story about his death } \\
\text { and reenacts the cormorant fishing }\end{array}$ & $\begin{array}{l}\text { Mondō dialogue, kakeai shared } \\
\text { monologue }\end{array}$ \\
\hline 6 & The cormorant fisherman leaves the stage & \\
\hline- & $\begin{array}{l}\text { Ai-kyogen: a villager tells a story about the cormorant } \\
\text { fisherman }\end{array}$ & \\
\hline 7 & The traveling monk waits & \\
\hline 8 & The King of Hell enters the stage & \\
\hline 9 & $\begin{array}{l}\text { The King of Hell and the traveling monk engage in } \\
\text { dialogue }\end{array}$ & Rongi sung dialogue \\
\hline 10 & Finale & $\begin{array}{l}\text { Kiri concluding dance with song and } \\
\text { music }\end{array}$ \\
\hline
\end{tabular}

Source: Yokomichi and Omote, Yōkyokushū Jō, pp. 174-180.

In the rongi section in the second act, the King of Hell answers questions from the monk about the Lotus Sutra. A kiri キリ dance section follows this rongi section. Kiri dance is a powerful dance which concludes the play. These kiri dances are usually danced by the actors who play role of demons. Kiri dances are accompanied by the chorus, singing a text. In the kiri dance section of Ukai, the King of Hell says that for sinners, merely hosting traveling Buddhist monks with compassion can lead to salvation.

Kan'ami's approach had a great impact on how Zeami wrote demon plays, as we can see in the example of Ukai. Zeami had not yet established his own approach to crafting plays early in his career. However, in Yamanba and Nue, we can see Zeami's fully established approach to creating demon plays. Zeami's new demon plays included maigoto dance, essential for Zeami to prevail in competition with Inuō to secure the Shōgun's patronage. 


\section{Structure in Nobumitsu's Plays}

Living two generations later, Nobumitsu knew Zeami's plays well. According to Matsuoka, Nobumitsu attempted to surpass Zeami's plays. ${ }^{120}$ His demon plays are characterized by the use of violent battle as the climax, different assignment of actors' roles, and careful inclusion of ai-kyōgen to facilitate the progress of the plot. As we saw when we examined the structures of three demon plays in this thesis, Nobumitsu was innovative in crafting the structures of these plays. Unlike mugen noh structure established by Zeami, two of his plays, Rashōmon and Orochi, do not have the same shite characters in two acts. Rashōmon does not even have a shite character in the first act.

Momijigari is an example in which we can see how Nobumitsu integrated his techniques and dance sections into his plays. Nobumitsu consistently placed kuse subsection at the end of the first act, and utilized maibataraki combat dance as the climax of plays. Maibataraki is a dance form combining maigoto and hatarakigoto, which have both abstract dance movements and sections depicting characters' emotion or actions. In Momijigari, the maibataraki section depicts the combat between Koremochi and the demon in the mountains. Here are dan with the sub-sections in the play Momijigari.

Table 4. Dan Sections in Momijigari

\begin{tabular}{|l|l|l|}
\hline Dan & Events & Major shödan \\
\hline 1 & The noblewoman and her maids enter the stage & \\
\hline 2 & $\begin{array}{l}\text { Koremochi, his retainer, and a hunting assistant enter } \\
\text { the stage }\end{array}$ & \\
\hline 3 & Koremochi, his retainer, and a maid engage in dialogue & Mondo dialogue \\
\hline 4 & The noblewoman and Koremochi engage in dialogue & Kakeai shared monologue \\
\hline 5 & The noblewoman's dances & Kuri, sashi, kuse \\
\hline
\end{tabular}

\footnotetext{
${ }^{120}$ Matsuoka, Nō: Chūsei kara no Hibiki, pp. 66-67.
} 


\begin{tabular}{|c|c|c|}
\hline 6 & The noblewoman dances & Iguse, jonomai dance, kyūnomai dance \\
\hline 7 & The noblewoman leaves the stage & Rhythmic singing, sung poetry \\
\hline- & Ai-kyōgen: a deity appears in Koremochi's dream & \\
\hline 8 & Koremochi waits & \\
\hline 9 & $\begin{array}{l}\text { The female demon enters the stage, followed by } \\
\text { combat }\end{array}$ & $\begin{array}{l}\text { Rhythmic singing, maibataraki dance } \\
\text { with song and music, rhythmic singing }\end{array}$ \\
\hline
\end{tabular}

Source: Yokomichi and Omote, Yōkyokushū Ge, pp. 143-149.

There are three main dances in Momijigarii. Nobumitsu placed a kuse dance in the first act. An iguse without dance follows the kuse dance section. The climax is maibataraki, a battle between the demon and the waki character, Koremochi. In variant stagings, several subordinate demons (tsure) accompany the shite.

In the kuse sub-section in the first act, Nobumitsu utilized this long dance to characterize the demon while she is disguised as a human. Demons dance and sing in these sections. They sing and dance in order to trick humans. This disguise of demons as humans only happens in Momijigari. In Rashomon, the demon and even the shite actor never appear on stage in the first act. In Orochi, the shite actor plays an unrelated role in the two acts. Despite these major differences in the first part of Nobumitsu's three plays, the second half of each play consists only of the battle between demons and waki characters. Zeami did not write any of his demon plays with a battle in the end. Nobumitsu uses kuse sub-sections but in addition, he uses maigoto as a climax. Nobumitsu's maibataraki sections use the taiko drum, which brings more energy to the music and dance. Nobumitsu consciously breaks conventions set by Zeami. He felt free to improvise in playwriting whenever necessary to create the compelling drama that builds up to his climax - an energetic dance in which demons and war heroes fight. 
Rashōmon has an unusual structure for a noh play. Most remarkable is that the play does not have any shite character in the first act. ${ }^{121}$ There are few other plays in the currently performed repertoire that are like this—one is Kayoi Komachi. In Rashōmon, the shite actor only appears in the second act as the demon at the gate. The shite never speaks or sings, but the fight is staged as an exciting dance, together with the waki character Watanabe no Tsuna. The central character who advances the plot is the waki character, Tsuna.

Table 5. Dan Sections in Rashomon

\begin{tabular}{|c|c|c|}
\hline Dan & Events & Major shōdan \\
\hline 1 & Raikō, Yasumasa, Tsuna enter the stage & \\
\hline 2 & $\begin{array}{l}\text { Introduction and descriptive remarks by Raikō and } \\
\text { Tsuna }\end{array}$ & Mondō dialogue, iguse \\
\hline 3 & Yasumasa and Tsuna engage in dialogue & Mondō dialogue \\
\hline- & $\begin{array}{l}\text { Ai-kyōgen: Tsuna's retainer explains how Tsuna decided } \\
\text { to go to the Rashōmon on his own }\end{array}$ & \\
\hline 4 & Tsuna enters the stage & $\begin{array}{l}\text { Kuri, noriji song and music with } \\
\text { onori rhythm }\end{array}$ \\
\hline 5 & Tsuna and the demon engage in combat & $\begin{array}{l}\text { Noriji song and music with ōnori } \\
\text { rhythm, maibataraki dance with song } \\
\text { and music, noriji song and music } \\
\text { with onori rhythm }\end{array}$ \\
\hline
\end{tabular}

Source: Yokomichi and Omote, Yōkyokushū Ge, pp. 162-167.

In the first act, the high-ranking general Minamoto no Raikō played by a waki-tsure actor sings solo during the sub-sections: mondō and iguse. Raikō appears with his four retainers, including the waki Watanabe no Tsuna, and a courtier Yasumasa, Raikō holds forth at a banquet during the night and encourages others to share interesting stories. In

121 There were old manuscripts which had an old lady as the shite in the first act. However, there is no text found until today. See Yokomichi and Omote, Yōkyokushū Ge, p. 162. 
the second mondō section, when another waki-tsure character, Yasumasa, brings up the rumor of the demon at the Rashōmon gate, Yasumasa and the waki character Tsuna get into an argument. Their dialogue establishes the reason for Tsuna to go alone to the gate. At this point, the stage assistant brings the Rashōmon gate property onto the stage. After waki character Tsuna arrives at the gate, the chorus starts singing in onori rhythm. Then, the shite's demon appears on stage and the demon and the waki character Tsuna start fighting with each other. In the maibataraki section, they fight in a spectacular battle accompanied by intense instrumental music, without any singing. The chorus starts singing again after the maibataraki, and the play concludes with Tsuna killing the demon.

Scholars consider Orochi to be one of the earliest noh plays Nobumitsu wrote.

Performance records indicate that Nobumitsu wrote this play in the early stage of career. ${ }^{122}$ We see that he was already using a similar structure in this play as he would use in his later plays.

Table 6. Dan Sections in Orochi

\begin{tabular}{|l|l|l|}
\hline Dan & Events & Major shödan \\
\hline 1 & Susanoo no Mikoto and his retainer enter the stage & \\
\hline 3 & Tenazuchi and Ashinazuchi enter the stage & \\
\hline 4 & Susanoo and Tenazuchi engage in dialogue & Kakeai shared monologue \\
\hline 5 & Susanoo leaves the stage & Kuri, sashi, iguse \\
\hline- & $\begin{array}{l}\text { Ai-kyōgen: a tree spirit reintroduces Susanoo and the } \\
\text { great serpent }\end{array}$ & Rongi sung dialogue \\
\hline 6 & $\begin{array}{l}\text { Susanoo enters the stage and waits } \\
\text { Nhythm }\end{array}$ \\
\hline
\end{tabular}

\footnotetext{
${ }^{122}$ Eguchi, p. 11, and Lim, pp. 31-32.
} 


\begin{tabular}{|l|l|l|}
\hline 7 & $\begin{array}{l}\text { The great serpent enters the stage and Susanoo and the } \\
\text { great serpent engage in combat }\end{array}$ & $\begin{array}{l}\text { Noriji song and music with onori } \\
\text { rhythm, kirikumi dance with song and } \\
\text { music }\end{array}$ \\
\hline
\end{tabular}

Source: Eguchi, “Kanze Nobumitsu no Sakunō Katsudō,”p. 11.

In the kakeai section in the first act, The waki character, the god Susanoo no Mikoto, greets the shite character Tenazuchi, an elderly male deity. After this kakeai, there is a combination of kuri, sashi, iguse, and rongi sections. In these sections, Nobumitsu establishes the reason for Susanoo to slay the giant serpent Yamata no Orochi. After the waki character Susanoo completes preparing a trap for the great serpent, the chorus starts singing in onori rhythm. Then, the shite's giant serpent appears on stage and the serpent and the waki character Susanoo engage in a battle. In the kirikumi section, they fight in a spectacular battle with intense chorus singing and instrumental music. Kirikumi is a shōdan that features combat dance by two actors accompanied by instrumental music and dynamic chorus singing that describes the action. The chorus begins singing again after the kirikumi section, and the play concludes with Susanoo killing the serpent and finding the divine sword Murakumo in the serpent's tail.

As examined above, Nobumitsu consistently had a very similar structure for all the three plays. The climax of the plays are always an energetic battle between the demon played by the shite and the waki character. However, Nobumitsu assigned a variety of actors to important dance and singing sections in the first act. Zeami always assigned these important dances to the shite actors. Prior to Zeami and among other acting troupes, the same actor might play both waki and shite roles. Zeami began to establish the strong distinction between two types of roles and after his time, two troupes became entirely distinct. Only waki troupe actors played waki roles, and only shite troupe actors played 
shite roles. The Kanze school is a school of shite actors. Although Nobumitsu was the manager of the Kanze school, he considered the waki to be equally important as the shite in his plays. Nobumitsu's playwriting approach was very different from Zeami's shite centered plays. Zeami wrote his plays in this way and consistently insisted on the importance of the shite in his noh treatises.

\section{Ai-kyōgen in Zeami’s Plays}

Noh plays with two acts usually position the ai-kyogen between the acts. The most important function of ai-kyōgen is to provide time for shite actor to change costume for the second act. Because the shite characters appear at first in disguise, the actor needs to change his entire costume and mask for the character to appear in his true form in the second act. For demon plays, they usually change from a human outfit to a demon outfit. It takes a long time to change even with other actors helping them.

In ai-kyōgen, kyōgen actors also provide a narrative to help audiences understand the play. These kyoggen characters are usually somewhat lowly persons who speak in a premodern colloquial language unlike in the main acts, which use strictly classical language from the medieval period. Ai-kyōgen narration plays an important role to make it easier to understand the plot of the play because the main acts are difficult to understand for most of the audience. Ai-kyōgen texts were modified through the end of the Edo period, unlike the main texts in play scripts. They are mainly performed by kyōgen actors, with waki characters occasionally taking part in the dialogue. Because these kyoggen actor's schools did not have fixed texts, they kept adjusting the text probably to make it easier for audiences to understand. It is difficult to know exactly what 
Zeami and Nobumitsu had in mind for ai-kyōgen when they wrote their plays. However, we can use the current texts in order to obtain a general sense of what was performed when the plays were written. For analysis, I use the ai-kyōgen texts written in Sanari's Yōkyoku Taikan. This is a transcription from the old text of the Ōkura school (大蔵流), which is assumed to have been transcribed around the Kansei era (寛政, 1789-1801). ${ }^{123}$ In Zeami's plays, different ai-kyōgen can have different functions. One is a comical dialogue during the interval between the two acts $(b a)$. It provides explanation for the narrative and also allows audiences to relax. The other function is to provide a retelling of the whole story in plain language in order to make the whole plot easier for audiences to understand.

In Yamanba, the ai-kyōgen section is after the village woman departs, saying she will come back in her real form. During the ai-kyōgen, the waki, a traveling servant, and the kyōgen actor, a village man, engage in a dialogue about the origins of the mountain hag. The traveling servant initiates the dialogue by asking the local man about the hag. However, the village man does not know anything accurate about the origins of the mountain hags. His fallacious surmises are apparently meant to be comical. He explains that a waniguchi (iron drum in a shrine), a tokoro (mountain potato), or a wooden door can become a mountain hag. The waniguchi drum has a large mouth. The tokoro potato has a long beard. Wooden door is kido 木戸 in Japanese, which sounds like kijo 鬼女， demonic woman. Some of his explanations seem to reflect the belief in tsukumo gami 付 喪神: lifeless objects becoming demons. The waki character rejects all of these

\footnotetext{
123 Sanari, p. 8.
} 
explanations because of how nonsensical they seem. The local man's words parody common beliefs in tukumo gami and also include wordplay. This ai-kyōgen does not provide anything significant for the plot. It demonstrates one function of ai-kyōgen as a comical interlude between the two acts.

Ai-kyōgen sections both in Nue and Ukai are written to summarize the first act in a plain language and to foreshadow what is coming in the next act. Both of the ai-kyogen sections start and end in a very similar manner. In both of these ai-kyogen sections, the kyōgen character visits the temple building, where the traveling monk is staying. The kyōgen character apologizes for not letting the monk stay at his home because of regulations. The monk says that he encountered a strange ghost and asks who this ghost is. In Nue, the kyoggen character tells the legend of how the dead nue monster arrived at this place in an empty boat. The place is Ashiya village in the main text. The kyogen character asks the monk to pacify the soul of the nue monster. In Ukai, the kyogen character tells the legend of cormorant fisherman's ghost and asks the priest to pray for the salvation of his soul. The kyōgen character agrees to cooperate in the service by preparing stones wrapped with transcribed Buddhist sutra in order to sink them in the river to pacify the soul of cormorant fisherman. Although the legends told by kyogen characters are different in details, the function of $a i$-kyōgen is identical. It provides a narrative that summarizes the legend in plain language and creates a reason for monks to pray for the salvation of the soul of ghosts.

Zeami used ai-kyōgen sections to make the story easier to understand. Zeami’s aikyōgen include dialogue between the kyōgen actor and the waki actor. This dialogue may derive from the traditional form of mimicry in Yamato sarugaku tradition. Before 
Kan'ami began writing plays, expressive dialogue, acting, and plot were characteristics of Yamato sarugaku's tradition. These dialogues in plain language surely made plays easier to understand. Combined with rhythmic singing and dance, these straightforward $a i$ kyōgen interludes added to the variety of scenes, preventing plays from being monotonous for audiences.

\section{Ai-kyōgen in Nobumitsu's Plays}

In Nobumitsu's plays, the ai-kyōgen section is performed only by the kyōgen actor. The kyōgen character, usually a local villager, provides a narrative to advance the plot from the first act to the second act by explaining the situation. The kyoggen character in Momijigari is a little different. In this play, the ai-kyōgen is a more important part of the plot. The kyoggen actor performs alone in the ai-kyōgen section, and the actor plays the role of a servant deity of Hachiman god. After Taira no Koremochi gets drunk and falls asleep, this deity appears to wake up Koremochi. This deity is following an order from Hachiman deity to support Koremochi by telling him that the noble lady is really a demon. The deity also brings a divine sword from Hachiman god for Koremochi.

\section{A deity:}

The woman who appeared before you earlier this evening was not a human. She is a demon who lives in this mountain. She intends to trick you and kill you.[...] Because my master gives you this divine sword.[...] Wake up, right now. ${ }^{124}$ 最前のの女は人間にてはなし。この山に住む鬼神なるが。御身を註かし命

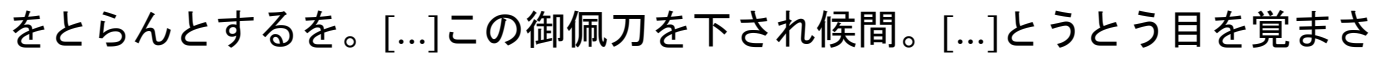
れ候へ候へ ${ }^{125}$

\footnotetext{
124 Translation by Laurence Kominz.

125 Sanari, p. 3089.
} 
Without this $a i-k y \overline{o g e n}$ section, there is no reason for Koremochi to wake up all of sudden and to find a divine sword near him. In the second act, Koremochi wakes up, and says:

Koremochi:

Oh, what a fool I have been. I have drunk the sake of delusion. While I was asleep, I had a miraculous dream. ${ }^{126}$

あら淺ましやわれながら。無明の酒の酔ひ心。まどろむ隙もなきうちに。 あらたなりける夢の告と。127

Here, Koremochi speaks about a revelation in his dream by a deity (yume no tsuge 夢の

告). And, Koremochi picks up the divine sword after he wakes up. This ai-kyōgen deity character and his actions are in Nobumitsu's original play, and prove that he considered this ai-kyōgen essential to his play. This ai-kyōgen section in Momijigari is a very important part of the plot in the main story.

In Rashōmon, the kyōgen actor plays Tsuna's retainer. He explains what happened in the first act and that his master Tsuna is about to investigate the gate to see if there is a demon dwelling there. This retainer fills in some details which are left out of the main text. He speaks for his master Tsuna, saying that Tsuna does not have any personal rancor against Fujiwara no Yasumasa even though Tsuna argued with him. Tsuna is investigating the gate for the emperor. Also, the retainer speaks with another retainer and confirms that Tsuna told them that there is no need to accompany Tsuna. This ai-kyogen section explicitly explains why Tsuna ended up going to examine the Rashōmon gate all alone. Nobumitsu provided a plausible reason to help the audience understand Tsuna's unusual behavior.

\footnotetext{
126 Translation by Laurence Kominz.

127 Sanari, p. 3090.
} 
In Orochi, the kyōgen actor plays a tree spirit in Izumo Province. This spirit explains what happened in the first half and what Susanoo's plan is to slay the giant serpent. In straightforward language, this spirit retells the whole story and prepares the audience for what is coming up next. Unlike Momijigari and Rashōmon, this spirit is an independent character who is not a supporter of either Susanoo or the giant serpent. The spirit comes in as a spectator and depicts what is happening in plain language. The spirit also does not do anything to support either party. Unlike kyōgen actors' villagers in Zeami's plays, this spirit has a unique identity as a tree spirit of Kando ga Dake mountain in Izumo Province. However, this spirit's function in the plot is very similar to Zeami's villagers. Nobumitsu used this character to buy time for costume changing. The difference between villagers in Zeami's plays and this tree spirit is that this spirit speaks in a monologue while Zeami's villagers engage in dialogues with waki characters.

The biggest difference between the use of ai-kyōgen in Zeami's and Nobumitsu's plays is whether they are dialogues or monologues. In these three plays, Nobumitsu made the role of the kyōgen actor simpler and more distinct from the rest of the play. Nobumitsu's kyoggen actors have clear identities and the deity in Momijigari has a very important specific role in the plot. Although overall function is quite similar between the use of ai-kyōgen by Zeami and Nobumitsu, Nobumitsu attempted to change how aikyōgen are used in relation to the main text as we can see in Momijigari.

\section{Zeami's Characterization}

As we see from examining the plays in this thesis, Zeami and Nobumitsu used similar literary sources as raw material for their plays. However, they dramatized source 
stories in different ways in their noh plays. Their use of source stories is therefore quite different. The refashioning of the source stories shows a lot about how each author utilized source stories for writing plays.

In Ukai, Zeami depicts a demon who is not harmful to living humans. The King of Hell is powerful but in this play, he praises the power of the Lotus Sutra and does not harm anyone. The other two demons are violent in pre-existing literary sources. Nue attacked humans in The Tale of the Heike and mountain hags attempted to eat humans in old folk tales. In Yamanba, Zeami refers to a demon's story in Ise Monogatari. Although this story is not the primary original source for the play Yamanba, Zeami cites this story in the line by the courtesan (tsure). The courtesan was in great fear of the mountain hag because she knew a demon could eat humans as described in the tale in Ise Monogatari. Actually, this episode is not about a demon at all. It is about a man who tried to kidnap a beautiful young lady and failed to do so because the young lady was saved by the imperial retainers. The man called those who saved the young lady "demons," who "devoured her in the darkness." Zeami probably cited this tale because of its poetic beauty and its fine waka poetry. In sources prior to Zeami's time, there are two stories: one about a mountain hag-like woman and another about a non-human creature. These stories are in Konjaku Monogatarishū, which was compiled in the Heian period. One is a story about an old lady who attempted to eat her own child while he was hunting in the mountain. ${ }^{128}$ Another is about a female demon who attempts to devour a public servant who comes across her in the mountains. ${ }^{129}$ These are a very violent old lady and a demon,

\footnotetext{
${ }^{128}$ Mabuchi et al, Konjaku Monogatarishü IV, pp. 75-78.

${ }^{129}$ Mabuchi et al, Konjaku Monogatarishū I, pp. 227-231.
} 
which sound like mountain hags, although they are called demon (oni) or rakshasa (rasetsu) in the stories. Later in history, a mountain hag was depicted as the nurturing young mother of Kintarō, a boy of great strength. But, this maternal image is associated with the mountain hags in the Edo period. Zeami seems to have been one of the earliest authors who characterized the mountain hag as having human qualities. I will focus on Yamanba to examine an example of Zeami's characterization of demons.

Zeami depicted the mountain hag very differently from the stories in Konjaku Monogatarish $\bar{u}$. He depicted the mountain hag possessing a duality between the demonic and the virtuous. She is a being who seeks salvation and enlightenment through the Buddhist law. In Yamanba, the mountain hag has the heart to appreciate natural beauty. In the sashi and kuri sub-sections right after she appears in demon form, she describes the beautiful and dreadful landscape of the mountain and valley surrounding her. She wanders around in nature seeking flowers on tree branches in spring, crispy clear moonlight in autumn, and sporadic rain changing into snow in winter. She also helps humans by escorting a tired lumberjack to a village in the moonlight, and by helping a weaver woman to make fabric. But, the mountain hag's appearance has demonic features. Her hair is like thorns and its color is pure white like snow. Her eyes shine sharply like stars. Her face is red (vermilion) and looks like a demon ridge-end tile (onigawara 鬼瓦) painted in red (vermilion). She is also very strong and has supernatural powers as well. She can take any form to appear before humans, and she states that she is taking the form of a mountain hag now. She can move extremely fast to the top of the mountain down into the valley. Thus, for Zeami, the mountain hag was a powerful being, who loves natural beauty and who seeks to speak with humans. 
Unlike the demons in Nobumitsu's plays, the mountain hag in Yamanba engages in a long dialogue with the courtesan, and speaks in monologue as well. In the latter half of the first act, she talks with the courtesan. Even after she appears again in her demon form, she speaks shared lines with the courtesan. After she starts dancing "The Mountain Hag's Kusemai," she takes over the whole conversation. Like Zeami's other demons in Nue and Ukai, the mountain hag speaks in long dialogues and monologues in human language.

This duality of demonic and human qualities are largely inspired by the tenets of Zen Buddhism. For Zeami, the mountain hag is the embodiment of the duality of earthly desires and enlightenment (bonnō soku bodai 煩悩即菩提). Although the hag embodies this duality, she advocates Zen non-duality. Throughout the play, the mountain hag states that good and evil are the same and both can provide a path to attain enlightenment (jasei ichinyo 邪正一如, zenaku funi 善悪不二). She also can take any kind of shape, benevolent or fierce, appearing either good or evil. This characteristic is inspired by the tenet of shiki soku ze kū 色即是空. In Zen's tradition, this tenet means that all things are temporarily in their shape but their essence is emptiness. Thus, all things, both evil and good, can attain enlightenment. Thus, for Zeami, demons are not only evil, but also have the potential to attain enlightenment just as humans have.

In the play, the mountain hag quotes literary sources that describe the beauty and dangerous power of nature. Zeami frequently used allusion to pre-existing poetry (honkadori, 本歌取り). This technique of allusion borrows the world of the pre-existing literature, including their famous physical settings, season, travel, and romance. Zeami 
used these poetic associations to create compelling characters and settings in his plays. ${ }^{130}$ His other purpose was to please his educated audience which enjoyed recognizing familiar poems. Here in Yamanba, the mountain hag continuously describes nature as having the duality of dreadfulness and beauty. Although she never calls herself beautiful, she also states all things show the truth of Buddhist law in their shape as they are. This is especially true for her because she can take any shape. In the second act, the mountain hag states that those who are poor in spirit cannot see the virtue in the mountain hag and call her an invisible demon no matter what good deeds the mountain hag does to help humans. Thus, the dreadful landscapes in the play are objects on which the mountain hag projects her understanding of the truth of Buddhist law. These landscapes are crucial for her as she spends days and nights in the mountains. She is a part of the dreadful nature. When she describes a wide waterfall and a rocky cliff, she quotes and sings a poem from Wakan Rōeish $\bar{u}$ 和漢朗詠集. Noh playwrights including Zeami often quote Wakan Rōeish $\bar{u}$ because audiences were familiar with this anthology. It was often used as a textbook of Japanese and Chinese poetry.

(Zeami's text)

In this world, a myriad entities appear before the eyes:

rushing rivers descending far, craggy peaks soaring high.

Mountains beyond mountains, whose skill sculpted those azure cliffs? Waters beyond waters, in whose house were their jade colors dyed? ${ }^{131}$

万箇目前の境界。懸河渺々として。巌峨々たり。山また山。いづれの匠 か。青嚴の形を。削りなせる。水また水。誰が家にか碧潭の色を。染め出 せる $^{132}$

\footnotetext{
${ }^{130}$ Goff, pp. 36-37.

${ }^{131}$ Brazell and Araki, p. 217.

132 Sanari, p. 3177.
} 
(Original poem)

Mountains beyond mountains,

whose skill sculpted those azure cliffs?

Waters beyond waters,

in whose house were their jade colors dyed? ${ }^{133}$

山また山 何いづれの工か靑嚴の形を削り成せる 水また水 誰が家にか碧澗 の色を染め出いだせる ${ }^{134}$

This is a direct quotation unmodified from the original source. This poem is under the theme of mountains and waters (sansui 山水). The same kind of awe at the beauty, wonder and dreadfulness of the landscape is expressed in the poem as the mountain hag expresses when she describes the landscape before her. Similarly, Zeami quotes a whole Chinese poem from Wakan Rōeish $\bar{u}$ in the kusemai dance section by the mountain hag. Because there is no flogging of sinners and no drums are needed to remonstrate rulers, fireflies fly out of decaying whips and birds are never surprised by the sound of drums. Here, again the mountain hag describes a peaceful landscape in a poetic fashion. This poetry adds lyric beauty to the dreadful landscape of which the mountain hag is a part.

Zeami also quotes almost entire verses from Kokinshī.

(Zeami's text)

Surrounded by trees near and far, unsure of directions deep in the mountains, faint and forlorn, a small bird cries out how unearthly a sound the ringing of a woodsman's ax only makes the mountain stillness greater.

Sacred peaks soaring. ${ }^{135}$

遠近の、たづきも知らぬ山中に、おぼつかなくも呼子鳥の、声すごき折々 に、伐木丁々として、山さらに幽かなり136

\footnotetext{
${ }^{133}$ Borrowed from the translation in Brazell and Araki, p. 217.

${ }^{134}$ This poem is by Ōe no Sumiakira, poem 1013 in Wakan Rōeishü. Cited in Sanari, p. 3180.

${ }_{135}$ Brazell and Araki, p. 221.

${ }^{136}$ Sanari, p. 3180.
} 
(Original poetry)

Surrounded by trees near and far, unsure of directions deep in the mountains, faint and forlorn, it is a small bird. ${ }^{137}$

遠近のたづきも知らぬ山中におぼつかなくも呼子鳥かな138

The underlined words are the quoted parts of the verses. This poem is placed in the beginning of the same kusemai section right after the firefly poem. Because it is deep in the mountains, it is silent all around. The subtle sound of a bird is heard occasionally. And, Zeami quotes a part of a Chinese poem to add more mystery and beauty to the mountain (the ringing of a woodsman's ax only makes the mountain stillness greater. Sacred peaks soaring.). Zeami sometimes borrowed classical poems in their entirety when they could help him to develop the kind of scenery he sought to create. In Nue, there is only one instance Zeami quoted a whole poem. Zeami incorporated more classical poetry into Yamanba than in the other two demon plays. Through the technique of allusion, Zeami utilized these poems to characterize his human-like demons with graceful and elegant qualities of yügen.

Almost all the poetry cited appears in the sung sections of noh plays. This principle applies also to poetry quoted in its entirety. The examples examined above are all sung, and often accompanied by dance as well. The poem about mountains and waters is in the kuri sub-section, or soliloquy by the mountain hag when she first appears on stage in demon form. Another Chinese poem and the Japanese poem about a yobikodori bird are in one of the main dance sections - the kuse. Zeami utilized sung poems both to create character and enhance the drama of the play.

\footnotetext{
${ }^{137}$ Borrowed from the translation in Brazell and Araki, p. 221.

138 This poem is poem 29 of Kokinshü. Cited in Sanari, p. 3180.
} 
Zeami also used and modified fragments of poetry that he borrowed from

classical sources. He integrated these lyric fragments into his sung poetry. In the

following introduction section of the kuse sub-section, the mountain hag and the

courtesan engage in a kakeai shared monologue singing together. This kind of kakeai

sections shows hearts and souls understanding, empathizing, merging with each other.

(Borrowed Fragment in Zeami's text)

Mountain hag: a pheasant cries, flapping its wings

Courtesan: drums of cascading waves

Mountain hag: sleeves of shimmering white

Courtesan: swirls of snow from blossoming trees.

Mountain hag: Is there anything

Courtesan: not encompassed in Buddhist Law?

Chorus: good and evil dragging, Yamanba

dragging good and evil, Yamanba

makes her mountain rounds in pain; ${ }^{139}$

Mountain hag: 一声の山鳥羽をたたく

Courtesan: 鼓は滝波

Mountain hag: 袖は白妙

Courtesan: 雪を廻らす木の花の

Mountain hag: なにはのことか

Courtesan: 法ならぬ

Chorus: よし足引の山姥が。よし足引の山姥が山迴り、するぞ苦しき140

(Original poem 1)

A pheasant cries, and it resounds beyond clouds in the dawn.

Ten thousand flickering lights - fireflies from the waters glowing in the autumn grass. $^{141}$

\section{一声山鳥曙雲外、万点水蛍秋草中}

(Original poem 2)

Flowers of spray bloom on Naniwa harbor. After winter seclusion, now spring is here and tree flowers have burst with bloom.

難波津に咲くやこの花ふゆごもりいまをはるべと咲くやこの花 ${ }^{142}$

\footnotetext{
${ }^{139}$ Brazell and Araki, pp. 219-220. The first line of the quote is modified by the author.

140 Sanari, p. 3179.

${ }^{141}$ Additional parts of translation are by the author. This poem is by Xu Hun in Wakan Rōeishü. Cited in Sanari, p. 3179.

${ }^{142}$ Additional parts of translation are by the author. This poem is in Kokinshü. Cited in Sanari, p. 3179.
} 
(Original poem 3)

In Naniwa, the harbor's province, is there anything not encompassed in Buddhist

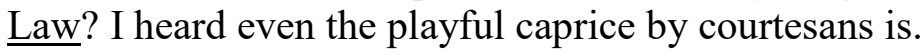
津の国のなにはのことか法ならぬ遊び戯れまでとこそきけ143

This shared monologue is important, sung right before beginning the kuse dance section. Zeami placed this discourse between the mountain hag and the courtesan to create scene where they dance together. In the actual noh play, as it is staged today, only the shite actor (mountain hag) dances. However, this tightly coordinated exchange of sung text illustrates how well they could perform together. Here, Zeami did not quote whole verses of poetry but integrated three pre-existing poems into his own lines. By using keywords from famous poems, Zeami borrowed the scenes from this poetry incorporating it into the singing exchange. In the context of the play, this deft integration of poems in singing shows sophisticated mastery of poetry by both characters.

As examined above, Zeami uses poetry collections such as Wakan Rōeishū and Kokinsh $\bar{u}$. He uses classical and popular sources. Kokinsh $\bar{u}$ was the bible for poets and Wakan Rōeish $\bar{u}$ was used for educational purpose among elite classes, both samurai and aristocrats. My analysis to this point has focused on how Zeami used poetry to create powerful and expressive plays.

As examined above, Zeami used artistic vehicles such as long dialogues and monologues by demons, and citation of Zen Buddhist tenets and classical poetry. Through these techniques, Zeami characterized his demons having refined human qualities. In Heike Monogatari, the nue monster is a powerful creature, which attacks the

\footnotetext{
${ }^{143}$ Additional parts of translation are by the author. This poem is by Yūjo Miyagi (the courtesan Miyagi) in the Goshūishū. Cited in Sanari, p. 3179.
} 
emperor with supernatural power by terrifying and sickening the emperor. In medieval literature, there are many ghosts which can physically harm people as well. So, for both cases, Zeami could have characterized these demons as violent beings, following his source stories. However, he intentionally chose not to do so, and instead made them appear as human-like creatures, with human emotions and sensitivities. These demons have appreciation for natural beauty, and they are well educated in classical poetry just like Zeami himself and his audiences. Demons are powerful supernatural beings, but for Zeami, they were a part of the unified world of humans, demons, and other creatures all living at the same time in the same world.

\section{Nobumitsu's Characterization}

Nobumitsu characterized his demons as evil monsters. Unlike Zeami's demons, when they appear in demon form, they never speak human language except for a very few limited instances. Other characters describe how fearsome these demons appear and behave in the first act setting to stage mortal combat in the second act. However, only Momijigari's demon has long dialogues and monologues in the first act while she is in the form of a human noblewoman. Momijigari's demon attempts to kill Taira no Koremochi by disguising herself as a noble lady to seduce him. The characterization of the demon as a beautiful and educated lady in the first half creates surprise and stark contrast after her identity as a demon is revealed in the second act. Traditionally, demons, foxes, and other supernatural creatures have the ability to change their forms to trick humans. These cunning tactics show the demon's supernatural abilities. The demon in Momijigari appears beautiful in human form, and she has very sophisticated abilities. She 
can quote and sing classical poetry and dance elegantly when she hosts a banquet for Koremochi. Unlike Zeami, Nobumitsu never meant for these abilities to indicate human qualities in his demons. The evidence supporting her true nature as a purely evil nonhuman monster is that the demon never speaks after revealing her true form, and she is killed without saying a word. There is no sympathy for the demon, nor salvation for her soul. Next, I will examine how Nobumitsu characterized this demon in Momijigari. Until the $a i-k y \overline{o g e n}$, there is no mention of an imperial order for Koremochi to slay the demon of Togakushi Mountain. Up to that point, Nobumitsu keeps everything about the identity of the noblewoman secret. Before falling asleep, Koremochi admits that his heart is disturbed by how beautiful the noblewoman is, and how there is no other like her. Scholars speculate that these details about the imperial order and the location of Togakushi mountain were added by somebody other than Nobumitsu. One reason for this speculation is that Koremochi says that his purpose for going into the mountains is to hunt deer. Unless the play was written as a satire or to be a realistic play, it is unlikely that an imperial retainer would go hunting and get drunk with a beautiful stranger if he was on an imperial mission. However, the help from a servant deity of Hachiman god and the sword are crucial parts of the play, and essential for the second act. There is not even a single instance in which the word "demon" appears in the script in the first act. Nobumitsu meant to surprise audience during the ai-kyoggen by revealing the beautiful noblewoman's identify as a demon. For Nobumitsu, the beauty, erudition, and dancing skills of the noblewoman show how cunning the demon is. This demon is fully capable of seducing an educated and brave samurai. 
Before Koremochi appears on stage, the noblewoman and her maids praise beauty of autumn leaves and who goes deeper in the mountains to see these colorful leaves. The noblewoman says that she and her maids are living a humble life in the mountains, and no one ever visits them. In a poetic overstatement, she says that they are living in a shabby house with grass growing abundantly around it, concealing it like clouds. Praising the beauty of autumn leaves, she quotes three classic poems singing them.

(Nobumitsu's text)

The leaves beneath,

Were they painted by the dew

That fell last night,

That fell last night?

Deeper in hue than yesterday

The fresh field spreads at morn.

The more I seek the crimson leaves,

The more I seek the mountain-depths.

The dam the wind has built,

Upon the mountain stream-

$\mathrm{O}$ it is bound with fallen leaves

That linger on the water's course.

If once I cross them, I shall break

The gay brocading on the stream;

Then will we stop beneath the trees

To rest, and contemplate

The glory of the autumn

In the tree-tops all around. ${ }^{144}$

下紅葉。夜の間の露や染めつらん。夜の間の露や染めつらん。あしたの原 は昨日より。色深き紅を分け行く方の山深み。げにや谷川に。風のかけた る柵は。流れもやらぬもみぢ葉を。渡らば錦中絶えんと。まづ木のもとに 立ち寄りて。四方の梢を眺めて暫く休み給へや145

(Original poem 1)

The leaves beneath-Were they painted by the dew that fell last night? The field spreads

at morn deeper in hue than yesterday. ${ }^{146}$

\footnotetext{
${ }^{144}$ Nihon Gakujutsu Shinkōkai, p. 147.

145 Sanari, p. 3081.

${ }^{146}$ Borrowed from the translation in Nihon Gakujutsu Shinkōkai, p. 147.
} 
下紅葉夜の間の露や染めつらん あしたの原のきのふより濃き147

(Original poem 2)

The dam the wind has built, upon the mountain stream-O it is bound with fallen leaves

that linger on the water's course. ${ }^{148}$

山川に風のかけたる柵は流れもあへぬ紅葉なりけり149

(Original poem 3)

In Tatsuta river, a myriad autumn leaves flow all over on the surface of river. If we row a boat, the brocade would be cut in the middle.

龍田川紅葉乱れて流るめり渡らば錦中や絶えなん ${ }^{150}$

Two of them are quoted in close to their entirety. Nobumitsu cites only the latter half of a poem about rowing a boat through a brocade of floating leaves. Borrowing from a classical poem, the noblewoman says she is even afraid to ruin the perfect view of a myriad autumn leaves floating on the surface of river. In accordance with the autumn setting of the noh play, Nobumitsu quotes many poems from literary sources under the theme of autumn. Here, through the allusion to poems known by aristocrats, Nobumitsu created this noblewoman character to match with the persona of high-ranking warrior Taira no Koremochi. This lady is not only beautiful, she also has a very refined education as we see in her mastery of poetry and elegant dance. She also has a gentle heart that loves natural beauty. Nobumitsu borrowed poetry from Shin Kokinshu and fables from Chinese sources to write lines for the chorus and the samurai Koremochi. However, whenever this noblewoman sings poetry, it is from Kokinsh $\bar{u}$, which was the bible of poetry for aristocrats. Nobumitsu chose poems for his characters that match their personality and social class. Kokinshü is older and it was the most popular anthology for

\footnotetext{
147 This poem is in the theme of autumn leaves in the Tsuchimikadoingyoshü. See Umehara et al, p. 431.

${ }^{148}$ Borrowed from the translation in Nihon Gakujutsu Shinkōkai, p. 147.

149 This poem is by Harumichi no Tsuraki in Kokinshū. Cited in Sanari, p. 3179.

${ }^{150}$ The translation is by the author. This poem is by an unknown poet in Kokinshü. Cited in Sanari, p. 3082.
} 
refined aristocrats in the Heian period. Kokinsh $\bar{u}$ poems suit the lady in the noh play. Shin Kokinsh $\bar{u}$ was more popular among warriors a few hundred years later, so these poems suit Taira no Koremochi.

After Koremochi confesses how disturbed his heart is by the noblewoman's beauty, she replies that she too has fallen in love with Koremochi. She says that their meeting was predestined by karma in their past lives. However, this occasion is a fleeting one and she is sad about transient nature of their relationship. She is perplexed and unable to determine what to do. This is a natural human reaction to such occasions. Her hesitation and indecision are understandable. A normal woman would never give herself right away to a man whom she met by chance in the mountains. After this dialogue between the noblewoman and Koremochi, she starts singing and dancing and Koremochi falls asleep because he drank so much sake. Up to this point, the noblewoman is perfectly human without showing any hint of demonic qualities. But when she dances after Koremochi falls asleep, a few hints are provided about her true nature. While she dances, she occasionally checks to see if Koremochi is asleep or not. And, before leaving the stage, the chorus sings that she hopes that Koremochi will never wake up. As mentioned earlier, Nobumitsu crafted a very shrewd and skillful demon who can trick an educated samurai like Koremochi.

In the second act, the demon comes back on stage in demon form. Now the demon has lost all the human qualities she demonstrated in the first act. She does not even speak human language. The demon can breathe fire and she can fly. When the demon appears, there are flames from a thunderbolt right near Koremochi, making a sound which shakes the earth and sky. At this time, Koremochi's retainers leave the stage 
for unknown reasons, probably because they are afraid of the demons. The demon is so fearsome that only an exceptionally brave warrior hero such as Koremochi can face her and fight with her. Nobumitsu created a fascinating demon with two entirely different personas: beguiling noblewoman and horrific demon.

Nobumitsu's other two demons in Rashömon and Orochi are much more straightforward. These two demons appear in demonic form from their first appearance in the second act. In the first act, other characters talk about these demons and describe their fearsome characteristics, such as devouring humans or dwelling at the gate and terrorizing people. However, the demons themselves do not appear in any way in the first act. When they appear in the second act, they are powerful and harmful monsters that attempt to kill the warrior heroes played by the waki. In Orochi, the great serpent fights the waki character Susanoo because Susanoo tries to slay the serpent. However, in Rashömon, the demon attacks waki character Watanabe no Tsuna all of sudden in the darkness without any apparent reason. These two demons do not try to trick humans, but they just attempt to kill humans with their mighty powers. Momijigari's demon is an exception among Nobumitsu's demons because of the cunning trick she can play on an educated samurai warrior. Nobumitsu used the technique of poetic allusion as Zeami did. However, the characterization of demons by these allusions is quite different from Zeami's characterization. Whether they are fearsome violent monsters or a cunning demon, these demons are depicted as evil and have special abilities to harm humans. In his demon plays, Nobumitsu always depicted his demon as powerful and evil antagonists to create a enjoyable conflict. He rarely wrote his plays as mugen noh with dream visions 
to show the demons' inner feelings as Zeami did. ${ }^{151}$ Nobumitsu chose to be more straightforward about the characterization of his demons. Nobumitsu did not change harmful demons to human-like demons. Instead, he put powerful characters on stage, both good and evil, to engage in spectacular battles. This was the foundation of his stage spectacle.

\section{Different Characterization between Zeami and Nobumitsu}

As this chapter shows, it is not source story's genre but its treatment by the playwrights which distinguishes the play crafting of Zeami and Nobumitsu. Their source stories all presented dangerous, and fearful demons. Zeami looked to a variety of demon stories to create his human-like demons. Having sympathetic supporting characters such as traveling monks, he created his original narratives of demons with human qualities. Nobumitsu's characterization of demons is straightforward and closer to his source stories. For Nobumitsu it was more important to build up their evil, dangerous, violent nature and to create an exciting battle for the climax of his plays.

Zeami used kuse dance and maigoto as an important means to depict human-like demons. Zeami's demons recite poetry or scripture and this demonstrates their humanity and erudition, equivalent to an elite education. Zeami created sophisticated dances by human-like demons to end the day's program. Like Zeami, Nobumitsu used kuse but he placed them in the first act of his plays. Nobumitsu created his own approach for

\footnotetext{
${ }^{151}$ Nobumitsu wrote Kochō 胡蝶 and Yugyo Yanagi 遊行柳 in the mugen noh structure. In these plays, the waki priest sees dream-like vision in which the butterfly sprit (Kochō) and the willow tree spirit (Yugyō Yanagi) appear. Both plays are categorized as woman play because these spirits appear in woman form in the first act.
} 
maibataraki, using them for combat. Unlike Zeami's solo dance, these climax dances were always performed by two actors: the shite actor and the waki actor. This created stage spectacle to finish the day's program with much excitement.

Zeami created humanized demons who relate their own stories. The mountain hag speaks and sings about how she suffers in the mountains, and she illustrates her life in the mountains by dancing. The nue monster also tells about his deep suffering and remorse about his deed of attacking the emperor while he was alive. Zeami characterizes these demons as having human qualities and $y \bar{u} g e n$ qualities, appealing to the aesthetics and preference of his audience, composed of people who appreciate gracefulness and harmony. These plays represent the ethos of Zeami's audiences including Ashikaga Yoshimitsu. Nobumitsu created demons with power, violence, and cunning. These demons are powerful antagonists without human qualities and they engage in the spectacular combat on stage. This stage spectacle and the value of reliance on human power assisted by the divine corresponds to the social and cultural values among Nobumitsu's audience in the Sengoku period.

I examined demon plays' scripts by Zeami and Nobumitsu from the different perspectives. In order to understand more about play direction and visual and musical aspects of these plays, I will examine costumes, masks, dance, singing, and music accompaniments in the next chapter. 


\section{Chapter 4: Directions, Music, Dances, and Staging Conventions}

As examined in the previous chapter, Zeami and Nobumitsu characterized their demons very differently, expressing a different ethos in their plays. Zeami emphasized the social core value of inclusion of the Other and created graceful, mysterious, and humanized demons. The purpose of his plays was to pacify their souls. Nobumitsu created the extravagant stage spectacles so that warlords who presented his plays could impress their guests. In Nobumitsu's plays, warrior heroes engage in fierce combat and kill powerful demons. I will analyze how differently Zeami and Nobumitsu used music, performative, and visual elements in their plays in order to depict different kinds of demons and other main characters. Zeami and Nobumitsu used different dramaturgy and techniques to craft their plays: the number of characters in their casts, their different approaches to costume and masks, stage properties, stage sets, choreography, music and song, use of instruments, and rhythm. I will examine all of these aspects of both authors' demon plays in this chapter.

\section{Number of Characters}

Noh drama has simple staging conventions. It does not use theater buildings which allowed later forms of theater to develop large stage spaces and extensive large stage sets. Noh drama does not use artistic electric lighting, and amplified sound effects. There are only a few stage properties used and they are more symbolic than realistic. For example, the stage property of the mountain in Momijigari is slightly larger than the size of an adult human. The stage set has some colorful autumn leaves attached to it. The background on the back wall is always a pine tree. This configuration is enough for $n o h$ 
plays to stimulate audiences' imagination to fill in the details. Except for actors who have assigned roles, all the other chorus members and musicians wear almost identical outfit of a crested black kimono and hakama trousers (紋付袴). ${ }^{152}$ Thus, this configuration leads audiences to focus their attention to actors playing the roles of characters on stage. In this form of theater, the stage presence of main actors matters significantly for audiences. In addition to how well the actors perform, the number of actors in costume, and the masks they wear make a significant difference in dramaturgy.

The number of characters in casts varies according to directions among schools and different productions. Here, I refer Yōkyoku Taikan for the number used in my analysis. Simply by looking at the number of characters on stage, we can begin to distinguish differences in how Zeami and Nobumitsu wrote their plays. Of the three Zeami plays, Yamanba has the largest number-six to seven actors. The number changes because waki-tsure's number varies from two to three. Nue has the smallest number having only three actors. They are the shite, waki, and kyōgen actors. Two characters, a shite and a waki, are the bare bones minimum number of costumed characters in a noh play. Ukai has four actors, having only two actors - a waki-tsure and a kyōgen actor-in addition to the two primary roles of the shite actor and the waki actor. Zeami's other demon play Nomori has four actors as well. Nue and Yamanba were written in his later career, and Zeami likely experimented considerably with Yamanba by using more actors than usual. In his treatise "Sarugaku Dangi," he states that Yamanba sometimes digresses

\footnotetext{
${ }^{152}$ Crested kimono (montsuki, 紋付) has five family crests. There are a crest on both sides of the chest, on both sleeves, and on the back. Chorus, musician, and main actors all wear montsuki of this style. See Yokomichi et al, Nō no Kōzō to Gihō, pp. 147-148.
} 
from the main story. ${ }^{153}$ However, he was very consistent in using a limited number of actors - generally three to four. For his unique structure of mugen noh, probably more actors on stage meant more distraction for the audience, hindering their focus on the shite actor's singing and dances.

Unlike Zeami, Nobumitsu placed a large number of costumed characters on stage. In Momijigari, there are seven to nine, not including many waki-tsure actors, who play retainers of the waki character Taira no Koremochi. Rashōmon has eight actors, with five waki-tsure who play Minamoto no Raikō and other retainers. These samurai warrior heroes engage in discussion and argument with the waki character Tsuna. Orochi has nine actors. Right after it was written by Nobumitsu, there was a direction in which eight actors combine to play the role of the great serpent together. They wanted a festival-like serpent, with many performers. This direction adds up to sixteen actors. They abandoned this direction quickly and no school produces Orochi using this direction now. ${ }^{154}$ Compared with the number of actors Zeami's plays used, Nobumitsu clearly wrote his plays for stage spectacle with beautiful costumes and more movement by many actors.

\section{Costumes and Masks of Demons and Main Characters}

Because the actors are the center of audiences' attention, their costumes and masks matter significantly in dramaturgy for noh plays. In this thesis, I focus on the shite actors' demons and on waki characters to examine how Zeami and Nobumitsu used these important visual aspects of plays. Around the time of Zeami and Nobumitsu, noh

\footnotetext{
153 “Sarugaku Dangi," Zeami Zenchiku, p. 286.

${ }^{154}$ Eguchi, pp. 16-17.
} 
costumes were different from what we see in theater today. Because standardized noh drama costumes were yet to be established, noh performers used normal outfits available on the market. ${ }^{155}$ After the mid-sixteenth century, patrons started donating to produce outfits for their favorite actors. We do not know what kind of costume actors wore when the plays were written. However, today's costumes reflect noh's conventional interpretation of characters. So, we can still examine these to find a good sense of how Zeami and Nobumitsu intended to represent their demon characters.

Compared with costumes, masks are a more reliable source to interpret visual theater in its original form. Although the conventions for masks' forms were not established in Zeami's time, noh actors including Zeami paid great attention to masks and mask makers. ${ }^{156}$ Each noh school and actor's family transmitted their masks from generation to generation. Some of them date back to the late Muromachi period and are still used today. Thus, we can assume that the current use of specific mask type is according to the original playwrights' direction.

The waki actors' male characters such as monks and samurai warrior heroes are much more straightforward than the shite actors' demons. In this chapter, I will examine the costumes and masks of the demon characters both in human form and demon form because these details significantly affect the characterization of the demons.

Costumes and Masks in Zeami's Demon Plays

\footnotetext{
${ }^{155}$ Ishii, p. 209.

${ }^{156}$ Yokomichi et al, Nō no Kōzō to Gihō, p. 199-202.
} 
In Zeami's demon plays, the shite appears in different costumes and masks in each act. The shite actor appears in human form in the first act and disappears from the stage before the ai-kyōgen. The shite actor comes back on stage in demon form in the second act. This changing of appearance and outfit is a crucial part of his playwriting approach. Thus, for Zeami's demon plays, it is important to examine the shite actor's costumes and masks in both acts because they are both parts of Zeami's characterization of demon characters.

In Yamanba, the shite actor first appears on stage as a village woman. The actor wears a middle-aged woman mask (fukai 深井) with a wig. ${ }^{157}$ Female characters always wear wigs, and this wig is simple long black hair. The costumes are a beige (asagi 浅黄) collar, under kimono cloth (kitsuke 着付) with printed foils (surihaku 摺箔), and outer layer (kinagashi 着流) of Chinese weave (karaori 唐織) without red color (ironashii 無 色). ${ }^{158}$ The under-cloth of foil prints is a white short sleeved kimono (kosode 小袖) decorated in a pattern with silver or gold foils. This cloth is used for various female characters. Chinese weave is the kimono which modeled Chinese style cloth. These decorative fabrics have raised patterns using plenty of woof throughout textile, usually with the theme of landscape or objects from nature. The outer layer of Chinese weave is used for female characters in general. ${ }^{159}$ However, this costume of the village woman does not have a red color. In noh drama, red color represents youth in female

\footnotetext{
${ }^{157}$ For an illustration of the mask, see the illustration 7 in Sanari, Yōkyoku Taikan Shukan.

${ }^{158}$ Sanari, p. 3171.

${ }^{159}$ Yokomichi et al, Nō no Kōzō to Gihō, p. 159.
} 
characters. ${ }^{160}$ Costumes without red color are worn by middle-aged women. Here, the village woman wears a beige collar and non-red Chinese weave out layer kimono, with a middle-aged woman mask. By examining the characteristics of her costume, we can see that this character is portrayed as a middle-aged female human.

In the second act, the shite actor appears in demon form. The mask is the mountain hag mask (yamanba 山姥) and two different wigs can be used: a white-haired wig (shiro gashira 白頭) or a mountain hag wig (yamanba kazura 山姥鬘). ${ }^{161}$ The golden eyes of the mountain hag mask show she is a supernatural being. The white-haired wig looks unkempt and represents wild supernatural beings. The mountain hag wig represents a more human-like character than the white-haired wig. The costumes are beige (asagi) collar, under-cloth of plain short sleeve kimono without patterns (muji noshime 無地慰斗目), twill-woven short sleeve kimono (atsuita 厚板) with hems tacked into sash belt (tsuboori 壶折), wide patterned hakama trouser woven with gold foil threads (hangiri 半切), sash belt, and fan. ${ }^{162}$ Muji noshime is used for samurai retainers, male commoners, monks of low ranks, and middle-aged or elderly woman from the countryside. ${ }^{163}$ Atsuita is thickly woven kimono often with Chinese themed patterns such as a hexagonal pattern or mythical lions. This atsuita kimono is often worn as underkimono by male characters, powerful gods (aragami 荒神), monsters. This robe is also worn by elderly women of low rank as an outer kimono. ${ }^{164}$ Hangiri trouser are worn by

\footnotetext{
${ }^{160}$ Yokomichi et al, Nō no Kōzō to Gihō, pp. 144-145.

${ }^{161}$ For illustrations of the mask and costumes, see Figure 6 and 7 in Appendix B.

162 Sanari, p. 3176.

${ }^{163}$ Yokomichi et al, Nō no Kōzō to Gihō, p. 158.

${ }^{164}$ Ishii, p. 215.
} 
powerful characters such as demons or warrior lords. By examining these costumes, we see that the mountain hag has characteristics of an elderly woman in the countryside, a powerful demon, and a male human.

Fans are often used in dances by the shite characters. However, whether characters are major characters or not, noh actors usually hold fans. These fans are held to give dignity to the noh drama, much in the way that aristocrats carried fans as part of their official dress. ${ }^{165}$ Following the protocols of official ritual entertainment, noh actors including waki-tsure hold these fans even when their characters do not use these fans on stage. The mountain hag also holds a long staff (kasetsue 鹿背杖). This staff is used by the mountain hag in Yamanba, elderly dragon god in Tamai, elderly ghosts in Koi no Omoni and Aya no Tsuzumi. ${ }^{166}$ This staff can be a branch of a real tree or thick bamboo wrapped with textile. In Yamanba, the mountain hag holds this stick and uses it in her maigoto section at the end of the play. The mountain hag's mask and wig are very unique and these are used only for this play Yamanba. Character specific masks are quite rare and this shows how different Zeami's mountain hag is from other demons. The unique character of the mountain hag contributed to this play's special position and popularity in noh drama's repertoire. From the Muromachi period onward, this play has been frequently performed. This frequency may have contributed to standardizing costumes and masks for the mountain hag. Even among demon plays, the play Yamanba has a very special position having mixed qualities of an elderly female, a man, and a powerful demon.

\footnotetext{
165 Yokomichi et al, Nō no Kōzō to Gihō, p. 128.

166 Yokomichi et al, Nō no Kōzō to Gihō, p. 123.
} 
In Nue, the shite actor appears as a boatman in a hollow boat in the first act. The actor wears a male ghost mask (mikazuki 三日月) with a black haired wig (kuro gashira 黒頭). ${ }^{167}$ Although this mask has human-like features, its golden eyes show the character is a ghost. The black hair indicates that he is more human than supernatural characters with red hair or white hair. The costumes are a navy blue (kon 紺) collar, a solid color noshime kimono undergarment, an outer layer plain kimono with open sleeves (shike mizugoromo 絓水衣), a sash belt, and a fan. ${ }^{168}$ Mizugoromo is an austere kimono with no pattern. This kimono is worn as outer layer cloth for monks, mountain wizards, supernatural beings disguising themselves as elderly humans, deranged humans, or male commoners. ${ }^{169}$ This shows this character has a commoner-like appearance with just a hint of the supernatural.

In the second act, the shite wears a monster mask (kotobide 小飛出) with a redhaired wig (aka gashira 赤頭). ${ }^{170}$ This monster mask has wide open golden eyes and its tongue is clearly visible. Unlike in the first act, his hair is red and now he is clearly appearing as a demon. The costumes are a navy blue collar, a twill-woven short sleeve kimono with borders (dan atsuita 段厚板), a happi kimono woven with gold foil threads (happi 法被), a wide patterned hakama trouser woven with gold foil threads (hangiri 半 切), a sash belt, and a fan. ${ }^{171}$ Happi is worn by characters such as supernatural beings

\footnotetext{
${ }^{167}$ For an illustration of the mask, see Figure 8 in Appendix B.

168 Sanari, p. 2381.

${ }^{169}$ Yokomichi et al, Nō no Kōzō to Gihō, pp. 142 and 155-156.

${ }^{170}$ For an illustration of the mask, see Figure 9 in Appendix B.

${ }^{171}$ Sanari, p. 2389.
} 
with red hair or black hair wigs except for deities, tengu demons, warrior ghosts, who do not wear happi. ${ }^{172}$ The nue monster has a red-haired wig matching this convention. Among the three Zeami's plays examined in this essay, Zeami made this demon look more like a monster than the other two. Zeami was likely inspired by the monster's bizarre appearance as described in the script. However, considering the nue monster has the face of a monkey and all other body features are from various animals, this appearance still looks much closer to a human being than to its appearance in the text.

In Ukai, the shite actor only appears as the King of Hell in the second act. The actor wears a righteous demon mask (kobeshimi 小癋見) with a red-haired wig (aka gashira 赤頭) and a Chinese hat (tō kamuri 唐冠). ${ }^{173}$ This righteous demon mask represents demons who are not harmful to humans although they are very powerful. The Chinese hat shows a noble rank that the demon holds at where he dwells. These characteristics match what the demon does in the play Ukai. He witnesses the salvation of cormorant fisherman's soul and praises the power of the Lotus Sutra. The costumes are a light blue (hanada 縹) collar, a twill-woven short sleeve kimono underrobe (atsuita), a kariginu cloak outer garment (hunting cloak, kariginu 狩衣), wide patterned hakama trousers woven with gold foil threads (hangiri), a sash belt, and a fan. ${ }^{174}$ The name kariginu derives from the hunting cloaks of aristocrats in the Heian period. This was aristocrats' casual private outer kimono at that time. By the Muromachi period, kariginu became the official outfit for the upper warrior class. ${ }^{175}$ In noh plays, actors wear

\footnotetext{
172 Yokomichi et al, Nō no Kōzō to Gihō, pp. 154-155.

${ }^{173}$ For illustrations of the mask and costumes, see Figure 10 and 11 in Appendix B.

${ }^{174}$ Sanari, p. 309.

${ }^{175}$ Yokomichi et al, Nō no Kōzō to Gihō, pp. 154-155.
} 
kariginu woven with gold foil threads. Characters wearing kariginu are among the most respected characters in noh plays including deities, aristocrats, upper echelon warrior lords. Considering noh drama's main patrons were of the samurai class, this righteous demon has a similar status to upper-class warrior lords. Hangiri trousers are used for powerful characters and the demon wears atsuita kimono meaning that he is similar to powerful gods (aragami). The demon is not only righteous and powerful but also considered to be of noble character.

As examined above, we can clearly see two different kinds of demons in Zeami's plays. One is a traditional demon with a rather fierce look in Ukai. This demon lives in hell and outside of the human realm. Zeami treated this demon as a powerful supernatural being from the outside. The other is a new type of demon Zeami created inspired by Zen Buddhist tradition, having human qualities. In their pre-existing source stories, these demons were harmful to humans and their characteristics differed from Zeami's reinterpretation of them. According to Zen's tenets and the Lotus Sutra, all creatures and even rocks, trees and the land in this world can attain enlightenment as humans can. The mountain hag and the nue monster have equal position in this world to humans. In his later career, Zeami integrated his learning of Zen Buddhism into his plays and created these new demons. Both mountain hag and nue were traditionally harmful beings, but Zeami transformed their representation according to Zen Buddhism and the Lotus Sutra. These religious tenets are the foundation for him to include these demons as having human qualities. Their masks and costumes represent this. The demons are parts of the world of reincarnation just as the humans are. This inclusion and empathy with the Other 
illustrate the ethos of Zeami's audiences in Yoshimitsu's cultural circle, who strove to include the cultural heritage of the aristocracy in the shogunate's hegemony.

\section{Costumes and Masks in Nobumitsu's Demon Plays}

In two of Nobumitsu's demon plays, the shite enters as a demon for the first time in the second act. Only the demon in Momijigari shares the same identity in both acts. This demon disguises herself as a human noblewoman in the first act, and appears in her true form in act two.

In Momijigari, the shite actor appears on stage as a noblewoman in the first act.

The actor wears a mysterious young woman mask (zōonna 増女) with a woman's wig. ${ }^{176}$ This mask and wig are used for such roles as goddesses or heavenly maidens. ${ }^{177}$ The costumes include a white collar, an under kimono with printed foils (surihaku), an outer layer of embroidered silk Chinese weave (karaori) with red color (iroari 赤地), and a fan. ${ }^{178}$ Surihaku is used for any type of female characters. The red color of the Chinese embroidered kimono means the character is a young lady. Wearing this mask and costume, the character is clearly young, beautiful, and mysterious. The play script matches this description because, in the first act, this character never reveals her identity. She is very mysterious, enjoying a banquet all alone, with just her female maid servants deep in the mountain.

\footnotetext{
${ }^{176}$ For illustrations of the mask and costumes, see Figure 12 and 13 in Appendix B.

177 Yokomichi and Omote, Yōkyokushū Ge, p. 483.

${ }^{178}$ Sanari, p. 3080.
} 
In the second act, the shite actor appears on stage in demon form. The mask is a violent demon mask (shikami 䶦) with a red-haired wig (aka gashira 赤頭). ${ }^{179}$ The costumes are a light blue (hanada 縹) collar, a bordered twill-woven short sleeve kimono (dan atsuita 段厚板) underrobe, happi, hangiri hakama trousers, and a sash belt. ${ }^{180}$ As we saw in Nue, happi is worn by supernatural beings with a red hair or black hair wig. Hangiri trousers are for powerful characters. This demon also has a striking staff (uchizue 打杖). This striking staff is primarily a symbol of authority just as fans are. ${ }^{181}$ This striking staff is often held by demons and indicates their supernatural powers. This character's costume shows that she is a powerful supernatural being and the violent demon mask shows her nature as harmful to humans.

For Momijigari, there is an alternative direction ( $k a e$ 替エ) for a different costume. In this Momijigari's alternative direction, the demon wears a different mask. Momijigari's demon mask is one of the examples of plays having alternative directions, allowing two versions: violent demon mask (shikami) and female demon mask (hannya 般若). These different masks change how we interpret the play because demons depicted with shikami masks are very harmful demons while demons of hannya masks are fallen female humans, who have turned into demons. ${ }^{182}$ In other plays which have hannya masks, female demons are exorcized by either Buddhist monks or Shugendō practitioners. These plays include a shōdan sub-section called exorcism prayer (inori 1

\footnotetext{
${ }^{179}$ For illustrations of the mask and costumes, see Figure 14 and 15 in Appendix B.

180 Sanari, p. 3090.

${ }^{181}$ Yokomichi et al, Nō no Kōzō to Gihō, pp. 128, 134-136.

${ }^{182}$ For illustrations of the mask and costumes, see Figure 16 and 17 in Appendix B.
} 
ノリ), during which these monks and mountain wizard practice exorcism, summoning the power of Buddhas or deities using the rosary (juzu 数珠). Momiijigari does not have this maigoto. Most of these hannya demons are vengeful toward specific people. In Momijigari, Koremochi never met this demon before but the demon is so harmful that the demon tries to trick Koremochi by getting him drunk so she can kill him. Also, although this demon's body size is not as large as demons' in Rashōmon or Orochi, the size of the demon in Momijigari in play script is more than two meters, bigger than normal humans at that time. Considering these facts, Nobumitsu's original idea was to use the violent demon shikami mask for Momijigari's demon. ${ }^{183}$

In Rashōmon, the shite actor appears on stage in demon form in the second act. The mask is the violent demon mask (shikami) with a red-haired wig (aka gashira 赤 頭). ${ }^{184}$ The costumes are navy blue (kon) collar, a twill-woven short sleeve under kimono (atsuita), happi, hangiri hakama trousers, and a sash belt. This demon also has a striking staff (uchizue 打杖). ${ }^{185}$ The costume's color is different but this configuration is almost exactly the same as the demon in Momijigari.

In Orochi, the shite actor appears on stage in demon form in the second act. The mask is the black beard mask (kurohige 黒髭) with a red-haired wig (aka gashira 赤頭) and decorative head ornament of a dragon $\left(r y \bar{u}\right.$ 龍). ${ }^{186}$ The black beard mask is for dragon

\footnotetext{
183 Yokomichi et al, Nō no Kōzō to Gihō, pp. 258-259.

${ }^{184}$ For illustrations of the mask and costumes, see Figure 18 and 19 in Appendix B.

185 Sanari, p. 3355.

${ }^{186}$ For illustrations of the mask and costumes, see Figure 20 and 21 in Appendix B.
} 
gods. ${ }^{187}$ The dragon's ornament makes it clear this character is in the shape of a dragon.

These kinds of ornaments on actors heads are used to represent non-human creatures such as a crane, rabbit, or fox deity. The costumes are a navy blue (kon) collar, a twill-woven short sleeve under kimono (atsuita), happi, hangiri hakama trousers, and a sash belt. This demon also has a striking staff (uchizue 打杖). ${ }^{188}$ Except for black beard mask and dragon ornament on the head, this costume matches with the demons Momijigari and Rashomon. Because the great serpent shares the snake-like appearance with dragon gods, Nobumitsu used this costume configuration. Nonetheless, the serpent is depicted as an evil character regardless of its physical resemblance to dragon gods.

As examined above, we can see two different kinds of demons' visual representations in Nobumitsu's play. One is a very harmful demon with a fierce look, wearing the ferocious shikami mask. These demons attempt to kill humans whenever the demons see humans. The other has a dragon-like appearance with the black beard mask. Nobumitsu utilized this appearance in many plays in which dragons appear. However, the characterization by plot and play script add evil quality to this god-like appearance of the great serpent. Later in history, noh actors added an alternative direction to the demon in Momijigari. In this direction, the demon has the appearance of female demon. This is a different interpretation of this demon's personality. Obsessed with vengeance, the demon attacks men including Koremochi because she is full of hatred and jealousy toward her lover. This portrayal inspired later writers to create a new back story for the Momijigari

\footnotetext{
${ }^{187}$ Yokomichi and Omote, Yōkyokushū Ge, p. 485.

188 Sanari, p. 3512.
} 
demon depicting her as a woman who was betrayed by her lover. ${ }^{189}$ In both cases, these masks and costumes show that the demons are powerful supernatural beings. This violent appearance and power along with the splendor of colorful costumes contribute to the stage spectacle. Although the costumes probably have changed from Nobumitsu's time, we can infer Nobumitsu's dramaturgy of stage spectacle from the traditional interpretation of these demons. This stage spectacle suited the social occasions produced by the powerful warlords in the Sengoku period.

\section{Small Stage Properties}

As in other forms of theater, performers use small stage properties (kodogu 小道 具) in performance. These properties are not meant to be realistic, and are usually made of bamboo, paper, cloth, or tree branches. Small stage properties in noh drama have conventions of stylistic patterns such as the use of fans in dance. These properties appear in many plays. However, how the actor uses these in dances determines the functions of these properties in plays. These properties are part of fixed choreography transmitted from generation to generation in each school.

Zeami's demons use fans, striking staffs (uchizue), and walking sticks (kasetsue). Performers in Zeami's plays use fans in their dances. Among Zeami's and Nobumitsu's demon noh plays, only demons in Zeami's plays have fans. As I explained above, people in the upper social class and actors held fans to show their authority. These fans have a variety of base-colors, drawings, and patterns. For demon characters, there is a special

\footnotetext{
${ }^{189}$ For example, see her origin story in Saitō, Kitamuki San Reigenki Togakushi san Kijo Momiji Taiji no Den, pp. 1-12.
} 
pattern painted on the fan. It is called an asura fan (shura ōgi 修羅扇). However, how these different varieties of fans are assigned to the characters differs among schools. ${ }^{190}$ Fans and striking staffs share the same function of creating a noble impression to audiences. The shite characters dance both kuse dances and maigoto, and manipulate their fans and staffs in various ways.

Zeami's demons never engage in combat with waki characters. Only two demons have staffs in Zeami's demon plays: the mountain hag in Yamanba and the nue monster in Nue. After appearing in demon form in the second act, the mountain hag performs a kuse dance. Before this kuse dance, she holds a walking staff from the time she enters the stage. Before she starts dancing, the stage properties assistant hands a fan to her. In noh plays, after the shite actor enters the stage, he stays there. If the play has two acts, he leaves once, to change costume. The stage assistant (kōken 後見) sits upstage. When the shite character exchanges his fan for a staff, the stage assistant takes the one and gives him the other. The mountain hag's staff is essential for tachimawari which shows how she suffers while wandering around in the mountains. Although these assistants stay on stage the entire time, they are not part of the plays' landscape, just as the musicians and the chorus are not.

Only the nue monster in Nue has a combat scene in a storytelling narrative. In this scene, using the fan and striking staff, the shite actor mimics actions by both the nue monster and Minamoto no Yorimasa. When Yorimasa receives the sword of honor from the emperor, the shite actor uses the striking staff to symbolize the sword. For Zeami, the

${ }^{190}$ Yokomichi et al, Nō no Kōzō to Gihō, pp. 131-132. 
striking staff, as well as fans, were useful devices for choreography while providing an authoritative image for the characters on stage.

In Ukai, Zeami utilizes a small stage property which is very specific to the context for the cormorant fisherman's ghost, who is played by shite actor. As the character shows how he did cormorant fishing by dancing, Zeami provided him with a torch (taimatsu 松 明). This torch is made of branches of Japanese bush clover (hagi 萩) cut into approximately fifty centimeters with red cotton or red hairs on the top, representing flame. $^{191}$

In Zeami's demon plays, the shite actors mainly use fans for dances. For some characters, there are some specific small properties such as the walking staff for the mountain hag in Yamanba and the torch for the cormorant fisherman in Ukai. These items are mainly for characterization and important dance sections.

None of the Nobumitsu's three demons have fans when they appear on stage in demon form in the second act. Instead of fans, Nobumitsu's demons have striking staffs in all three plays. These striking staffs have symbolic value to show the characters are supernatural beings and are often wielded by demons to demonstrate their supernatural powers. They hold these for a practical reason as well. These demons have to fight with waki samurai warriors who wield swords. The demons have to fight with something long to make it clear to the audience that they are in blade-to-blade combat with the warriors they are trying to kill. These combats take the form of exciting dance scenes.

191 Yokomichi et al, Nō no Kōzō to Gihō, p. 124. 
Nobumitsu also uses small stage properties which are important in advancing the plots in plays. In Momijigari, a supporting deity of Hachiman god gives a divine sword to Koremochi to fight with the demon in the second act. Koremochi could have fought with his own sword. However, the blessing of Hachiman deity and the divine sword have an important role in the play. Without this divine support, Koremochi would have remained asleep and vulnerable to attack by the demon. In Rashomon, the waki character Watanabe no Tsuna receives an imperial gold sign (kinsatsu) to erect at the Rashōmon gate as the proof of his inspection. Without this property, Tsuna can never leave the house of his lord Minamoto no Raikō because Tsuna goes to the gate on his own. He needs something to prove his righteous action whether the demon is there or not.

Compared with Zeami's demon plays, Nobumitsu used these small properties as parts of the overall plot. These properties are crucial to the plays because Nobumitsu's texts clearly mention these properties. For details of how these characters used properties in main dance sections, I will examine specific dance scenes in plays by both Zeami and Nobumitsu later in this chapter.

\section{Large Stage Properties}

In noh drama, there is no large stage set scenery on stage. The stage also does not have stage machinery as in other forms of theater. However, there are large stage properties (tsukurimono 作り物) in noh plays. These are properties with simple structures somewhat taller than the height of adult male actors. These properties are made of bamboo, thatching straws, tree branches, and textiles. For example, "mountain" (yama 山) and "mound" (tsuka 塚) is one hundred and eighty centimeters high. Two bamboo 
sticks are bent in the shape of character "U" and fixed in four corners of foundation square made of thick bamboo (daiwa 台輪) to create the shape of a mountain. The roof is made of a bamboo cap and thatched with small branches of broad-leaved trees such as holly trees (mochi 䵑). ${ }^{192}$ These properties are never meant to be realistic as in other theater forms. Because of their simplicity, these properties leave room for the audience to use their imagination to create scenes and scenery.

These kinds of large stage properties are not used in the Zeami's three demon plays I am examining in this thesis. There are many plays written by Zeami which have large stage properties such as a ship in the play Eguchi and a mound in Nomori. The play Nomori is a demon play by Zeami. In Nomori, there are lines in the script indicating that the demon character needs to have the mound property because the elderly male ghost needs to go back into the mound and reappear as the demon god afterward. For creating scenery in the three Zeami demon plays I am analyzing, the characters sing lines describing it, such as the dreadful and beautiful natural scenery in Yamanba. Zeami mainly wrote his texts to draw audiences' attention to the shite actors. When these large stage properties are not necessary on stage to effectively create his narrative, Zeami did not use these items.

Compared with Zeami, large stage properties were very important for Nobumitsu's dramaturgy. Just as Nobumitsu tried to accomplish stage spectacle with a large number of characters, Nobumitsu also differed from Zeami's conventions in using these stage props. Nobumitsu made sure to place large stage properties which represent

${ }^{192}$ Yokomichi et al, Nō no Kōzō to Gihō, pp. 102, 107. 
the landscape specific to his plays. Probably due to the space constraint of noh stages, these stage properties are still small when compared with other theater genres such as kabuki. However, what Nobumitsu was doing was innovative for noh's tradition. He used these large stage properties as vehicles for actors to add more varieties of stage representation.

His characters often interacts with these landscape features. In Momijigari, the noblewoman disappears into the stage property of the mountain and comes out of it in the second act. This property is made up of two things. One is the "mountain" (yama) wrapped with dark fabric which has flowers on the top to symbolize autumn leaves in the mountain. ${ }^{193}$ The other is ichijo dai box (一畳台), which is a sturdy flat wooden box in the size of one tatami mat, wrapped with red textile on top and gold brocade textile on edges. $^{194}$

In Momijigari, this box is basically used to elevate the height of the mountain. It also creates space for the shite characters to perform on it in the combat scene. In Rashōmon, there are an ichijō dai box and shrine (miya 宮), made of bamboo and textile for its roof, to symbolize the Rashōmon gate. ${ }^{195}$ The waki actor's character Watanabe no Tsuna inspects the Rashōmon gate and the demon's hand comes out of the gate property. After that, the demon comes out of the property. Although this staging is more symbolic than actually scary, people still get terrified by imagining this dreadful demon's hand coming out of the darkness all of a sudden.

\footnotetext{
${ }^{193}$ For illustrations of the stage properties, see Figure 14 and 16 in Appendix B.

${ }^{194}$ Yokomichi et al, Nō no Kōzō to Gihō, pp. 103-104.

${ }^{195}$ For an illustration of the stage property, see Figure 18 in Appendix B.
} 
In Orochi, Nobumitsu used a sake-tub (sakabune 酒舟) to symbolize the tub full of alcohol (sake) to trick the great serpent. ${ }^{196}$ It is clear from just these three plays that Nobumitsu used a variety of large stage properties. Having large objects on stage such as these, Nobumitsu could enhance stage spectacle in his plays. Instead of describing scenery in singing without using properties, Nobumitsu effectively used these properties to stimulate audiences' imagination. Thus, large stage properties were crucial parts of his dramaturgy in order to support his spectacle and dramatic narratives.

\section{The Music in Dance Scenes (Drums, Singing, Rhythm, Structure)}

In chapter three, I examined the structures of demon plays' written texts to show how Zeami and Nobumitsu used important dance sections for characterization. For Zeami, music was the framework upon which playwriting was fashioned. ${ }^{197}$ The most impressive music sections of plays were often danced as well. In this chapter, I will focus on the direction and musical aspects of these dance sections because they are the most important parts of these demon plays.

\section{Play Scripts and Rhythm}

In noh drama, there are two kinds of verbal texts. One is sung or spoken independently from a set rhythm. In these sections of plays, either actors or the chorus sing freely, not following a set rhythm. Actors and chorus sing in a sonorous manner and

\footnotetext{
${ }^{196}$ The property is a tub called sakabune, which can literarily be translated as sake boat. For an illustration of the stage property, see the illustration 51 in Sanari, Yōkyoku Taikan Shukan.

${ }^{197}$ Kominz, "Premodern Playwriting Practices,” pp. 366-371.
} 
combine some elongated syllables occasionally. Another example is mondō dialogue scene in plain language. This dialogue scene is not sung but spoken without any melodies or set rhythm. The other kind of text is sung in time to a rhythm. As I examined in previous chapters, kuse sections have a clear and strong rhythm to which the chorus sings and actors dance.

For these texts with rhythm, there are three types of rhythm; hiranori, chünori, and onori. Hiranori (normal rhythm, 平ノリ) is the rhythm of three syllables per two beats. Chünori (middle rhythm, 中ノリ) is the rhythm of four syllables per two beats. Onori (big or strong rhythm, 大ノリ) is the rhythm of two syllables per two beats. Most scripts sung with rhythm are in hiranori rhythm. Parts in chünori rhythm are often mixed with hiranori rhythm. ${ }^{198}$ Characters and emotions are conveyed in part by the rhythms used when singing. Therefore, it is important to pay attention to whether performers are singing following a set rhythm or singing freely following no set rhythm. Furthermore, the powerful onori rhythm can be used to create a strong or wild impression. In this chapter, I will examine these texts to determine whether they are rhythmic or nonrhythmic - the distinction between hiranori and chünori is not important in this essay. In contrast, onori parts are clearly distinguished from the other two rhythms, creating a very clear and strong impression.

\section{Tone of Voice in Singing}

198 Yokomichi and Omote, Yōkyokushū Ge, p. 5. 
There are mainly two types of singing: yowagin and tsuyogin. ${ }^{199}$ Yowagin (subtle singing, ヨワ吟) is melodic singing in a smooth voice with basic pitch centers, low, middle, and high, with three notes between each pitch center. ${ }^{200}$ Tsuyogin is non-melodic singing in a stronger voice with two basic music notes, "low", and "middle" and "high" which are the same. Pitch intervals are sporadic and complex, so unlike European music. $^{201}$ Tsuyogin sounds like priests relentlessly chanting Buddhist sutras. The contrast between yowagin and tsuyogin indicates differences between masculine and feminine, joy and sorrow, high-spiritedness and thoughtfulness, and peacefulness and violence. ${ }^{202}$ Although this terminology (yowagin and tsuyogin) was established in the late seventeenth century, Zeami indicated clear distinctions between strong tones and subtle and melodic (yügen) tones. We cannot know the original singing due to the lack of detailed writing about music, and the obvious absence of recordings from the feudal era. I will use the contemporary music of noh drama for my analysis in this chapter.

By analyzing the rhythm and singing in plays, we can infer how Zeami and Nobumitsu intended to use music to create character and plot in each scene. This analysis allows us to understand their intentions more fully than reading the words of their scripts and ignoring music.

\section{Chorus Singing}

\footnotetext{
199 There is another type of singing named chügin 中吟 in b school, also called wagin 和吟 in Kanze school. This singing is a mixed part of tsuyogin and yowagin, or a tsuyogin part sung softly. See Yokomichi et al, Nō no Kōzō to Gihō, p. 86.

${ }^{200}$ Yokomichi and Omote, Yōkyokushū Ge, p. 6.

${ }^{201}$ Yokomichi and Omote, Yōkyokushū Ge, p. 6.

${ }^{202}$ Yokomichi and Omote, Yōkyokushū Ge, p. 6.
} 
In noh plays, there is always a chorus, a group of performers who sings a variety of verses. Unlike other forms of theater, the chorus members do not have any identities in the context of the world of the play. The chorus is a specialized group of performers who sing the verses of the narrator, and also express the words and thoughts of other characters in the play. The chorus sings when the narrator depicts landscapes or what is happening in scenes in plays. Also, the chorus sings for characters on stage, mainly the shite actors and the waki actors. Especially, when they perform dances, the chorus often sings their verses after these main actors begin to sing the first line of their verbal expressions, thoughts, or feelings. This way, the actors can concentrate on their performance of dances. This is especially valuable when the dance is physically challenging. The actors are further hampered by wearing tight wooden masks most of the time. The chorus is crucially important in my analysis of the music of demon plays.

\section{Use of The Taiko Drum}

One of the distinct musical characteristics in demon plays is that all six plays make use of taiko drums (taiko 太鼓). The taiko drum in noh is a shime daiko, with two leather heads tied to a round wooden body. The musician plays it with two wooden drum sticks. Relatively few noh plays require the taiko drum.

All noh plays require three instruments: kozutsumi drum, òtsuzumi drum, and nōkan flute. ${ }^{203}$ Kozutsumi is a small drum made with an hourglass shaped body and two leather heads that tie on with cords. The musician plays it with his right hand holding it

\footnotetext{
${ }^{203}$ For an illustration of musicians with instruments, see Figure 22 in Appendix B.
} 
over his right shoulder with his left hand. The rope (shirabe シラベ) securing the heads is slack enough that the musician can adjust the tightness by squeezing the ropes, thereby changing the pitch. The musician can create different sounds by hitting two different parts, the center and the edge, of the leather head as well. The otsuzumi is a slightly larger drum, similar in design to the kozutsumi. The musician plays it with his right hand, holding it on his left knee with his left hand. Because the rope is kept very tight, the musician cannot adjust the sounds of otsuzumi drum by squeezing the rope. There are only two different sounds, loud and quiet, made by hitting with different strength. The $n \bar{k}$ an flute (nōkan 能管) is a lateral flute of approximately forty centimeters with one blowing hole and seven fingering holes. The flute is made of bamboo. This nōkan flute makes a distinct high pitched sound. Most of the plays in programs are performed with these three instruments alone. However, demon plays usually have a taiko drum because taiko is often used to accompany onori rhythm.

When the musician plays taiko drum, it is always in onori (strong) rhythm. These sections with ōnori rhythm create intense and energetic singing and music. These sections usually appear only in the second act. Taiko drum is a significant part of the climax of plays, concluding a play, and sometimes a whole program of plays, leaving a strong impression.

Direction, Music, and Dance Movements in Zeami's Demon Plays

Noh drama is a holistic fusion of texts, singing, music, and dance. And, to understand a play, all elements must be understood in relation to all other elements. Because such analysis is complex, I will focus on just two plays Yamanba and 
Momijigari, the two most popular and influential demon plays by Zeami and Nobumitsu respectively.

Zeami used a kuse dance and maigoto as the main dances in Yamanba in order to create his narrative and characterization of the mountain hag, a supernatural character with human qualities. Specifically, I will focus on analyzing the kuse section and tachimawari section in the second act.

The shödan kuri, sashi, and kuse typically occur in this fixed order and constitute a set sequence in noh plays. According to Yokomichi, noh playwrights wrote their plays with sung lyrics at their foundation. ${ }^{204}$ They never wrote play scripts freely first, adding music and songs later. The shōdan kuri, sashi, and kuse have specific functions in noh plays. And, playwrights wrote verses to sing in each of three sections that would fulfill the functions required.

Table 7. Excerpt of Dan Sections in Yamanba

\begin{tabular}{|l|l|l|}
\hline Dan & Events & Major shödan \\
\hline 9 & $\begin{array}{l}\text { The mountain hag performs “The } \\
\text { Mountain Hag's Kusemai” }\end{array}$ & $\begin{array}{l}\text { Kuri (no fixed beat, tsuyogin), sashi (no fixed beat, strong } \\
\text { singing), kuse (fixed beat, tsuyogin) }\end{array}$ \\
\hline 10 & $\begin{array}{l}\text { The mountain hag performs dance } \\
\text { movement to depict her life in the } \\
\text { mountains }\end{array}$ & $\begin{array}{l}\text { Utai songs (no fixed beat, tsuyogin), tachimawari music } \\
\text { and dance (fixed beat, no singing) }\end{array}$ \\
\hline 11 & Finale & $\begin{array}{l}\text { Shite actor's singing (no fixed beat, tsuyogin), chorus } \\
\text { singing (fixed strong beat [onori], tsuyogin) }\end{array}$ \\
\hline
\end{tabular}

Source: Yokomichi and Omote, Yōkyokushū Jō, pp. 275-287.

In the kuse section, Zeami creates a beautiful image of the courtesan and the mountain hag singing and dancing "The Mountain Hag's Kusemai" together. In both acts of Yamanba, most of the singing is performed in the strong chant-like style (tsuyogin).

${ }^{204}$ Yokomichi et al, Nō no Kōzō to Gihō, pp. 80-81. 
Occasionally in the first act, the tsure character courtesan sings in the melodic style (yowagin). The courtesan's subtle and high pitched singing creates a contrast with the strong masculine style of the mountain hag. Although they are performing together, this kusemai becomes the personal narrative of the mountain hag.

The mountain hag uses a fan in "The Mountain Hag's Kusemai" dance. Right before this section starts, the shite actor gives the walking staff to the stage assistant, so that the shite actor can use a fan for dancing. After the whole kusemai scene is over, the shite receives the walking staff once again to dance tachimawari section. Also, in Nue, the nue monster dances using a fan in the kuse section. For Zeami, the fan was a very important part of the kuse dance, and helped to emphasize the demons' human qualities. Special hand-held properties such as the walking staff in Yamanba and the striking staff in Nue were also important parts of the unique characterization of each character.

Noh actors do not improvise when they dance, strictly following set choreography. These choreographies have been transmitted in master-disciple relationships, often between father and son. Although the tempo of performance and some details of movement changed as time went by, we can assume that the current choreography derives from the Muromachi period.

The structure of jo ha kyu plays a very important part of how plays progress. One of the examples of jo ha kyu structure is the combination of kuri, sashi, and kuse shōdan sub-sections. In “The Mountain Hag's Kusemai” section, kuri, sashi, and kuse are performed in sequence. Kuri and sashi sections do not have fixed rhythm and they are sung in strong style (tsuyogin). In the kuri section, while singing about how mountains and the ocean took their shapes, the shite character mountain hag goes to the center of the 
stage and sits on a stool (shōgi 床几). Then, in the sashi section, while sitting, the mountain hag describes the dreadful and beautiful landscape where she lives in the mountains quoting classical poetry and literature. Here, the mountain hag and the chorus take turns singing these verses although all these verses are the mountain hag's words.

The kuse shōdan is sung following a strong rhythm. It starts with the chorus singing the mountain hag's words about how quiet it is in the dense forests, with just occasional birds' singing in the mountains. Strong rhythmic drumming creates momentum for the dance and chorus' singing. When the mountain hag's verses sung by the chorus start to describe the subtle beauty and dreadfulness around her, the mountain hag stands up from the stool and starts dancing with a fan. As she dances using a fan, the verses describe how commoners and the mountain hag share earthly desires and dharma nature just as dreadful nature such as rocky mountains and beautiful nature such as green willow trees and red flowers both embody the Buddhist law.

After this kusemai is finished, the mountain hag demonstrates how she wanders in the mountains (yamameguri 山巡り). This dance is meant to present the comparison between "The Mountain Hag's Kusemai" dance and the real mountain hag's actual life. In this section, the mountain hag dances to music accompaniment only, and no lyrics are sung. Right before this section starts, the shite actor receives the walking staff from the stage assistant. The mountain hag starts beating the floor with the walking staff in time to the rhythm of the music. Then, she begins walking around on stage in a slow but firm manner. She goes to the downstage pillar at stage right first, and then goes around the stage in a counterclockwise direction to upstage center in front of the musicians. From there, she goes to the center of the stage and kneels down. Then, she turns around and 
goes to where she began her travels, near the end of the bridge passageway (hashigakari). After this dance, there is the section of the mountain hag's departing words to the tsure actor. The mountain hag states she is very sad to leave but she has to go. When wandering in the mountains, she appreciates beautiful nature such as flowers in spring. These parting words are poetic but very humane, and sound like words to close friends or family members. Indeed, the mountain hag states that this meeting was predestined from a past life.

The kuse section in Yamanba is a long kuse section called nidan kuse (two-step kuse, 二段クセ). Nidan kuse is a kuse section which has two independent verses sung separately by the shite actor. Learning from his father Kan'ami, Zeami utilized this kusemai as the main part of his narrative about demons. Also, he integrated a tachimawari, which has only musical accompaniment and no singing. This was likely inspired by "Tennyomai" of his rival Inuō. Having a very long kuse section and two tachimawari sections, Zeami skillfully integrated what he learned throughout his career into this play.

Before Zeami established this approach, he wrote his demon plays differently, mainly by following Yamato sarugaku tradition. In Ukai, the main section is the rongi section, or sung dialogue between the shite actor and the chorus. Expressive and intense dialogue was a significant element in Yamato sarugaku plays.

Table 8. Excerpt of Dan Sections in Ukai

\begin{tabular}{|l|l|l|}
\hline Dan & Events & Major shödan \\
\hline 8 & The King of Hell enters the stage & Issei (no fixed beat, tsuyogin) \\
\hline 9 & $\begin{array}{l}\text { The King of Hell and the traveling } \\
\text { monk engage in dialogue }\end{array}$ & Rongi sung dialogue (fixed beat, tsuyogin) \\
\hline
\end{tabular}




\begin{tabular}{|l|l|l|}
\hline 10 & Finale & $\begin{array}{l}\text { Kiri concluding dance with song and music (fixed beat, } \\
\text { tsuyogin) }\end{array}$
\end{tabular}

Source: Yokomichi and Omote, Yōkyokushū Jō, pp. 174-180.

In the second act, the King of Hell describes how he transformed the cormorant fisherman's boat into the boat of salvation as written in the Lotus Sutra. Then the monk (waki) and the King of Hell (shite) engage in a dialogue that praises the power of the Lotus Sutra. This is the rongi section, and the chorus sings the monk's verses. After this dialogue, the King of Hell dances a concluding (kiri キリ) dance while the chorus sings in the strong chant-like singing (tsuyogin).

As examined above, Zeami utilized these dance sections, their choreography, music, rhythm, tone of voice, use of stage properties in order to effectively characterize demons having human qualities. One of the apparent differences from Nobumitsu's demon is their long dialogues exchanged with the waki actors speaking in human languages even when they appear in demonic form.

Direction, Music, and Dance Movements in Nobumitsu's Demon Plays

As examined in the previous chapter, Nobumitsu used kuse section and combat scenes to create main high points in each act. In the first act of Rashomon, Nobumitsu also used mondo dialogue sections to create a tense argument as the high point of this act. Nobumitsu borrowed the approach that Zeami established by using kuse, maigoto, hatarakigoto sections, but moved further and created new approaches as well in his playwriting.

Here, I will analyze the direction, music, dances, other visual aspects of Nobumitsu's demon play Momijigari. Nobumitsu used the main dance sections in 
Momijigari in order to create his narrative of the harmful demon, who first appears in disguise as a sophisticated and beautiful noblewoman to deceive warrior hero Taira no Koremochi. I will focus on analyzing the dance in the first kuse section, and then the maibataraki section in the second act.

In the first act, there are a combination of kuri, sashi, kuse sections before the noblewoman dances in maigoto - jonomai and kyūnomai. Right before this dance section, the noblewoman attempts to prevent Koremochi from leaving. Koremochi agrees to stay and join the banquet under autumn leaves in the mountains.

Table 9. Excerpt of Dan Sections in Momijigari

\begin{tabular}{|c|c|c|}
\hline Dan & Events & Major shōdan \\
\hline 5 & The noblewoman's dance & $\begin{array}{l}\text { Kuri (no fixed beat, yowagin), sashi (no fixed beat, } \\
\text { yowagin), kuse (fixed beat, yowagin) }\end{array}$ \\
\hline 6 & The noblewoman dances & $\begin{array}{l}\text { Iguse (fixed beat, yowagin), sung poetry (no fixed beat, } \\
\text { yowagin), jonomai dance and kyünomai dance }\end{array}$ \\
\hline 7 & The noblewoman leaves the stage & $\begin{array}{l}\text { Rhythmic singing (fixed strong beat [önori], yowagin), } \\
\text { sung poetry }\end{array}$ \\
\hline- & $\begin{array}{l}\text { Ai-kyōgen: a deity appears in } \\
\text { Koremochi's dream }\end{array}$ & \\
\hline 8 & Koremochi waits & \\
\hline 9 & $\begin{array}{l}\text { The female demon enters the stage } \\
\text { followed by combat }\end{array}$ & $\begin{array}{l}\text { Rhythmic singing (fixed strong beat [önori], tsuyogin), } \\
\text { maibataraki dance with song and music (fixed beat, } \\
\text { yowagin), rhythmic singing (fixed strong beat [önori], } \\
\text { tsuyogin) }\end{array}$ \\
\hline
\end{tabular}

Source: Yokomichi and Omote, Yōkyokushū Ge, pp. 143-149.

In the introductory kuri section, the chorus sings Koremochi's words by recounting the story of Chinese monk Eon Hoshi. Eon made a vow not to leave his valley as part of his strict ascetic practice. When his two close friends came to visit him, Eon walked with them on their way home, chatting with his friends he walked along. Without thinking, he crossed a bridge at the border of his valley. Koremochi recites this story of Eon Hoshi to 
join the noblewoman's banquet as a sign of his gratitude because the noblewoman earnestly requests for Koremachi to stay with her. Although the waki character is a male samurai warrior, he sings this verse in subtle singing (yowagin) without fixed beats. This means this kuri section is meant to show Koremochi's romantic interest in the noblewoman. The shite character starts singing describing the beautiful landscape of autumn leaves, quoting a poem by Bai Juyi (772-846, Hakurakuten 白楽天) from Wakan Rōeish $\bar{u}$. In the middle of kuri section, the chorus again sings for Koremochi's words. The noblewoman and Koremochi share romantic feelings with each other.

In Zeami's demon plays, all the combination of kuri, sashi, and kuse sections are the shite character demons' verses. In Zeami's plays, the three sections presented three different parts of the protagonist's personal narrative. Here in Nobumitsu's play Momijigari, the chorus sings the verses of both the shite character and the waki character. Unlike Zeami's demon plays, we can see Nobumitsu chose to include other characters in this fixed combination of kuri, sashi, and kuse sections. Orochi is another example of his experiments with these sequenced sections. The kuri and sashi sections are verses by the shite actor's character Tenazuchi, the elder father of Lady Kushinada. In the kuse section, in the form of hearsay, Tenazuchi listens to the waki character Susanoo's long monologue sung by the chorus. In this scene, the shite actor dances although the verses are being spoken by the waki character Susanoo. This was Nobumitsu's early attempt to create smooth dialogue expressed in the sequence of kuri, sashi, and kuse sections. Borrowing the fixed convention of this combination of sections, Nobumitsu created more colorful dialogues in his dance section. 
I now return to the analysis of the kuse section in Momijigari. In this section, both the shite actor and the waki actor use their fans. In the beginning of the kuse section, the chorus sings the waki character Koremochi's verses.

Chorus:

And strangely beats his heart. More strangely still, for now

The wine his heart has loosed;

Resolved it should not pass his lips,

Yet once the cup is served, His mind is easily swayed.

Among Buddha's precepts there is one:

Commit the sin of drinking, And with it you will sin In lewdness and in falsehood. ${ }^{205}$

さなきだに人心。乱るるふしは竹の葉の。露ばかりだに受けじとは。思ひ しかど盃に。向へばかはる心かな。されば仏も戒めの。道は様々多けれ ど。殊に飲酒を破りなば。邪淫妄語も諸共に。乱れ心の花かづら。[... $]^{206}$

As the chorus sings the three clauses, the noblewoman goes closer to Koremochi to offer him alcohol, kneeling down in front of him. The shite actor uses the fan as her pitcher of sake. As the chorus sings the fifth clause "Yet once the cup is served," the waki actor receives the alcohol using his fan as a cup. In the next clause "His mind is easily swayed," two characters look at each other and the waki character Koremochi appears dazed by the noblewoman's beauty. As the chorus starts singing the line "Among Buddha's precepts there is one," the shite character goes to the center of the stage and starts dancing the kuse section. Here, while the chorus sings Koremochi's verses, the noblewoman dances. Koremochi states that if we break the prohibition of alcohol in the Buddhist tenet, we will break the commandment against adultery and untruthful speech.

\footnotetext{
${ }^{205}$ Nihon Gakujutsu Shinkōkai, p. 152.

206 Sanari, pp. 3086-3087.
} 
His heart is restless because of the noblewoman's superb beauty. He continues to say that he would feel embarrassed if somebody saw him now. After that, the shite character noblewoman starts singing her line, "So it is! Such is our fate." Then the chorus sings her lines. The noblewoman states that this meeting is predestined for both of them. She too has fallen in love with Koremochi. However, this occasion is as ephemeral as dew on the grass. She wishes to stay together forever, though she acknowledges that their acquaintance is too brief to allow it. Her heart is troubled because of these thoughts. This romantic and fantastic dialogue is sung in a fixed rhythm and in melodic singing (yowagin). Zeami wrote long monologues of confession in kuse section. Unlike Zeami's demon noh plays, Nobumitsu creates this beautiful dialogue exchange between lovers. After this scene of exchanged dialogue, the shite character flutters her long sleeves and starts dancing under the moon. These dances are maigoto: jonomai and kyūnomai. ${ }^{207}$ Jonomai is a quiet gentle dance. At the end of jonomai, the noblewoman starts acting suspiciously and checking if the waki character Koremochi has fallen asleep. After she confirms that Koremochi is sleeping, the dance changes into kyūnomai, a fastpaced dance with energetic music using taiko drum.

Even though no text mentions that the noblewoman is a demon trying to kill Koremochi at this point, the sudden change into this fast and tense music and dance clearly suggests that there is something suspicious about this beautiful woman. After this dance finishes, this fast tempo of strong rhythm (onnori) continues and the chorus starts singing about the sudden wind and storm in the night. Then, the chorus finishes this section with a song by the noblewoman. In a fixed rhythm and melodic singing, she sings

207 This jonomai is often replaced with chūnomai. Yokomichi and Omote, Yōkyokushū, p. 148. 
that waiting for the moon under the mountain's shade, there is much dew on your sleeves because you dozed off. Please dream on and do not wake up. The noblewoman goes around the stage and then goes into the mountain's stage property while repeating her line "Please dream on and do not wake up." This line by itself reads like gentle words to her lover. However, the sudden change into the onori rhythm and the stormy weather make this line sound ominous when we know the speaker is supposed to be a beautiful noblewoman. With this change to intense music and striking visual imaging, Nobumitsu skillfully crafted a foreboding scene to finish the first act. In the ai-kyōgen section, the kyōgen actor states that this noblewoman is a demon of the mountain. For a viewer who has never seen this play before, this is the first scene in which it is clearly revealed that the beautiful woman is a demon.

\section{Direction of Combat Scenes in Nobumitsu's Plays}

All three demon plays written by Nobumitsu have combat scenes. The two main characters, played by the shite actor and the waki actor, engage in the combat. These combat scenes are very consistent. Energetic instrumental music and singing support the actions of the combatants. The waki and shite attack and retreat in turns. Sometimes, just by reading the script, it is difficult to understand which character is doing what. When accompanied by directed and choreographed stage action, it is easy to see what is taking place.

In Momijigari, Koremochi fights with the demon after a deity wakes him up and gives him a sacred sword. Koremochi prays to the Hachiman deity, and draws the divine sword. Then, the demon jumps out of the mountain property and attacks him. When 
Koremochi stabs the demon, the demon tries to fly up while holding Koremochi's head, but Koremochi slashes at the demon. Afraid of Koremochi's sword, the demon climbs up a big rock. However, Koremochi pulls down the demon and runs it through with his sword.

\section{Chorus:}

Koremochi, undisturbed and unconfused,

Prays calmly in his heart:

Namu-ya Hachiman Dai-Bosatsu!

Unsheathes his sword and waits.

Intent on rending him to pieces,

The hag at once assaults.

Evading her, he in turn assaults

And drives her through the chest.

Gripping his head

The monster jumps to fly;

He cuts and cuts.

Frightened by his sword-blade,

She climbs the rock,

He pulls her down. He stabs her through

And kills the demon-hag; ${ }^{208}$

維持少しも騒ぎ給はず。南無や八幡大菩薩と(太刀を戴き)。心に念じ。剣 を抜いて(太刀を抜き)。待ちかけ給へば。微塵になさんと(シテ拍子を踏

み)。飛んでかかるを(台より飛下り)。飛び違ひむずと組み鬼神の眞中刺し 通す處を頭を掴んで上がらんとするを(とシテワキ組合ひ)。斬り拂ひ給へ ば劒に恐れて嚴へ上るを(シテ台に上り)。引き下ろし刺し通し忽ち鬼神を 従へ給ふ。209

This whole quote above is one long sentence. Japanese sentences can add as many

modifying clauses as the authors want. Within this sentence quoted above, there are many clauses describing the actions by two characters. Notes in parenthesis are added by Sanari in his anthology Yōkyoku Taikan, but these notes are not written in the play script. The underlined parts are the actions by the demons. The final predicate is the shitagae tamau

\footnotetext{
${ }^{208}$ Nihon Gakujutsu Shinkōkai, p. 156.

209 Sanari, p. 3091.
} 
従え給ふ meaning Koremochi conquered the demon, which shows the whole sentence is

from Koremochi's point of view. Reacting to the demon's attacks, Koremochi fights back and both characters attack and defend in turns. Reading the notes in the parenthesis helps us to understand what happens on stage as the chorus sings depicting these two characters' actions. Without actors' movement, this script is very difficult to understand. This fact clearly shows Nobumitsu wrote this script, assuming the close coordination of the chorus and the two main actors' actions on stage. Nobumitsu wrote scripts to make this progress in a smooth and time-efficient manner so that the combat happens with energy, speed, and momentum.

In Orochi, Nobumitsu uses the same strategy to depict the combat between Susanoo no Mikoto and the great serpent. Mikoto refers to Susanoo, and it means "the lord / the prince."

Chorus:

Mikoto draws his long, divine sword and when he comes down from the distant river bank, the great serpent is surprised and gets angry, but has fallen, drunk from the poisonous sake, losing his supernatural power, sprawled over mountains and rivers, (Susanoo) swings up his divine sword and slashes (the serpent), its tails scrape clouds and attempt to twine around Mikoto, but (Mikoto) escapes jumping when (the serpent) twines... (Mikoto) slashes (the serpent), when (the serpent) twines, (Mikoto) slashes (the serpent), when (the serpent) goes around, (Mikoto) goes around, mighty foes contest against each other, then the god displays his glorious power and slays the great serpent, where upon (Mikoto) takes a sword from the (serpent's) tail, and (Mikoto) names it Murakumo no Tsurugi. ${ }^{210}$

尊は十握の神劒を拔き持ち遥かの岸より下り給へば大蛇は驚き怒りをなせ ども毒酒に酔ひ伏し通力失せて。山河に身を投げ漂ひ廻るを神劒を振り上 げ斬り給へば。斬られてその尾は雲をうがち。尊を巻かんと覆へば飛び違 ひ。巻きつけば斬り拂ひ廻れば廻る。互の勢ひ神は威光の力を顕し大蛇を

\footnotetext{
210 The translation is by the author. Most subjects of the clauses are not written in the quoted Japanese text, and they are added in parenthesis in this translation.
} 
斬り伏せ忽ちに。その尾にありし劒をとつて。叢雲の劒とは。名づけたり 211

Again, this is one long sentence. However, in this play, Nobumitsu added more subjects in clauses unlike in Momijigari. The underlined parts are subjects mentioned in clauses. As a whole, this sentence has Susanoo as the subject two times (mikoto ha 尊は and kami $h a$ 神は) and the great serpent once (daija ha 大蛇は). This is more explanatory than what Nobumitsu wrote for the combat dance in Momijigari. In Rashōmon, Nobumitsu wrote his combat text using a similar approach to Momijigari. Considering Nobumitsu wrote Orochi in a very early stage of his career, it is apparent that Nobumitsu polished his approach to simplify the text and to let stage action speak in order to create stage spectacle. For Nobumitsu, fast-paced dance for the combat was very important. The improvements in his two later scripts shows how much attention he paid to the dynamics of action on stage.

\section{Direction of the Combat Scene in Zeami's Nue}

Out of Zeami's three demon plays, only Nue has a combat scene. But, this dance scene is performed by the shite character alone, with no adversary on stage. The nue monster dances to the chorus' singing. The waki character monk never performs or engages in the combat. The monk simply listens and observes the nue monster tell his story and perform the dance. Thus, this scene is never meant to be a real combat. It is rather a storytelling by the nue monster in remembrance. The source story is from The Tale of Heike. This tale became very popular after the monks started reciting it in a

\footnotetext{
${ }^{211}$ Sanari, p. 3513.
} 
storytelling style. Whether Zeami was inspired by this heikyoku tradition or not, the noh play Nue's narrative of combat scene is meant to be performed by a single actor.

Regarding dialogue in the combat scene, this combat scene is very similar to Nobumitsu's combat scenes. Neither the shite's nue monster nor his enemy Minamoto no Yorimasa exchange dialogue. The nue monster talks in human language throughout the play, expressing his emotions and recollections. However, Zeami wrote the combat scene very briefly without going into the feelings of the nue monster during the combat.

Nue monster (sung by chorus):

were of my evil doing too.

As I boasted all in fury, so suddenly, when least expected, I was deeply hit by Yorimasa's arrow point; all disguising powers gone, crashing downward smashing downward upon the earth I fell down, and in an instant I was destroyed and died. It seems I think,

Yorimasa shot more than an arrowhead for his lord; Heaven's punishment. $^{212}$ わが為すわざよと怒りをなししに。思いも寄らざりし頼政が。矢先に当た れば変身失せて。落々磊々と。地に倒れて。たちまちに滅せしこと。思え ば頼政が矢先よりは。君の。天罰を。当たりけるよと今こそ思い知られた ${\underline{れ^{213}}}^{213}$

In this confession section, all evaluative comments are in a recollective manner from the current nue monster's point of view. Thus, this is more about storytelling than showing

\footnotetext{
${ }^{212}$ Yasuda, pp. 433-434.

${ }^{213}$ Sanari, pp. 2390-2391.
} 
energetic combat scene for effect of stage spectacle as Nobumitsu intended in his demon plays. For Zeami, the combat scene was just a part of the demon's storytelling about his tragic experience.

\section{Demons in Plays by Zeami and Nobumitsu}

As examined in this chapter, Zeami and Nobumitsu used very different approaches in writing and staging demon plays. The play Ukai was an example of Zeami's demon plays in the early stage of his career. This play relied on expressive and intense sung dialogues, following Yamato sarugaku's tradition. In Yamanba and Nue, Zeami created a new approach that emphasized demons' human qualities. Adopting his father's kuse dance and his rival Inuō's abstract heavenly maiden dances, Zeami established a new sophisticated structure for noh drama. Zeami mostly utilized this structure in his mugen noh plays. The shite actor plays the role of the demons disguised as human in the first act who then reappear in their true demon form in the second act. Zeami utilized a two fold approach. The first is solo dances (kuse dances and dances in onori rhythm) by the shite actor using fans and unique small stage properties. The second is music and singing in monologues by the demons played by the shite actors and also by the chorus. Both music and dance express the complex characters of demons in Yamanba and Nue, and their yearning for Buddhist salvation.

Nobumitsu wrote his plays to create spectacle and to display a variety of characters. These characters dance and sometimes engage in the intense dialogues. Nobumitsu always finished his demon plays with combat scenes where the waki warrior hero kills the demon. Nobumitsu chose appropriate source stories in order to create 
conflict between powerful antagonists. Not only did Nobumitsu showcase these powerful demons and appealing warrior heroes, he consistently presented a large number of characters on the stage. Also, he always used large stage properties to suggest landscapes. These large properties represented the landscapes which are very specific to the scene established for each play. These landscapes help to characterize his demons and also created a colorful image on stage for stage spectacle. For combat with demons, Nobumitsu always utilized energetic up-tempo music with taiko drums. In Nobumitsu's demon plays, the demons never speak when they are in demon form and the chorus describes the combat in a very concise manner so that the actions are depicted without relaxing the tempo until the end of the play. Nobumitsu always finished the plays with a scene in which a great warrior kills an entirely malevolent demon. Nobumitsu's demons have no redeeming human qualities.

Zeami and Nobumitsu created very different demon plays by utilizing different dramaturgy and techniques to craft their plays. Zeami characterized demons having graceful human-like qualities. Zeami's audience appreciated these qualities of gracefulness. The acceptance of the Other, including demons, was the fundamental principle of Zeami's ethos as a writer. This characterization echoes the social and political policies of Ashikaga Yoshimitsu. He strove to integrate different cultures including aristocratic culture, Chinese culture, and different denominations of Buddhism. Nobumitsu characterized his demons as very powerful and shrewd. In his plays, heroic warriors kill these violent demons. Nobumitsu's spectacular combat scenes are a celebration of human ingenuity and bravery sometimes with the assistance of deities. These spectacular stages decorated with colorful stage properties, and the splendid beauty 
of his costumes were just right for performances presented by warlords in the Sengoku Period. They produced these events to impress allies, political rivals, and their own vassals. The violent solution and competitiveness of the era is expressed in Nobumitsu's characterization and dramaturgy. Both Zeami and Nobumitsu wrote plays which appeal to the aesthetics and ethos of their audiences. However, because the ethos among audiences shifted from Zeami's time to Nobumitsu's time, these two playwrights created very different demons. 
Conclusion

In this thesis, I examined characterization and dramaturgy in demon noh plays by comparing three plays each by Zeami and Nobumitsu. These two playwrights took very different approaches in their characterization and dramaturgy. Zeami’s noh plays are often referred to as mugen noh, or dream vision noh. In this structure of noh plays, the protagonist played by the shite actor first appears as a human-like character in the first act. In the second act, the protagonist comes back in its true supernatural form. Nobumitsu's noh plays are often referred to as furyū noh, or spectacle noh. In his fury $\bar{u}$ plays, Nobumitsu brought many characters to the stage, and they dance one after another. Nobumitsu used various means to create high points throughout his plays. By comparing their different approaches, I attempted to illustrate how these playwrights characterized their demons differently.

\section{Demon Noh Plays and Demons in Medieval Japan}

Demon plays have a unique and significant position in noh drama's tradition. Noh drama emerged out of the tradition of rituals at temples and shrines in present Nara Prefecture. Some of these rituals were meant to protect humans against evil spirits. The most exalted ritual performance in noh tradition is Okina, which Zeami describes in his noh treatise "Sarugaku Dangi." Buddhist institutions presented these performances of Okina to pray for the protection of the emperor's realm and for the abundant harvests. Yamato sarugaku troops were traditionally known for mimetic acting and plot-driven performances. These troops were also known for performing demon plays. In medieval setsuwa stories, demons often appear when sarugaku performances were presented. 
These setsuwa narratives show how much these sarugaku actors were associated with demons in people's mind.

There are five categories of plays in noh drama. Demon plays comprise the fifth category of noh drama's official program. Although this categorization was officially established sometime in the mid-Edo period, Zeami and Nobumitsu had these categories in mind when they wrote and performed plays in the Muromachi period. Demon plays are performed at the end of a day's program. According to the structure of jo ha kyu, each play had specific features and functions in the program. Demon plays are the $k y \bar{u}$ of the day's program, and usually have very energetic dances, singing, and music. This energy was suitable to finish the day's program leaving a great impression on audiences.

In noh plays, demons (oni) are a variety of creatures, but all are unlike modern Japanese demons. In the plays I analyzed in this thesis, there are many different creatures, including the mountain hag in Yamanba, the nue monster in Nue, the demons in Momijigari and Rashōmon, and the great serpent in Orochi. The fifth category of noh includes all of these demons. This fact shows that the concept of demons (oni) in the Muromachi period was very different from the modern concept of demons. In the Muromachi period, every creature except for humans and well-known animals were supernatural beings. When these supernatural beings are worshiped, they are gods. When these supernatural beings are not worshiped, they are demons. Thus, many creatures that people do not worship are demons. Noh plays included all these creatures as demons in fifth category plays.

Although these plays in the fifth category have a specific function of finishing the day's program, Zeami and Nobumitsu wrote their demon plays very differently. For 
Zeami, inspired by Buddhist tenets, demons have human qualities because all creatures including humans and demons can attain Buddhahood through the power of Buddhism. Zeami wrote his plays by providing important dances and singing for the shite actors who play the demons. In Zeami's noh plays, the protagonist demons sing and dance, providing a narrative about their lives and expressing the suffering in their souls. For Nobumitsu, demons are evil and harmful creatures that humans have to conquer using violent means. In addition to sophisticated singing and dance, Nobumitsu always staged combat between these demons and warrior heroes played by waki characters. The contrast between the solo dance in Zeami's plays and the combat scene in Nobumitsu shows different approaches to create their narrative about demons.

\section{The Different Ethos in Zeami's and Nobumitsu's Plays}

Noh playwrights wrote plays that they hoped would resonate with the aesthetics, tastes, and social values of their patrons. In "Sandō," Zeami explains that noh plays' source must be well-known among audience members. Audiences enjoy seeing stories they already know enacted and reinterpreted on stage. Zeami emphasized the artistic and performative qualities of well-known heroes. Even when Zeami wrote plays about samurai warriors in literary sources such as The Tale of Heike, he emphasized the artistic side of their lives such as playing flutes or composing poetry. This approach made his characters more suitable for stage performance.

In the first half of his career, Zeami had Shōgun Ashikaga Yoshimitsu for his patron and Nijō Yoshimoto was his mentor. Yoshimitsu was the unifier of the nation and the samurai leadership class. He was the third shōgun of the Muromachi bakufu. He 
strove to unify the nation by bringing the court and the samurai bakufu together. Nijo Yoshimoto lived in the age of the court nobility's decline. Because the monarchy and supporting nobility were deprived of their financial base, the imperial court was unable to function properly without financial support from the warrior class. Nijō Yoshimoto attempted to involve Ashikaga Takauji and Yoshiakira, Yoshimitsu's grandfather and father, in imperial court life. However, due to the complex nature of the court's social protocols, these two shōgun never became actively involved. In contrast, Yoshimitsu willingly participated in this lofty social milieu, thanks to receiving Yoshimoto's mentorship in the court's social rituals. Both politically and culturally, Yoshimitsu paid great attention to the court aristocracy as well as to the samurai class. He often presented cultural and ritual entertainment from for both classes, including noh performances, kemari competition, and linked verse poetry composition gatherings.

Yoshimitsu also funded many cultural activities in the foothills of the northern mountains (Kitayama) of Kyoto. The culture of his period is called Kitayama culture. Kitayama culture is characterized by the unification of the culture of samurai elites and the imperial court. Yoshimitsu was very active in creating this cultural heritage to solidify his sovereignty. As well as enjoying them himself, he often used these cultural events to host the guests of the imperial court, aristocrats, and samurai warrior lords. By doing so, Yoshimitsu strove to combine the military power of samurai class and the cultural prestige of the aristocracy in order to stabilize his bakufu administration. He was the unifier of the nation, politically and culturally, integrating these two different cultures in his reign. During his reign, Zeami established most of his playwriting approaches as well as his aesthetics of subtle beauty (yügen). 
In the latter half of Zeami's career, his patron became Ashikaga Yoshimochi, Yoshimitsu's son, after Yoshimitsu passed away. Because Yoshimochi was devoted to Zen Buddhism, Zeami was greatly influenced by Zen Buddhism. One of Zeami’s personal reasons to turn to Zen was that he needed Zen's terminology to articulate his approaches to play crafting, performing, and evaluation in his noh treatises. Zeami also wrote plays inspired by Zen tenets, as exemplified by plays such as Yamanba. In addition to this inspiration by Zen, there was a well recognized rival actor named Inuō, who was known for his sophisticated heavenly maiden's dance (tennyomai). This dance was abstract dance, with instrumental music accompaniment only, having no singing. Because he had to compete with Inuō, Zeami also integrated dances similar to this heavenly maiden's dance as maigoto dances in his plays. His father Kan'ami combined the tradition of Yamato sarugaku in expressive and evocative dialogues and monologues (mondō, rongi, kakeai) and compelling plots with new popular dance, kusemai. Both Kan'ami and Zeami used kuse singing and dance in their plays to express the deepest feelings of the main character. Zeami developed his aesthetics during the reign of Yoshimitsu and he integrated many performance techniques he learned through his career. Fusing all of these elements, Zeami established his sophisticated play structure, which revolutionized the approach that his peers and later noh playwrights used to write their works.

Nobumitsu's approach to writing plays is known as furyu noh-spectacle noh. He rejected almost everything Zeami had written about crafting noh plays. In his noh plays, Nobumitsu included many characters who engaged in dances and combat to create stage spectacle. In these spectacle noh plays, Nobumitsu depicted demons as having no human 
qualities. The resolution of the conflict in his plays is to have warrior heroes kill the demons. This preference for conquering the powerful supernatural demonstrates the different ideals of the samurai class in Nobumitsu's time from the cultural circle of Yoshimitsu and Zeami. The spectacular victories of powerful warriors was an artistic representation of samurai bravery and martial prowess.

Nobumitsu's career was in its prime after the decentralization of power following the Ōnin War, which eventually led to Japan's Sengoku Era in the late Muromachi period. Around this time in history, the overall social trend was gekokujo, or rebellion against authority. Under this social trend, all warrior lords, including Nobumitsu's patrons, often needed to create social occasions to invite their allies, vassals, and potential rival lords as well. These warrior lords had very different aesthetics from those who gathered around Zeami's patron Ashikaga Yoshimitsu and his mentor Nijō Yoshimoto. The extravagance of social events including noh play performances was important for the Sengoku-era warlords. The reliance on samurai warrior's power to defeat supernatural beings is apparent in Nobumitsu's demon plays. The waki character warrior heroes engage in combat with powerful demons and kill them at the climax of his plays. Unlike Zeami's plays, there is no personal storytelling of confession by the demons, telling how they suffer in hell. Nobumitsu's stage spectacle resonated with samurai warriors who were competing to increase their power and prestige. For them, presenting a grand spectacle and heroic, victorious warriors suited their performance needs - to impress potential followers and perhaps rivals. 
As examined above, Zeami and Nobumitsu expressed very different ethos in their demon plays. They used various literary sources and techniques to craft their plays. Most significant are their source stories, role assignments, play structure, characterization, and reference to preexisting poetry and prose writings.

Zeami's demon noh plays featured in this essay were based on a war tale (The Tale of Heike), and regional legends. Nobumitsu's demon noh plays were based on a regional legend, a war tale (The Tale of Heike), and Japanese mythology. Although there is little difference in their source genres, the important difference is how the two playwrights changed the source stories to create their original narratives about demons. With the exception of Nobumitsu's Orochi, both playwrights considerably changed the plot from the original source stories. Zeami depicted the human qualities of demons in his plays. Nobumitsu changed settings to make the plot better for the spectacular staging of his plays.

Zeami wrote his plays using the structure of mugen noh. Zeami's approach to writing plays is known for his positioning the shite actor at the center of the play. Zeami believed that the success of noh drama's performances all depends on how well the shite actor performs. All the other elements in his plays are supposed to support what the shite character does on stage. The waki actor is included in plays so that the waki can prepare scenes for the shite actor. Dances by the shite are the main sections of most of Zeami's plays. Most of Zeami's waki characters do not have an individual identity. They are usually anonymous traveling monk or other travelers. These waki characters establish the setting and context of the play and listen to the demon's storytelling and confession. 
When the waki characters urge the demons to speak about their stories, the demons start telling stories, and later dance.

Also, kyōgen actors in Zeami's play do not have significant roles in advancing the plot. In Zeami's plays, the waki actor and the kyoggen actor often engage in dialogue. In plain language, they provide a summary of what happened in the first act and speculate about what is coming up in the next scene. The ai-kyōgen in Yamanba is an atypical example of ai-kyōgen. The kyōgen actor explains how the mountain hag was born from different kinds of lifeless objects in the mountains. This explanation has nothing to do with the play and it seems to be meant to provide a humorous dialogue so that the audience can relax.

Compared with Zeami's role assignments, Nobumitsu used a very different approach. Waki and waki-tsure are individuals_-often well-known warrior heroes. One of the significant differences is his waki characters have a very strong presence on stage. These characters are Nobumitsu's vehicles to advance the plot. The waki characters also have clear and special identities. Two of the waki characters are warrior heroes and one is a warrior deity. These role assignments are very different from Zeami's approach, which mostly presents anonymous waki characters. In two of Nobumitsu's demon plays, Rashomon and Orochi, the shite's demon characters only appear in the second act. These demons appear on stage and start attacking the warrior heroes without speaking any human language.

In order to have compelling combat on stage, it is important to have powerful antagonists for the warrior heroes: ferocious demons. Just like in Zeami's plays, the shite actors play these demon characters. However, their characterization is completely 
different. After the demons appear on stage in the second act, they do not speak any lines of prose or verse. In Momijigari, Nobumitsu presented a demon disguised as a noblewoman in the first act. In this disguise, she is able to speak, and does so. However, this disguise is the skillful tactic of the demon to deceive the waki character, the warrior Taira no Koremochi. For Nobumitsu, demons were creatures to be killed in combat with powerful warrior heroes.

Nobumitsu created spectacular stage performances when writing his plays by borrowing the conventions of dance structures from Zeami. Nobumitsu established his own approach to creating main dance scenes. Nobumitsu usually used the kuse dance and maigoto dances in the first act to characterize other characters, or to prepare the context for the combat later in the second act. Nobumitsu required many characters to perform different kinds of dances one after another. He also included some ai-kyōgen sections to advance the plot as we can see in Momijigari. In the second act, with intense and energetic music and singing, the combat scene between the demon and the waki character finishes his play, leaving a strong impression.

\section{Directions and Theatrical Conventions}

As for direction, one of the most apparent differences between Nobumitsu and Zeami is that Nobumitsu included far more actors on-stage than Zeami did. Another example of Nobumitsu's techniques is the use of large stage properties to create visual spectacle and facilitate different kinds of movement to depict combat scenes. Nobumitsu included a variety of colorful landscapes, which the demons characters use on stage, including a mountain with autumn leaves in Momijigari, and a gate to represent the 
Rashōmon gate. Zeami usually did not use these kinds of large stage properties. Zeami probably did not use these properties because they can distract the audience from the shite character's performance.

By examining the masks and costumes, we can understand more about how noh actors have traditionally interpreted these characters. Although Zeami's demons have distinct appearances, they share the trait of having human qualities. The mountain hag in Yamanba is a creature of dreadful appearance with a human heart. The mountain hag mask has an old woman's face with golden eyes to show supernatural quality. She wears the costume of a powerful nobleman, suggesting her nobility and strength. The nue monster in Nue has a mask which represents a powerful supernatural being who can move very fast. His mask and costuming are a lot more like a monster. The demon in Ukai is a righteous demon who praises the power of the Lotus Sutra. His mask shows his non-harmful but powerful qualities. His costume is of warrior lords of high rank. The mask and costumes of Nobumitsu's demons show that there are two types of demon in Nobumitsu's plays. One is a harmful demon, who attempts to kill humans whenever it come across humans. This is demonstrated by a specific mask shikami, which represents a powerful and ferocious demon. Another is the violent great serpent, represented by the mask and costumes of dragon gods. These two types of demons do not have any particular reasons to attack humans. They attack humans because they are malevolent by nature in Nobumitsu's plays. However, when the demon in Momijigari disguises herself as a beautiful human lady, the demon does a perfect job of pretending to be a sophisticated noblewoman, with education in classical poetry and literature. Nobumitsu's demon in this play can attack and deceive humans through cunning tactics. 
Zeami utilized solo dance sections by the shite actor as the main high points of his plays. Zeami characterized demons having human qualities by effectively arranging his choreography, music, rhythm, tone of voice, use of small stage properties. One of the apparent differences from Nobumitsu's demons is their long dialogues exchanged with the waki actor in human language while they appear in demon form. Nobumitsu wrote his plays to create spectacle shows with a variety of important human characters. These characters dance and sometimes engage in intense dialogues. Nobumitsu always finished his demon plays with combat scenes where the waki warrior hero kills the demon. For these combat dances, Nobumitsu always utilized energetic music with taiko drums.

As examined in this thesis, Nobumitsu's demon noh plays had very different approaches to characterization and dramaturgy. Both Zeami and Nobumitsu wrote their plays so that their patrons would enjoy and present these plays for their social occasions. We know that social occasions among the ruling elite in medieval Japan almost always had political implications and import. The different approaches and representation of demons in their plays showed the shift in ethos among the samurai warrior class. In order to respond to emerging trend in socio-political values, Nobumitsu experimented with many aspects of noh drama to create new kinds of plays which emphasized current samurai values and stage spectacle.

\section{Zeami and Nobumitsu's Noh Plays Influence on later Japanese Theater}

Noh drama became the official ritual and entertainment for the governing and warrior class at the beginning of the Edo period (1600-1868). The government and powerful warrior lords (daimyō) provided patronage for noh schools by paying stipends 
to noh actors. These actors were supposed to perform for ritual and social occasions presented by these patrons. Noh schools thrived under this established status of the theater. But, this elite status restricted noh plays from being performed for commoner audiences except on very special occasions, such as rare subscription noh performances. ${ }^{214}$ However, the noh drama stayed popular in various ways. In the Edo period, not only warrior classes but also people of all classes practiced noh's singing under the tutelage of noh actors. Noh play scripts were published for all to read, and noh also provided inspiration for other forms of theater. We can see this inspiration and influence in kabuki theater, as well as the puppet theater, in the Edo and Meiji periods.

Approximately one century after Nobumitsu passed away, a woman called Izumo no Okuni (dates unknown) started performing a dance called kabuki odori (kabuki dancing). In the very beginning, Okuni borrowed musical instruments of $n o h^{215}$ and presented ghosts who came on stage. But the kind of characters and the stories of the plays she presented were significantly different. Okuni crossdressed as a man who visits pleasure houses. Okuni's troop's performance and costumes appeared very different from any performance people had seen before. Thus, people started calling this dance performance "kabuki," or "heterodox" (strange). Her performance was the dance of an avant-garde of this time. After the government prohibited the kabuki by courtesans ( $y \bar{u} j o$ kabuki 遊女歌舞伎) in 1629 and wakashū kabuki (若衆歌舞伎, juvenile men’s kabuki) in 1651, men's kabuki (yarō kabuki 野郎歌舞伎) became the only form of kabuki

\footnotetext{
${ }^{214}$ Subscription noh (kanjin noh) was a noh performance for fundraising for religious institutions. In the Edo period, the shogunate allowed noh troops to hold subscription noh performance to raise fund for their noh schools. Noh schools were allowed to present subscription noh only once for every leader (taifu 大夫) of the school in his lifetime.

${ }^{215}$ Suwa and Sugai, pp. 22-24.
} 
theater. ${ }^{216}$ It was very popular among people of the commoner classes. All the characters including female characters were played by adult men. This was the beginning of the current form of kabuki.

Upon the approval of adult, male kabuki, the government censored the contents of kabuki performance and ordered theaters to present dramas that had a plot (kyoggen zukushi 狂言づくし). Because kabuki performance was initially just a combination of various dances, skits, and side show acts, kabuki actors borrowed approaches to creating stage drama from other performative genres including noh, kyōgen, kōwaka mai plays, and especially puppet plays (ningyō jōruri). ${ }^{217}$ Prior to the Genroku era (1688-1704), the stage curtain was introduced to kabuki. With this invention, the kabuki performances could extend their plays to more than one act. This change led to the birth of multiple-act plays and the need for sophisticated playwriting. Kabuki playwrights searched for inspiration in pre-existing literature including noh drama when they wrote plays.

One important aspect of Genroku kabuki is that it began to present long multi-act plays, and its playwriting became much more complex. Around the Genroku era, kabuki became a large scale theater with a variety of stage sets and properties. The stage performance involved a variety of performers - thirty or more per production. Professional musicians specialized in singing and provided accompanying music. Their most important musical addition was the three-string shamisen, contributing to the unique melodic quality of puppet theater and kabuki. Most kabuki actors played character roles. They both acted and danced. The large numbers of performers on stage and flashy

\footnotetext{
${ }^{216}$ Suwa and Sugai, pp. 23-26.
}

${ }^{217}$ Suwa and Sugai, p. 15. 
dancing are much closer to Nobumitsu's noh plays than to Zeami's shite actor-focused noh plays. However, noh as a distinct performance genre was prohibited from the kabuki stage. A large part of the history of Edo period kabuki is the careful adaptation of noh so as to benefit from the characters and stories from noh plays without staging that was too close to noh drama which was prohibited by the government.

Noh scholar Sanari Kentarō argues that noh plays contributed to the popularity of legends in folktales and pre-existing literature. ${ }^{218}$ Zeami created a mountain hag who is attractive and like a human, which was very different from the mountain hag's stories Zeami had read. The human-like mountain hag became the mountain hag that every Japanese knew. Momijigari was different. The story about a demon in Togakushi mountain was unknown before Nobumitsu wrote his play Momijigari. Pre-existing texts did not exist prior to this noh play. This noh play contributed to the popularity of Togakushi mountain as a tourism destination for autumn leaf viewing in the Edo period. Returning to the mountain hag, great playwrights could take Zeami’s humanized mountain hag and move her in all sorts of new directions. They could even have her appear in cities. She became the mother of Kaidōmaru, often known as Kintarō. ${ }^{219}$ Kaidōmaru later became Sakata Kintoki, one of the four powerful retainers of Minamoto no Raikō. A prominent kabuki and puppet play writer Chikamatsu Monzaemon (16531724, 近松門左衛門) looked for inspiration in noh plays to write his kabuki and puppet plays. In his puppet play Komochi Yamanba (嫗山姥, Mountain Hag Mother), a

\footnotetext{
218 Sanari, p. 3080.

${ }^{219}$ For an example of illustrations of this humanized mountain hag in the Edo period, see Figure 5 in Appendix A.
} 
courtesan named Yaegiri becomes the mountain hag. This mountain hag is a young

woman. She was a courtesan and married a samurai named Sakata no Kurando Tokiyuki. However, Tokiyuki left her to complete his revenge on the man who killed his father. He disguised himself as a tobacco peddler and traveled around searching for his foe, but all in vain. When Yaegiri meets him again, she tells to Tokiyuki that Tokiyuki's sister Shiragiku killed the murderer. Tokiyuki feels so ashamed that he commits suicide. Upon his death, he lets Yaegiri drink his blood. Then, his soul reincarnates in the womb of Yaegiri as a powerful boy, Kaidōmaru. Yaegiri gives birth to Kaidōmaru in the mountains and raises him there. This is how the courtesan Yaegiri became the mountain hag. Inspired by Zeami's human-like mountain hag, Chikamatsu created this human origin story for the mountain hag.

Chikamatsu also wrote another puppet play Momijigari Tsurugi no Honji 栬狩剣 本地, inspired by the noh play Momijigari. This play is the origin story of the sword Taira no Koremochi receives from the Hachiman god in Togakushi mountain. Koremochi is the main character in this play. Koremochi kills a monster who was attacking the imperial palace, and receives a sword from the emperor. Unlike the noh play Momijigari, he receives the imperial order to conquer the demon in Togakushi mountain. However, the sword Koremochi received from the emperor falls into the hand of his retainer and related members. For them, it is a cursed sword bringing bad luck and death, and it passes from family to family. When Koremochi goes to Togakushi mountain, he receives the sword from a ghost. In another Chikamatsu's play Shuten-dōji Makura Kotoba, Minamoto no Raikō receives this sword after Koremochi's retainer gives this sword to Raikō's retainer. Using this sword, Raikō successfully slays the demon Shuten-dōji. 
Chikamatsu needed good characters for his plays. He found many of them in noh plays and used and reshaped them in his own plays.

In addition to appearing in complete plays, the characters from noh plays appeared on stage during the kaomise kyōgen. Kaomise kyōgen is a special exhibition performance at the beginning of the kabuki season. ${ }^{220}$ This performance had all the actors appear on stage so that audiences would know which actors were performing during upcoming kabuki season. For these exhibition performances, the main playwrights determined the world (sekai) in which all the characters appear. ${ }^{221}$ These characters often included characters from noh plays. One of the major worlds was the world of Raikō and his shitennō (Raikō's four heavenly kings), which mostly featured the four powerful retainers of Minamoto no Raikō. In these performances, Watanabe no Tsuna was the warrior hero who slew the demon at the Rashōmon gate. He appeared on stage holding the signboard given him by Lord Raikō that he placed at the Rashōmon gate as a proof of his investigation. ${ }^{22}$ Close to the end of this performance, Tsuna was always seized by a demon who pulled him up by the hair on the back of his head. In this world, Yasumasa also became a popular character. In this performance, while Yasumasa plays a flute walking under the moon, he runs into a bandit called Hakamadare (袴垂れ, the hanging hakama trouser).

Kabuki Adaptation of Nobumitsu's Noh Plays in the Modern Period

\footnotetext{
${ }^{220}$ Hattori et al, p. 95.

${ }^{221}$ Hattori et al, p. 95.

${ }^{222}$ Kawatake and Furuido, p. 845.
} 
In 1840, a kabuki playwright Namiki Gohei wrote Kanjinchō 勧進帳, which was a kabuki adaptation of the noh play Ataka 安宅, for kabuki superstar, Ichikawa Danjūrō VII (1791-1859). This was the first time for kabuki to adapt noh plays and present them using many of the stage and costuming conventions of actual $n o h .^{223}$ It was risky for Danjūrō VII, the most famous actor at this time, because it was so close to the noh play. Danjūrō VII engaged a cotemporary noh actor to collaborate with him and they used the pine tree backdrop, the costuming, and some of the music from the noh play. There was a possibility that Danjūrō might be punished for doing this. Until this time, kabuki actors did not perform noh performances or close adaptations because it was prohibited by the government. When kabuki playwrights created kabuki adaptation of noh, they needed to make major changes in the plays and move them away from the staging and conventions of noh plays. This is what Chikamatsu Monzaemon and later kabuki playwrights did. They could keep characters, their characterization, and basic plot. However, they could not keep the music, dance, and costumes. They could not make a discrete kabuki play that begins and ends where the noh play does. They had to change and replace these aspects of the noh plays. Danjūrō VII's Kanjinchō challenged these taboos. Its performance was allowed and Danjūrō VII was not punished, but initially Kanjinchō was unpopular. Danjūrō performed it again and Kanjinchō became progressively more and more popular with each performance.

After the Meiji restoration (1868), kabuki playwrights could finally freely produce kabuki adaptations of noh plays, known as matsubamemono (松羽目物, pine

\footnotetext{
${ }^{223}$ Hattori et al, pp. 130, 366-367.
} 
panel plays). ${ }^{224}$ These are called matsubamemono because, like Kanjinchō, they have a pine tree decoration on the back screen that looks like the painting of a pine tree on the back wall (kagamiita) of noh stages. Kawatake Mokuami (1816-1893) wrote kabuki plays around the time of Meiji restoration. Active from the end of the Edo period, Mokuami is considered to be the kabuki playwright who bridged the Edo period and the modern period. He chose his favorite noh and kyōgen plays, adapted them, and put them on stage as matsubamemono.

In 1887, nineteen years after the Meiji restoration, Mokuami wrote a kabuki dance drama, Momijigari by adapting Nobumitsu's noh Momijigari. Even after the Meiji restoration, noh actors were reluctant to share their performance secrets with kabuki playwrights including Mokuami. ${ }^{225}$ After several trials, Mokuami gained access to directing secrets by getting support from noh's Kongō school. Because this kabuki is a close adaptation, there is no significant change in plot between the original noh and kabuki Momijigari. However, most of the staging follows kabuki's conventions, including singing, acting, dance, facial make-up, stage properties, and stage sets.

Four years earlier, in 1883, Mokuami wrote Ibaraki 茨木, a kabuki play which is a more distant adaptation of the noh play Rashōmon. In this kabuki play, the demon at the Rashōmon gate is called Ibaraki-dōji 茨木童子. After slashing off one of Ibaraki-dōji’s arms, Tsuna keeps the arm. The demon disguises herself as the aunt of Tsuna and visits him to get back her arm. In the play, she dances in human form with one arm. Right after taking back her arm, the demon reveals her true identity and escapes from Tsuna. The

\footnotetext{
${ }^{224}$ Hattori et al, pp. 366-367.

${ }^{225}$ Kawatake and Kawatake, p. 416.
} 
play uses the pine tree back screen. Mokuami added more materials from the original story ("Tsurugi no Maki") that had not been in the noh play. Mokuami also wrote two other plays based on the world of the Minamoto no Raikō's shitennō (four heavenly kings): Modoribashi (1890) and Tsuchigumo (1881). In these plays, Tsuna and other retainers fight demons in spectacular battles. Tsuchigumo (dirt spider) is a kabuki adaptation of noh play Tsuchigumo. Mokuami took these characters and stories from noh plays and turned them into kabuki dance dramas. Even at the present time, these plays are among the most frequently performed dance dramas in the kabuki repertoire.

As examined in this thesis, Zeami created a unique perspective on interpreting demonic characters. He established an orthodox approach to creating and staging noh plays. Two generations later, Nobumitsu experimented with new approaches to writing and directing noh plays. New developments in Nobumitsu's noh plays made his plays more kabuki-like than Zeami's plays were. Kabuki assimilated noh drama's aesthetics by adapting some noh and kyōgen plays throughout its history. These plays provided unique characters and stories suitable for stage spectacle in kabuki and puppet theater. As early as the late Muromachi period, Nobumitsu was re-shaping theater and preparing Japanese theater to plant the seeds of Edo-period kabuki theater.

Zeami's demon plays express the ethos of unification with and sympathy toward the Other-his "non-human creatures." In these plays, we see reflected the aesthetics and social core values of the ruling elite in the mid-Muromachi period. This is the legacy of the cultural circle including Nijō Yoshimoto, Zeami’s patron Ashikaga Yoshimitsu, and later Zeami’s Zen study during the reign of Ashikaga Yoshimochi. The three demon plays analyzed in this essay are still popular in the noh repertoire. Nobumitsu's demon 
plays partake of the ethos among the warlords in the Sengoku Era. These warriors had to demonstrate their power and prestige among allies, vassals, and rivals. They relied on their power to survive and even to conquer their enemies. Momijigari is one of the most frequently performed noh plays. Rashōmon and Orochi are less frequently performed but they are still included in most noh schools' repertoire. These plays include stage spectacle that not only impressed samurai warriors in the Sengoku period but also commoners in the Edo period, and even viewers who go to see noh performances today. Although noh drama has highly restricted staging conventions, there is in fact tremendous breadth of different approaches to playwriting, choreography, costuming, and use of properties. This comparative study of Zeami's and Nobumitsu's demon plays demonstrates this wide spectrum of creative approaches to noh drama and shows that these differences result from the changing values and ethos of noh patrons at different times in the Muromachi period. 


\section{Works Cited}

\section{A. Primary Sources (Versions Used, by Title)}

“Fūshikaden 風姿花伝,” Zeami. In Omote, Akira and Shuichi Kato, editors. Zeami Zenchiku.

“Kashū no Uchi Nukigaki 花習内抜書,” Zeami. In Omote, Akira and Shuichi Kato, editors. Zeami Zenchiku.

Momijigari 紅葉狩, Nobumitsu. In Sanari, Kentarō. Yōkyoku Taikan.

"Nikyokusantai Ningyōzu 二曲三体人形図," Zeami. In Omote, Akira and Shuichi Kato, editors. Zeami Zenchiku.

Nue 夜鳥, Zeami. In Sanari, Kentarō. Yōkyoku Taikan.

Orochi 大蛇, Nobumitsu. In Sanari, Kentarō. Yōkyoku Taikan.

Rashōmon 羅生門, Nobumitsu. In Sanari, Kentarō. Yōkyoku Taikan.

"Sandō 三道," Zeami. In Omote, Akira and Shuichi Kato, editors. Zeami Zenchiku.

“Sarugaku Dangi 申楽談儀,” Zeami. In Omote, Akira and Shuichi Kato, editors. Zeami Zenchiku.

“Shindai Jo 神代 序.” Nihon Shoki. Vol. I, edited by Noriyuki Kojima et al., pp. 17-107. Tokyo: Shōgakukan, 1994.

“Tsurugi no Maki 劎巻.” Heike Monogatari. edited by Kazutaka Nagai, pp. 1-32. Tokyo:

Yūrindō Bunko, 1927.

Ukai 鵜飼, Zeami. In Sanari, Kentarō. Yōkyoku Taikan.

Yamanba 山姥, Zeami. In Sanari, Kentarō. Yōkyoku Taikan.

\section{B. Secondary Sources and Translations}

Bethe, Monica, and Karen Brazell. Yamanba: the Old Woman of the Mountains. Ithaca: Cornell East Asia Series, Cornell University, 2008.

Brazell, Karen, and James T. Araki. Traditional Japanese Theater: an Anthology of Plays. Columbia University Press, 1998.

Eguchi, Fumie. "Kanze Nobumitsu no Sakunō Katsudō." Engeki Kenkyu Sentā Kiyō VII Waseda Daigaku 21 Seiki COE Puroguramu <Engeki no Sōgōteki Kenyū to Engekigaku no Kakuritsu>, 2006, pp. 11-17.

"ethos, n." OED Online, Oxford University Press, March 2019, www.oed.com/view/Entry/64840. Accessed 27 April 2019.

Goff, Janet Emily. Noh Drama and the Tale of Genji: the Art of Allusion in Fifteen ClassicalPlays. Princeton University Press, 1991.

Hare, Thomas Blenman. Zeami: Performance Notes. New York: Columbia University Press, 2008.

Hattori, Yukio., et al. Kabuki Jiten. Shohan. ed., Tokyo: Heibonsha, 1983.

Ikai, Takamitsu. Kiriainō no Kenkyū. Tokyo: Hinoki Shoten, 2011.

Ishii, Tomoko. Nō Kyōgen no Kiso Chishiki, Tokyo: Kadokawa Bungei Shuppan, 2009.

Kanze, Yoshimasa, et al. Supika Rōsoku Nō: Onizukushi no Futaya. Momijigari: Onizoroe. Tokyo: Zaidan Hōjin Bikutā Dentō Bunka Shinkō Zaidan, 2005. 
Kawatake, Mokuami, and Toshio Kawatake. Kawatake Mokuami Shü. Tokyo: Chikuma Shobō, 1966.

Kawatake, Toshio, and Hideo Furuido. Kabuki Tōjō Jinbutsu Jiten., Tokyo: Hakusuisha, 2006.

Kitagawa, Hiroshi., Bruce T. Tsuchida, and Edward Seidensticker. The Tale of the Heike = Heike Monogatari. University of Tokyo Press, 1977.

Komatsu, Kazuhiko. Hyōrei Shinkō Ron. Tokyo: Dentō to Gendaisha, 1982.

---. Oni to Nihonjin. Tokyo: Kadokawa Sofia Bunko, 2018.

Kominz, Laurence. "Premodern Playwriting Practices," A History of Japanese Theatre. edited by Jonah Salz, Cambridge University Press, 2016, pp. 366-375.

Lim, Beng Choo. Another Stage: Kanze Nobumitsu and the Late Muromachi Noh Theater. Ithaca: East Asia Program, Cornell University, 2012.

Mabuchi, Kazuo, et al. Konjaku Monogatarishū I. Dai 1-han. ed., Tokyo: Shōgakukan, 1999.

---. Konjaku Monogatarishū IV. Dai 1-han. ed., Tokyo: Shōgakukan, 2002.

Matsuoka, Shinpei. Chūsei wo Tsukutta Hitobito. Tokyo: Shinshokan, 2001.

---. Nō: Chūsei kara no Hibiki. Tokyo: Kadokawa Shoten, 1998.

---. Utage no Shintai. Tokyo: Iwanami Shoten, 2001.

Nihon Gakujutsu Shinkōkai. Dai 17 Shō Iinkai. Japanese Noh Drama: Ten Plays Selected and Translated from the Japanese Vol. II. Nippon Gakujutsu Shinkōkai, 1959.

Nose, Asaji. Nōgaku Genryūkō. Iwanami Shoten, 1938.

Ogawa, Takeo. Nijō Yoshimoto Kenkyū, Saihan. ed., Kasama Shoin, 2007.

Okuda, Osamu."Nijō Yoshimoto no Yūgen Ron," Nihon Bungei Kenkyū. Kwansei Gakuin Daigaku Nihon Bungaku Kai, vol. 10, no. 3, 1958, pp. 60-71.

Omote, Akira. Kanze-Ryū Shi Sankyū. Tokyo: Hinoki Shoten, 2008.

Omote, Akira, and Fumio Amano. Nōgaku no Rekishi. Iwanami Kōza Nō Kyōgen 1. Tokyo: Iwanami Shoten, 1987.

Omote, Akira, and Mikio Takemoto, editors. Nōgaku no Densho to Geiron. Tokyo: Iwanami Shoten, 1988.

Omote, Akira, and Shūichi Kato, editors. Zeami, Zenchiku. Nihon Shisō Taikei series Tokyo: Iwanami Shoten, 1974.

Owada, Tetsuo. Sengoku no Kassen. Tokyo: Gakushū Kenkyūsha, 2008.

Pinnington, Noel J. A New History of Medieval Japanese Theatre: Noh and kyōgen from 1300 to 1600. London: Palgrave Macmillan, 2019.

Reider, Noriko T. "Yamauba: Representation of the Japanese Mountain Witch in the Muromachi and Edo Periods." International Journal of Asian Studies, no. 2, 2005, pp. 239-264.

Sanari, Kentarō. Yōkyoku Taikan. Tokyo: Meiji Shoin, 1982.

Saitō, Ippaku, and Ikawa Seki, editors. Kitamukisan Reigenki Togakushisan Kijo Momiji Taiji no Den Zen. Tokyo: Tsujioka Bunsuke, 1886.

Senda, Yoshihiro. Nobunaga no Shiro. Tokyo: Iwanami Shoten, 2013.

---. Sengoku no Shiro wo Aruku. Tokyo: Chikuma Shobō, 2013.

Senda, Yoshihiro and Toshifumi Yata. Noto Nanaojō Kaga Kanazawajō. Tokyo:

Shinjinbutsu Ōraisha, 2006. 
Suwa, Haruo, and Yukio Sugai. Kinsei no Engeki. Kōza Nihon No Engeki. Shohan. ed., Tokyo: Benseisha, 1992.

Suzuki, Masataka. "On the Ritual Spaces in the Buddhist Ceremony Called Shuni-e at Todai-ji Temple.” Minzokugaku Kenkyu, no. 47, 1982, pp. 72-101.

Shimazu, Tadao. "Tōza no Bungei." Chūsei no Bungaku, edited by Jun Kubota and Tadahiko Kitagawa. Tokyo: Yūhikaku, 1976, pp. 237-248.

Shirane, Haruo. Japan and the Culture of the Four Seasons: Nature, Literature, and the Arts. Columbia University Press, 2012.

Takemoto, Mikio. "Zeami Jidai Izen no Nō no Kotaisei.” Kokubungaku Kenkyūu, no. 102, 1990, pp. 136-145.

Takioto, Yoshiyuki. "Yamata no Orochi to Seitetsu Shūdan." Izumogaku Tsūshin, no. 8, 2013, pp. 2-5.

Tokue, Gensei. "Zeami." Chüsei no Bungaku, edited by Jun Kubota and Tadahiko Kitagawa. Tokyo: Yūhikaku, 1976, pp. 254-259.

Umehara, Takeshi, et al. Nō wo Yomu IV. Shohan. ed., Tokyo: Kadokawa Gakugei Shuppan, 2013.

Varley, H. Paul. "Cultural Life in Medieval Japan.” The Cambridge History of Japan, edited by Kozo Yamamura, vol. 3, Cambridge University Press, Cambridge, 1990, pp. 447-499.

---. "Law and Precepts for the Warrior Houses." Sources of Japanese Tradition, 2nd ed., De Bary, Wm. Theodore, and Yoshiko Kurata Dykstra, New York: Columbia University Press, 2001, pp. 413-432.

Wakao, Itsuo. "Oni Densetsu no Kenkyū." Yōkai, Dai 1-han edition, edited by Ken'ichi Tanigawa, pp. 83-232. Tokyo: Sanichi Shobō, 1988.

Yasuda, Kenneth. Masterworks of the Nō Theater. Bloomington: Indiana University Press, 1989.

Yokomichi, Mario. Nōgeki no Kenkyū. Tokyo: Iwanami Shoten, 1986.

Yokomichi, Mario, and Akira Omote, editors. Yōkyokushū. 2 vols. Nihon Koten Bungaku Taikei 40, 41. Tokyo: Iwanami Shoten, 1960, 1963.

Yokomichi, Mario, Hisashi Hata, and Haruo Nishino, editors. Nō no Sakusha to Sakuhin. Iwanami Kōza Nō Kyōgen 3. Tokyo: Iwanami Shoten, 1987.

Yokomichi, Mario, Hiroshi Koyama, and Akira Omote, editors. Nō no Kōzō to Gihō. Iwanami Kōza Nō Kyōgen 4. Tokyo: Iwanami Shoten, 1987.

Yokoyama, Taro. "Tennyomai no Shintai Gihō," Zeami: Chūsei no Geijutsu to Bunka $<01>$, pp. 170-198. 


\section{Appendix A: Images of Demons and Monsters}

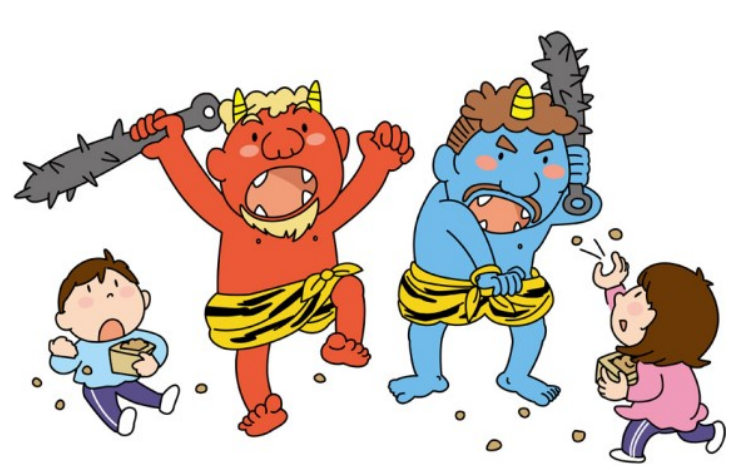

Figure 1. Demons and Children (Oni to Kodomotachi) by Public Domain Q, Japan. Following common ritual on a Setsubun Day, children are throwing beans at a red demon and a blue demon. Setsubun Day is celebrated one day before the first day of spring (Risshun Day). (Image courtesy of Public Domain Q.)

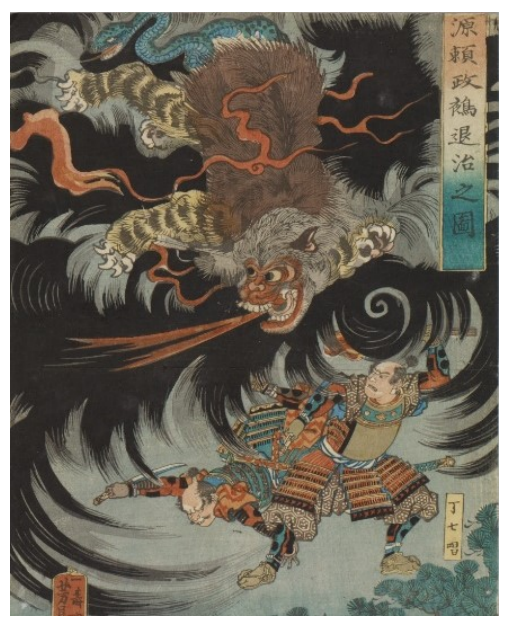

Figure 3. Minamoto Yorimasa Vanquishes the Nue (Minamoto Yorimasa nue taiji no zu) by Utagawa Yoshikazu, Japan, 1852. This segment of the color print (nishikie) shows retainers of Yorimasa when the nue monster comes out of a black cloud. (Image courtesy of The Tsubouchi Memorial Theatre Museum, Waseda University, ID Number: 012-1419.)

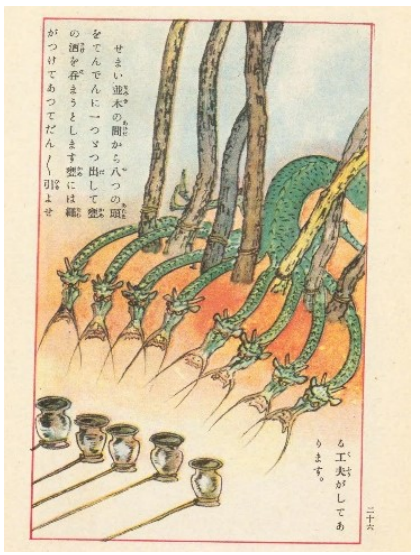

Figure 2. An illustration of Yamata no Orochi in Hozumi Tōten's picture book Susanoo no Mikoto, Japan, Maruzen, 1927. Yamata no Orochi comes to devour the image of Kushinada on the surface of sake in each vat and will be slain by Susanoo no Mikoto. (Image courtesy of National Diet Library Image Archives.)

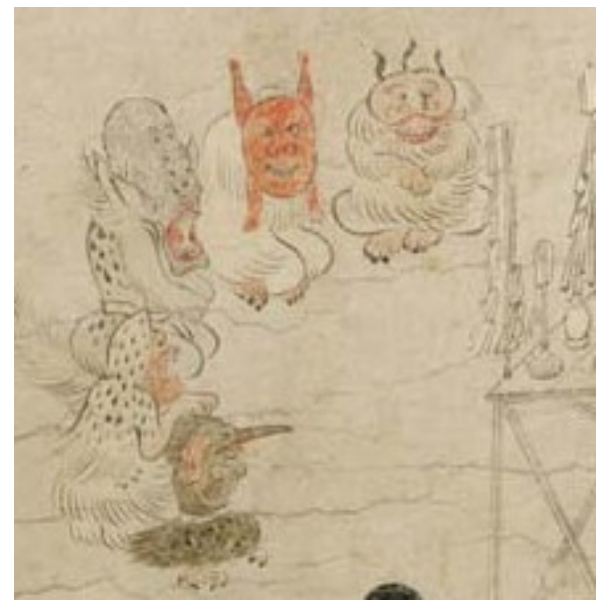

Figure 4. Fudō Riyaku Engi Emaki, Japan, 14thcentury. Different kinds of monsters are present when Onmyōdō specialist Abe no Seimei exorcizes them. The red-faced creature is a huge face washing bowl monster. (Image courtesy of Tokyo National Museum Image Archives.) 


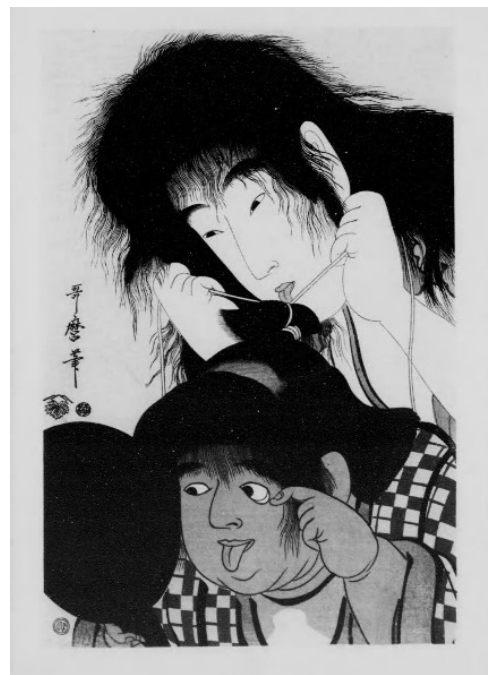

Figure 5. The Mountain Hag and Kintarō by Kitagawa Utamaro. The mountain hag is humanized and young, having somehow unkempt hair. (Image courtesy of National Diet Library Image Archives.) 


\section{Appendix B: Images of Masks, Costumes, and Musicians}

In this essay, the details about masks and costumes are cited from Yōkyoku Taikan. Sanari relied on various sources including the direction notes used by Kanze school. The masks shown are the same as explained in the essay. Because different schools and actors use some variations, costumes may differ from the items analyzed. However, the overall interpretation of characters stays the same nonetheless.

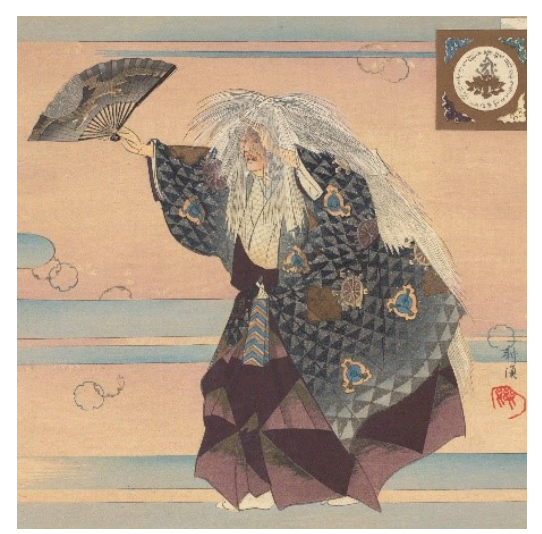

Figure 6. Yamanba in Tsukioka Kōgyo's picture book Nōgaku Zue Zenpen Ge, Japan, Matsuki Heikichi, 1898. The shite actor as the mountain hag in the second act. (Image courtesy of National Diet Library Image Archives.)

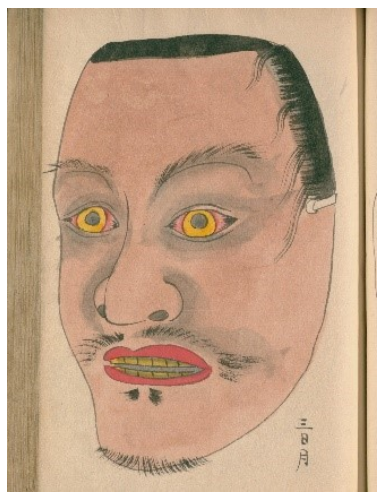

Figure 8. Mikazuki, male ghost mask, used in the first act of Nue. The shite actor plays the nue monster disguising himself as a boatman in the first act, wearing this mask. In the picture book Nōmen no Zu. (Image courtesy of National Diet Library Image Archives.)

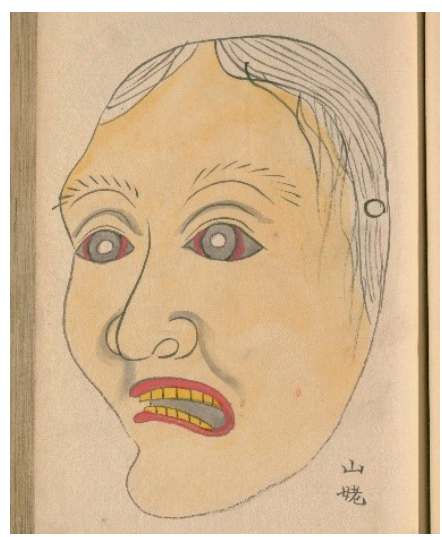

Figure 7. Yamanba, mountain hag mask, used in the second act of Yamanba. In the picture book Nōmen no Zu. (Image courtesy of National Diet Library Image Archives.)

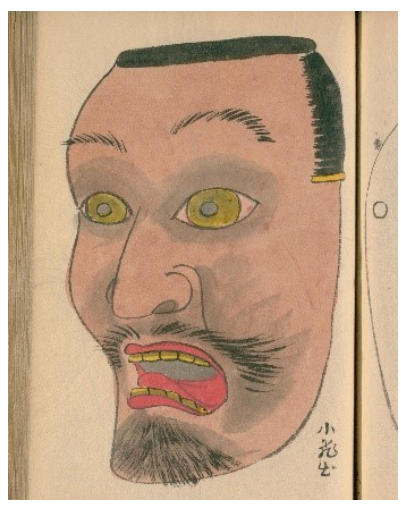

Figure 9. Kotobide, monster mask, used in the second act of Nue. The shite actor plays the nue monster in demon form in the second act, wearing this mask. In the picture book Nōmen no Zu. (Image courtesy of National Diet Library Image Archives.) 


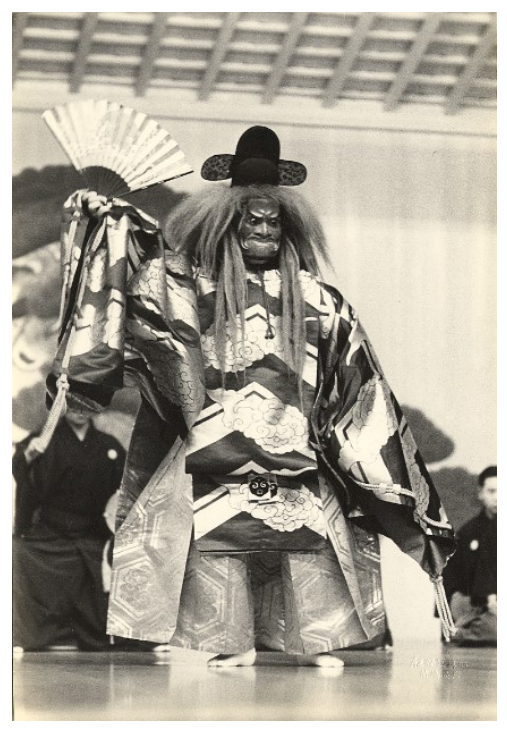

Figure 10. Ukai. The shite actor as The King of Hell in the second act. (Image courtesy of The Tsubouchi Memorial Theatre Museum, Waseda University, ID Number: FA1-03373.)

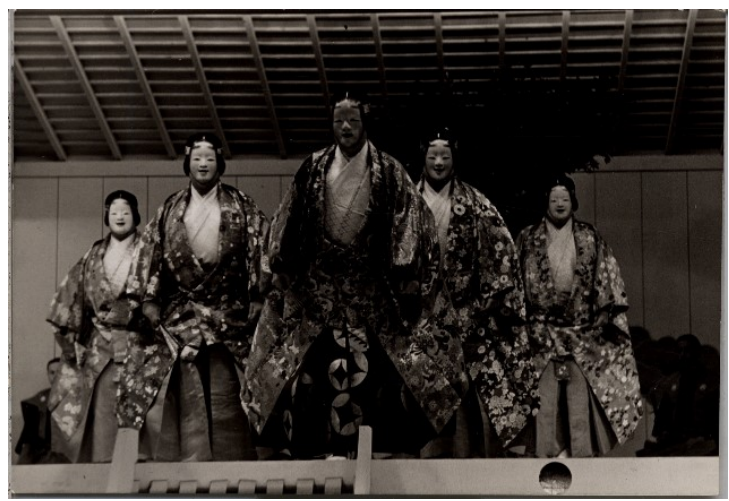

Figure 12. Momijigari. The shite actor in the middle plays the demon disguising herself as the noblewoman in the first act. The other four tsure actors play accompanying demons disguising themselves as the noblewoman's maids. (Image courtesy of The Tsubouchi Memorial Theatre Museum, Waseda University, ID Number: F6100577.)

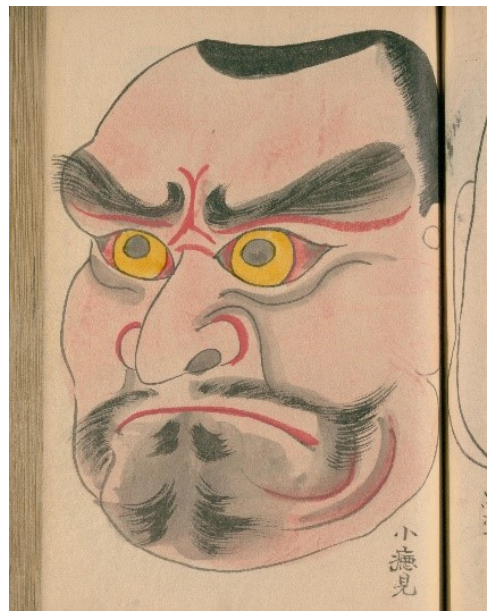

Figure 11. Kobeshimi, righteous demon mask, used in the second act of Ukai. In the picture book Nōmen no Zu. (Image courtesy of National Diet Library Image Archives.)

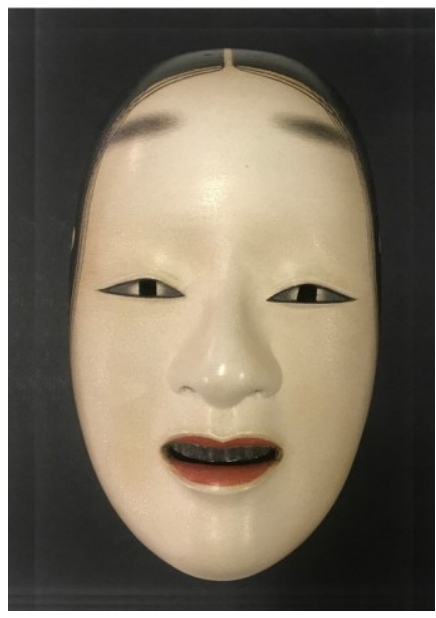

Figure 13. Zōonna, mysterious young woman mask used in the first act of Momijigari. (Courtesy of John and Peggy McAteer.) 


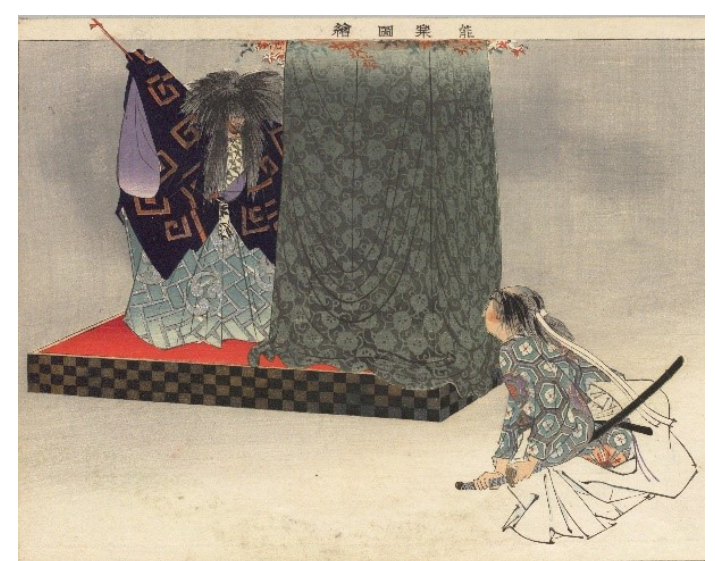

Figure 14. Momijigari in Tsukioka Kōgyo's picture book Nōgaku Zue Zenpen Jō, Japan, Matsuki Heikichi, 1901. The shite actor as the violent demon in the second act. (Image courtesy of National Diet Library Image Archives.)

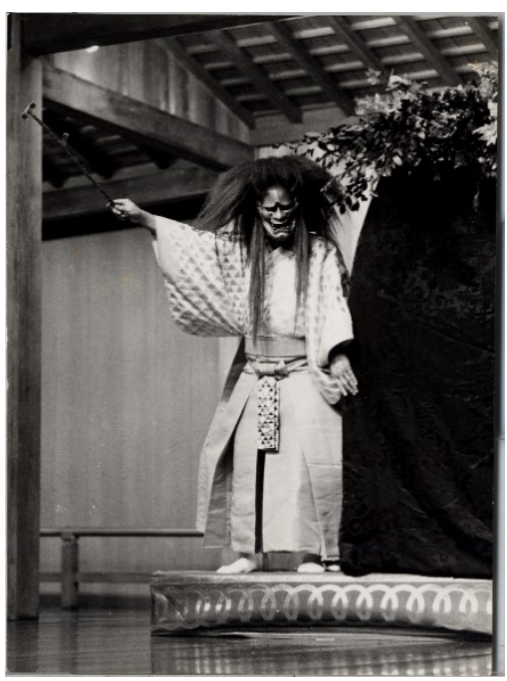

Figure 16. Momijigari. The shite actor as the female demon in the second act. This is an alternative direction of Momijigari. The shite actor stands by stage property of the mountain and ichijo-dai box. There are flowers attached to the mountain. (Image courtesy of The Tsubouchi Memorial Theatre Museum, Waseda University, ID Number: F61-00583.)

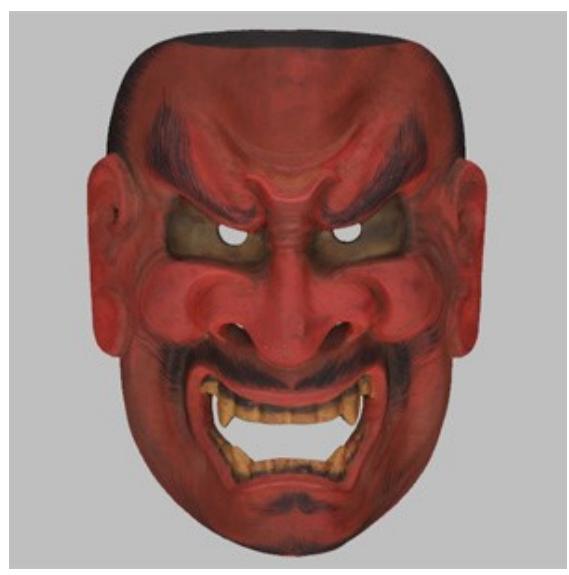

Figure 15. Shikami, violent demon mask, used in the second act of Momijigari. (Image courtesy of The Tsubouchi Memorial Theatre Museum, Waseda University, ID Number: 05639.)

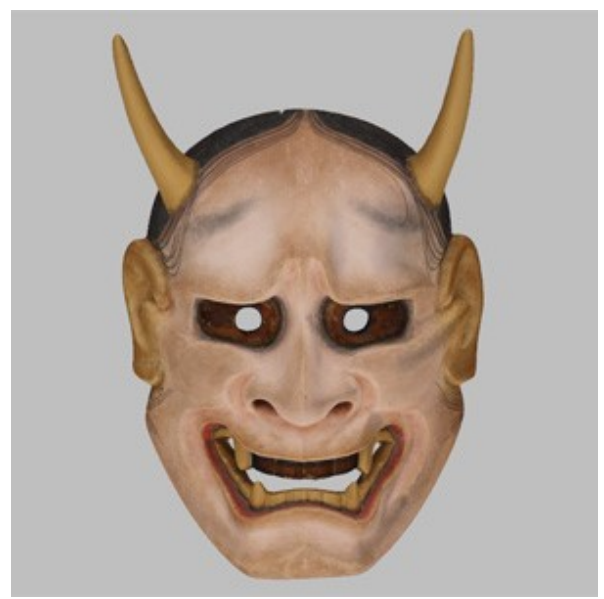

Figure 17. Hannya, female demon mask, used in the second act of Momijigari with the alternative direction. (Image courtesy of The Tsubouchi Memorial Theatre Museum, Waseda University, ID Number: 09095.) 

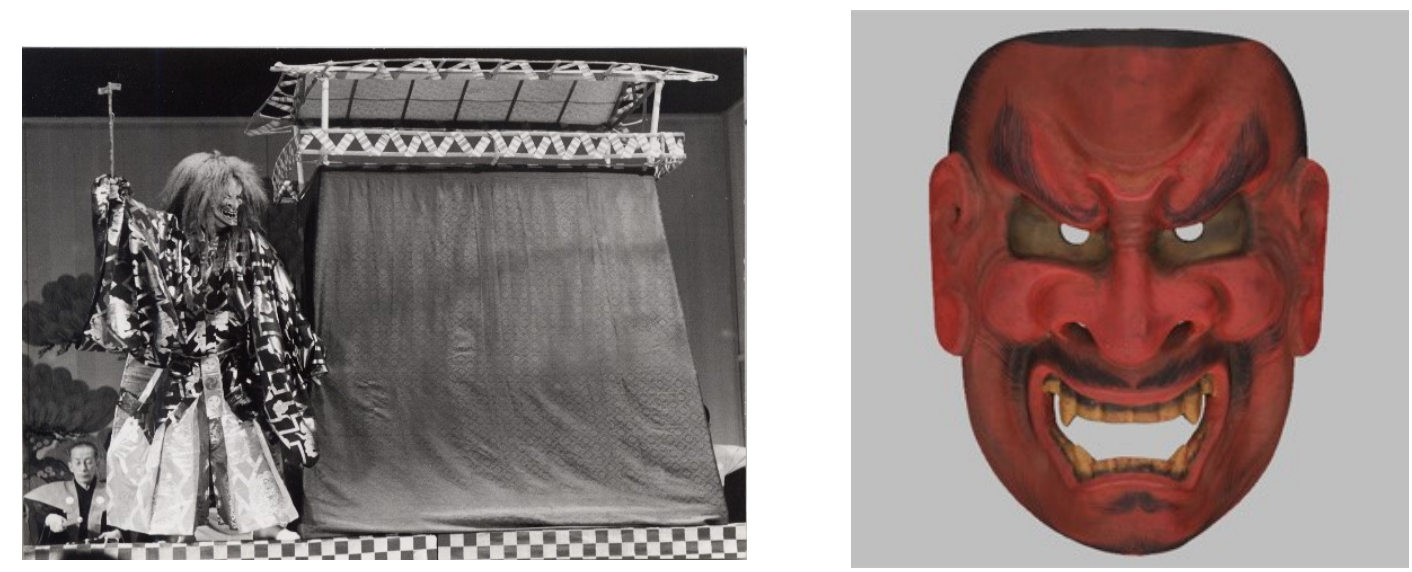

Figure 18. Rashomon. The shite actor as the demon in the second act. (Image courtesy of The Tsubouchi Memorial Theatre Museum, Waseda University, ID Number: F61-00688.)

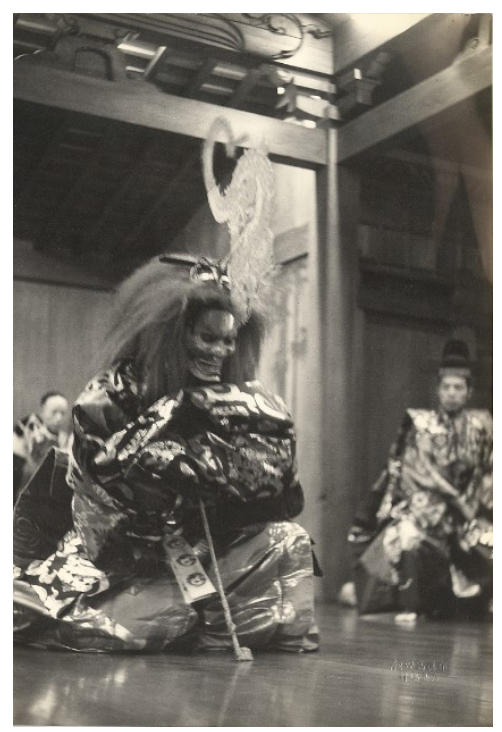

Figure 19. Shikami, violent demon mask, used in the second act of Rashomon. The same mask as in Momijigari. (Image courtesy of The Tsubouchi Memorial Theatre Museum, Waseda University, ID Number: 05639.)

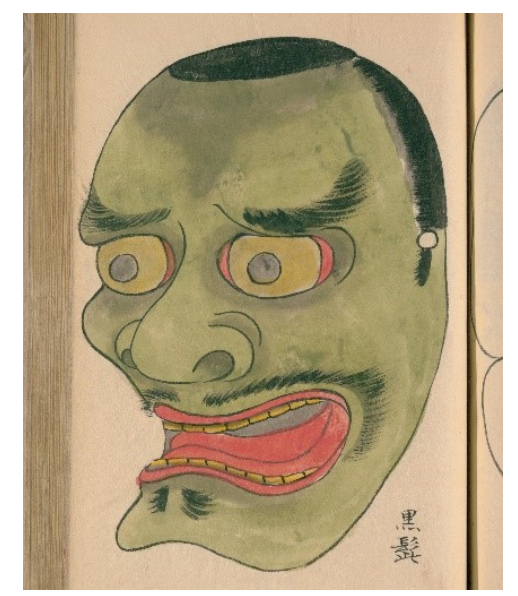

Figure 20. Orochi. The shite actor as the great serpent in the second act. (Image courtesy of The Tsubouchi Memorial Theatre Museum, Waseda University, ID Number: FA1-03270.)

Figure 21. Kurohige, black-beard mask, used in the second act of Orochi. In the picture book Nomen no $Z u$. (Image courtesy of National Diet Library Image Archives.) 


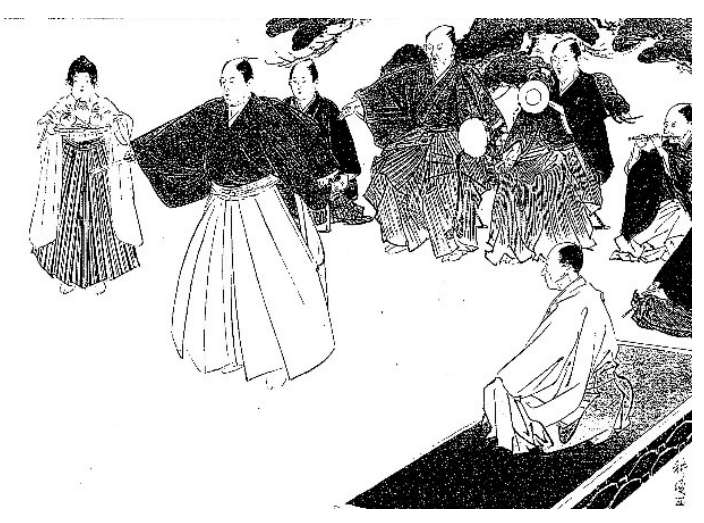

Figure 22. Musicians on stage in Tsukioka Kōgyo's picture book Nōgaku Zue, Japan, Matsuki Heikichi, 1899-1901. From the far right to left in the back, they are nōkan flute, kozutsumi drum, $\bar{o}$ tsuzumi drum, and taiko drum. (Image courtesy of National Diet Library Image Archives.) 